Sérgio Marcos Sanches

\title{
DETERMINAÇÃO DE SUBPRODUTOS CLORADOS FORMADOS DURANTE A ETAPA DE OXIDAÇÃO DA ÁGUA \\ CONTENDO SUBSTÂNCIAS HÚMICAS
}

Tese apresentada à Escola de Engenharia de São Carlos da Universidade de São Paulo, como parte dos requisitos do título de Doutor em Ciências da Encenharia Ambiental.

Orientadora: Prof Dr. Eny Maria Vieira

São Carlos

2005

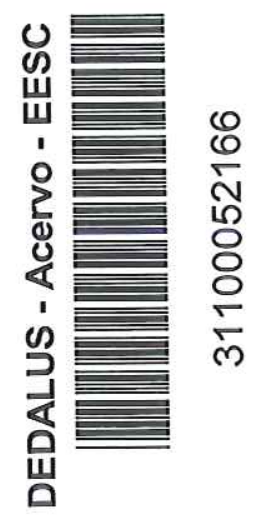


FOI,HA DE JU,GAMENTO

Candidata: Licenciado SERGIO MARCOS SANCHES

Tese defendida e julgada em 30-03-2005 perante a Comissão Julgadora:

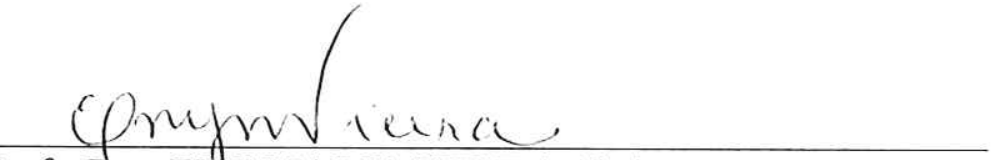

Profa. Dra. ENY MARIA VIEIRA (Orientadora)

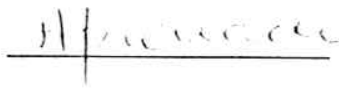

(Instituto de Química de São Carlos/EESC)

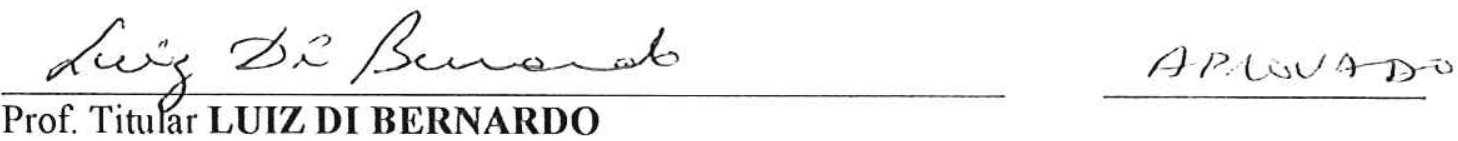

(Escola de Engepharia de São Carlos/EESC)

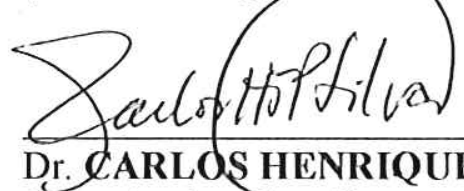

(Pesquisador FAPESP)

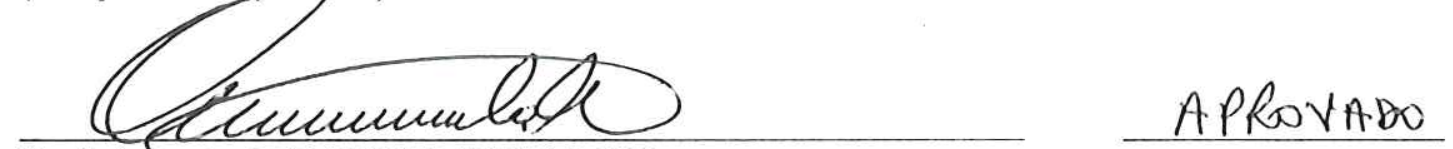

Prof. Associado VALDIR SCHALCH

(Escola de Engenharia de São Carlos/EESC)

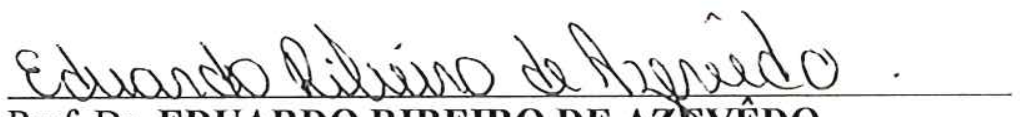

Prof. Dr. EDUARDO RIBEIRO DE AZEYÊDO

(Instituto de Física de São Carlos/USP)

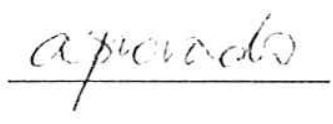

\section{Aprovado}

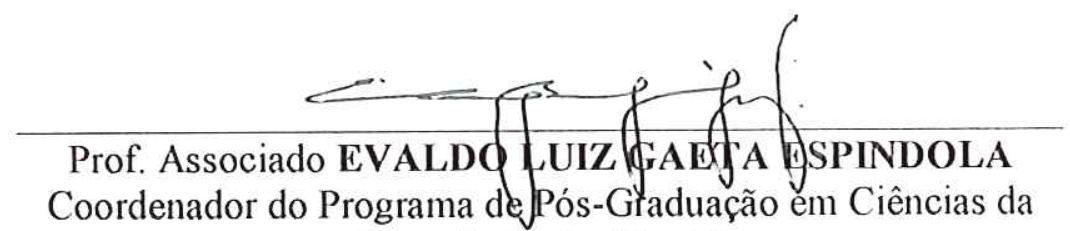

Engenharia Ambiental

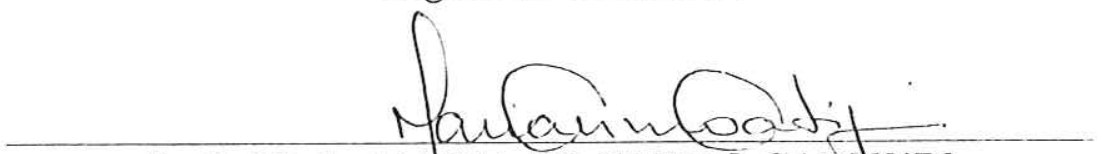

Profa. Tilular MARIA DO CARMO CAIIJURI

Presidente dalComissão de Pós-Graduação 
Neste dia, gostaria que estivesse presente alguém que amo muito, porém está ausente. A lembrança, no entanto, da sua presença, da sua voz, das nossas conversas, das coisas que fizemos, do seu abraço e da sua proteção, dos seus ensimamentos, dos jogos de futebol que vimos juntos, vêem a todo instante em minha memória, em um momento que fico cheio de saudades. Se hoje não posso the dar um forte abraço e aberto de mão, não me desespero, pois sei que o senhor meu pai está em um mundo melhor, pela pessoa integra, honesta batalhadora e bondosa que sempre foi. Pai, sei que o senhor deve estar muito feliz por ver o seu filho vencendo mais uma etapa em sua vida. Espero que sintas orgulho te seu filho. A morte significa apenas um passo, para a evolução das pessoas, porém os laços que nos unem, jamais serão rompidos.

Até qualquer dia....... 
Dedico este trabalho a minha esposa Célia Passos, a meu filho Serginho e a minha mãe Leonor Resende Vasconcelos, pelo companherismo, compreensão, carinho, afeto e ajuda no decorrer deste trabalho.

À vocês ofereço esta conquista com a mais profunda admiração e respeito. 


\section{AGRADECIMENTOS}

A Deus.

A Dra. Eny Maria Vieira pela orientação e amizade, além do apoio, do incentivo e da confiança sempre constantes, durante todos esse anos de convivência.

Ao Prof. Tit. Luiz Di Bernardo, do Departamento de Hidráulica e Saneamento - USP, pelo uso do laboratório, suporte financeiro e pelas inúmeras contribuições imprescindiveis, durante todo o desenvolvimento do trabalho.

A Professora Cristina Paschoalato da Unaerp, pela amizade, apoio, discussões e imprescindivel ajuda durante as análises dos subprodutos clorados.

A meus irmãos Toninho, Maria Antônia, Joana e sobrinhos pelo carinho, incentivo e amor demonstrados.

A meu cunhado luiz Nagy e cunhada Eloísa pelo incentivo.

A secretaria do Centro de Recursos Hidricos e Ecologia Aplicada, Claudete, pela amizade e atenção.

Aos técnicos do Instituto de Química, em especial a Renata, Fernando e Cidinha, pela ajuda e carinho demonstrado por minha pessoa.

Aos colegas de laboratório, Giovana, Marcelo, Sandro, Eleisy, Ricardo Reis, pela ajuda e amizade.

Aos amigos Marcelo (Bento), José Ricardo, Sandra, Guto e Carlos (carioca), Juvenal, Paulino e José Nelson pela amizade e descontrações ocorridas durante os churrascos.

Ao Bento e ao Marcio (Medi) pela ajuda na parte computacional.

Ao Daniel Pasquini e a Teresa pelo empréstimo de reagentes e uso das instalações do laboratório.

A dona Izabel (Zeza) e ao senhor José pela boa acolhida em sua casa.

Ao Prof. Valter e Aleida pelo carinho, ajuda e disposição.

Ao senhor Ademar Passos, dona Magnólia, Luciana e Renato pelo incentivo e carinho demonstrados.

Ao Júlio do Departamento de Hidráulica e Saneamento da USP, pelas análises e disposição sempre presentes. 
Ao Prof. Dr. Eduardo Ribeiro de Azevêdo pelas análises de ressonância magnética nuclear e aceite pela participação na banca.

Ao Prof. Assoc. Valdir Schalch pela amizade e aceite da participação na banca.

Ao pesquisador Carlos Henrique Tomich de Paula da Silva pelo aceite da participação na banca.

A Dra Maria Olímpia Rezende de Oliveira pelo uso do liofilizador.

A todas as pessoas que de certa forma me ajudaram durante o trascorrer deste trabalho.

À Capes pela bolsa e apoio financeiro concedidos. 


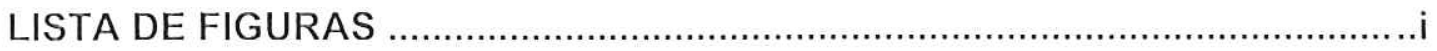

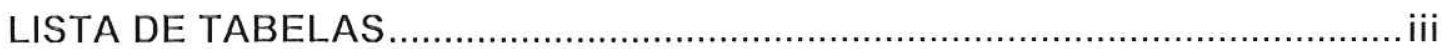

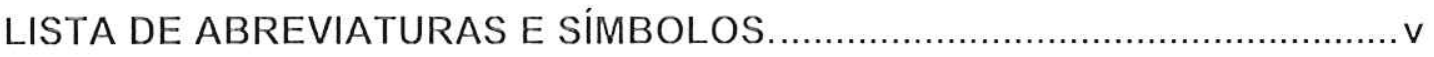

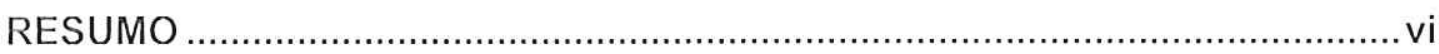

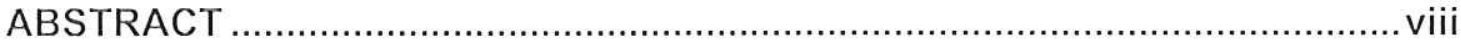

CAPÍTULO 1 - Extração, fracionamento e caracterização das substâncias húmicas

1 - INTRODUÇÃO

1.1 - Mecanismos propostos para a formação das substâncias húmicas ..... 3

1.2 - Estudo das estruturas das substâncias húmicas (SH) ......................... 5

1.3 - Principais métodos utilizados para a extração de (SH) ......................... 10

1.4 - Caracterização das substâncias húmicas .......................................... 10

1.4.1 - Espectroscopia no infravermelho com transformata de Fourier (FTIR)

1.4 .2 - Espectroscopia de fluorescência ........................................................ 12

1.4.3- Espectroscopia de absorção de luz no Visivel ................................... 12

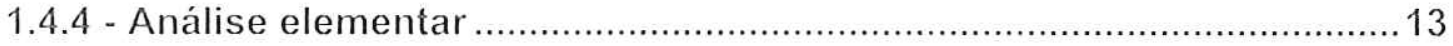

1.4 .5 - Ressonância magnética nuclear (RMN) ….................................. 13

1.4.6 -Espectroscopia de ressonância paramagnética eletrônica nuclear (EPR)

1.5 - OBJETIVOS

1.6.1.- Coleta e preparo das amostras .................................................. 16

1.6.2 - Extração das substâncias húmicas (SH) ......................................... 16

1.6.3 - Fracionamento das SH em diferentes tamanhos moleculares ............19

1.6 .4 - Liofilização das frações .................................................................. 20 
1.6.5 - Caracterização das frações das SH 20

1.6.5.1 - Espectroscopia de infravermelho com transformada de Fourier (FTIR)

1.6.5.2 - Espectroscopia na região do visível razão $E_{4} / E_{6}$

1.6.5.3 - Análise elementar

1.6.5.4 - Análises de ressonância paramagnética eletrônica (EPR)

1.6.5.5- Análise de ressonância magnética nuclear de $C^{13}$ em estado

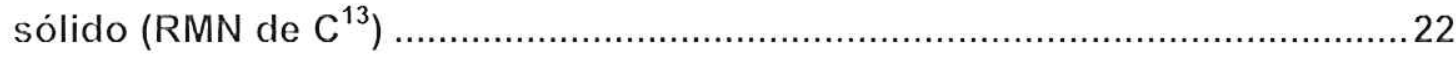

1.6.5.6 - Determinação da acidez carboxílica, fenólica e total ....................... 23

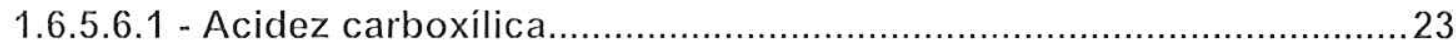

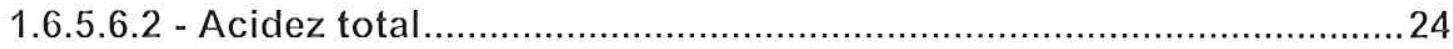

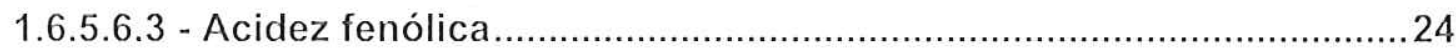

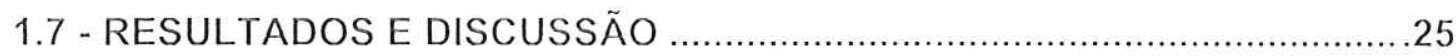

1.7.1 -Análise espectroscópica por infravermelho com transformata de

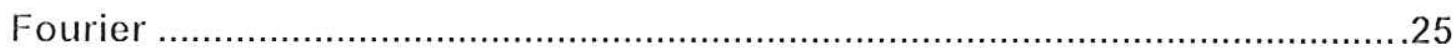

1.7.2 - Análise espectroscópica na região do visivel (razão $E_{4} / E_{6}$ )...............27

1.7 .3 - Ressonância magnética nuclear de $\mathrm{C}^{13} \mathrm{em}$ estado sólido

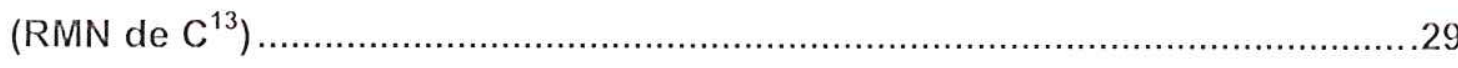

1.7.4 - Ressonância paramagnética nuclear (EPR) .................................. 31

1.7 .5 - Análise elementar.................................................................... 34

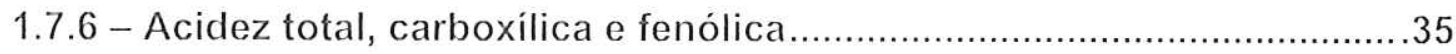

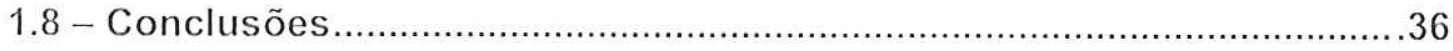

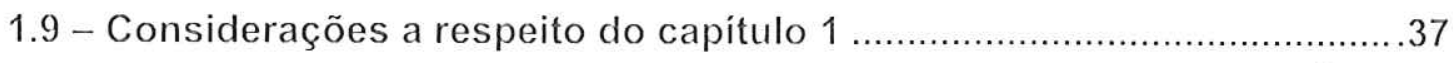

CAPÍTULO 2 - Ensaios de demanda com os oxidantes cloro e dióxido de cloro

2 - INTRODUÇÃO.

2.1 - Evolução dos processos de cloração da água e uso de agentes

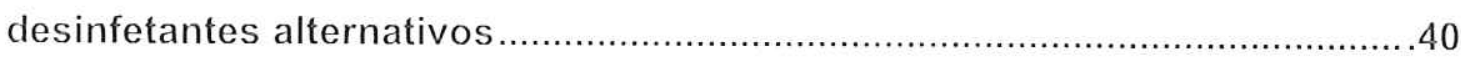
2.1.1 -Evolução dos processos de cloração da água 
2.1.2 - Processo de cloração nas estações de tratamento de água (ETA)....41

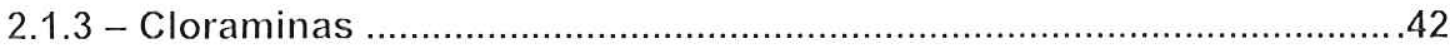

2.1.4 - Uso de desinfetantes alternativos ...............................................44

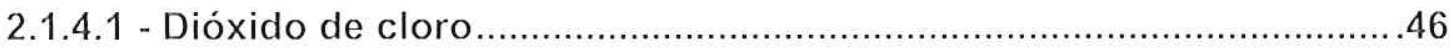

2.1.4.2 - Permanganato de potássio ...................................................46

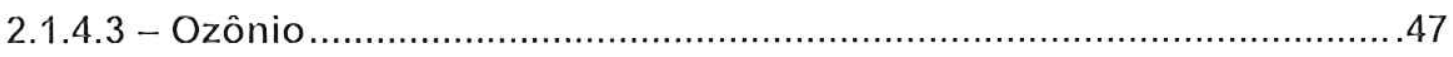

2.1.4.4 - Peróxido de Hidrogênio .......................................................... 48

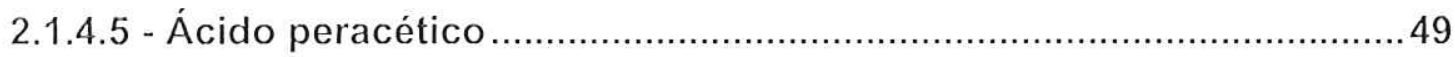

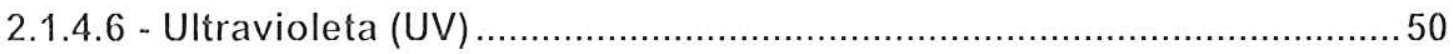

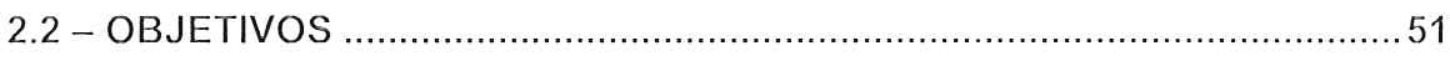

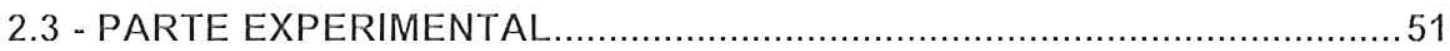

2.3.1 - Construção da curva de calibração de cor em relação ao $\mathrm{pH}$.............51

2.3.4 - Característica da água utilizada nos ensaios de pré-oxidação ............53

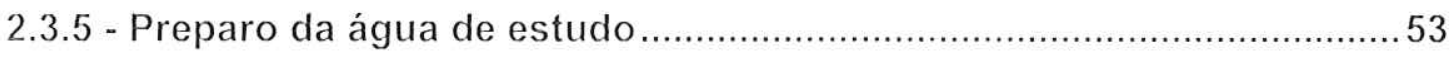

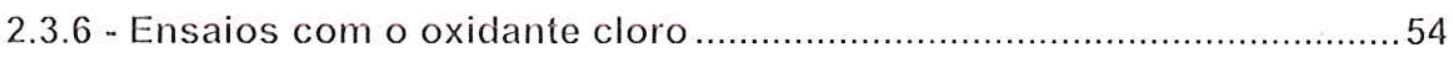

2.3.6.1- Solução de cloro utilizada no ensaio ........................................... 54

2.3.6.2 - Ensaios de demanda com o oxidante cloro …...............................54

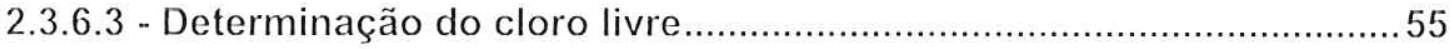

2.3.7 - Ensaios com o oxidante dióxido de cloro ......................................... 56

2.3.7.1 - Obtenção do dióxido de cloro ......................................................... 56

2.3.7.2 - Determinação da demanda e residual de dióxido de cloro ...............57

2.4 - RESULTADOS E DISCUSSÃO.

2.4.1 - Ensaios para determinar a concentração de dióxido de cloro "demanda de dióxido de cloro" a serem utilizadas nos ensaios de formação dos subprodutos clorados

2.4 .2 - Ensaios para determinar a concentração de cloro "demanda de cloro" a serem utilizadas nos ensaios de formação dos subprodutos clorados 
CAPÍTULO 3 - Validação do método analítico utilizado para a determinação dos subprodutos da oxidação

3 - INTRODUÇÃO. 70

3.1 - Critérios de validação. .71

3.11 - Especificidade e seletividade 71

3.1.2 - Limite de deteç̧ão .72

3.1.3 - Limite de quantificação .73

3.1.4 - Curva analítica .74

3.1.5 - Intervalo de trabalho .74

3.1.6 - Linearidade .75

3.1.7 - Exatidão .75

1.3.5 - Precisão .76

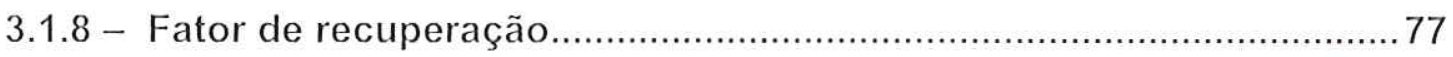

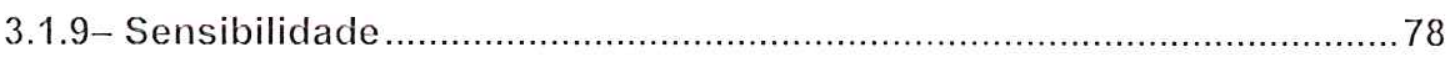

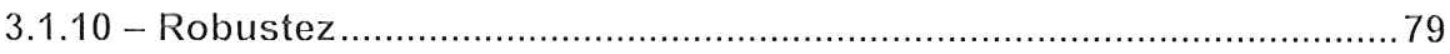

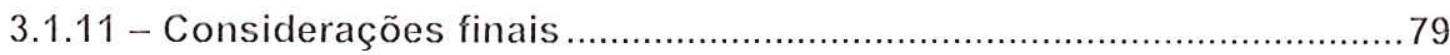

3.2.1 - Validação do método de extração e determinação de trialometanos, halocetonas, haloaldéidos e halopicrinas por cromatografia em fase gasosa com deteç̧ão por captura de elétrons (DCE) …………………........ 80

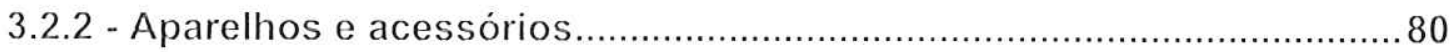

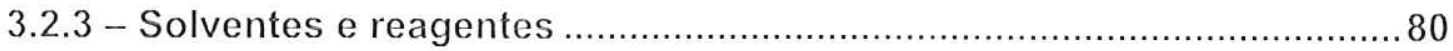

3.2.5 - Validação do método para determinação de subprodutos clorados

3.2.5.1- Condições cromatográficas otimizadas para análise dos subprodutos da oxidação 81

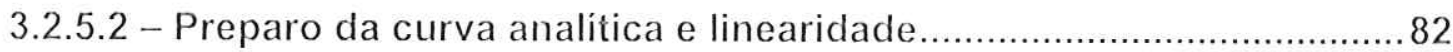

3.2.5.3 - Precisão e recuperação 
3.3.1 - Otimização das condições cromatográficas para a determinação de subprodutos clorados 83 3.3.2 - Estudo da linearidade e da resposta do detector de captura de elétrons 84

3.3.3 - Exatidão e recuperação do método 91

3.4 - Conclusões. 93

3.5 - Considerações a respeito do capítulo 3 .

CAPÍTULO 4 - Determinação dos subprodutos formados durante a oxidação da água, contendo substâncias, com os oxidantes cloro e dióxido de cloro.

4 - INTRODUÇÃO 94

4.1 - REVISÄO BIBLIOGRÁFICA 96

4.1.1 - Trialometanos 96

4-1.2 - Fontes de exposição 97

4.1-3 - Carcinogenicidade 97

4.1.4 - Aplicação de um valor guia 98

4.1.5 - Fatores que influenciam a formação de trialometanos 100

4.1.5.1 - Tempo de contato. 100

4.1.5.2 - Temperatura 100

4.1.5.3 - Efeito da concentração de brometo e iodeto na formação de subprodutos clorados 101

4.1.5.4 - Aumento do $\mathrm{pH}$

4.1.5.5 - Efeito da concentração dos precursores na formação de subproduos clorados

4.1.6 - Principais mecanismos propostos para a formação de cloróformio e outros trialometanos 102

4.1.7 - Controle de trialometanos no processo de tratamento de água 104 
4.1.7.1 - Tratamento para reduzir a concentração dos precursores antes

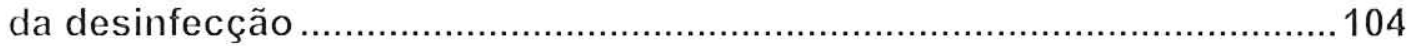

4.1.7.2 - Carvão ativado em pó................................................................... 105

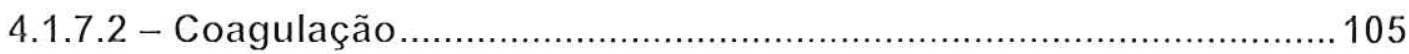

4.1.7.3 - Tratamento para remoção de THM depois de formados ..............106

4.1.7. 4 -Processos alternativos de desinfecção ................................... 106

4.1.8 -Técnica utilizada para identificação de trialometanos e de subprodutos clorados ....................................................................... 107

4.1.8.1 - Cromatografia gasosa ............................................................ 107

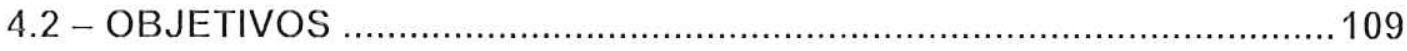

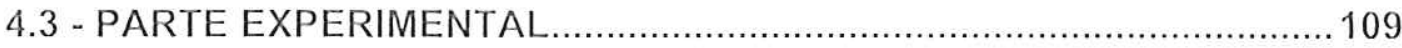

4.3.1 - Ensaios de oxidação e determinação dos subprodutos clorados 109

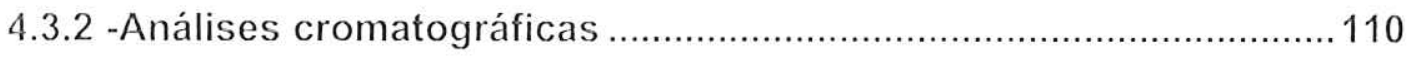

4.4 - RESULTADOS E DISCUSSÃO.

4.4.1 - Determinação de subprodutos clorados formados durante a etapa de pré-oxidação da água contendo SH com o oxidante cloro 111 4.4 .2 - Determinação de subprodutos clorados formados durante a etapa de pré-oxidação da água contendo SH com o oxidante dióxido de cloro. 118

4.5 - Conclusões

CAPITULO - 5 Conclusões gerais e propostas de trabalhos futuros

5.1 - Conclusões gerais 123

5.2 - Propostas para trabalhos futuros 124

CAPITTULO - 6 Referências bibliográficas. 125 


\section{LISTA DE FIGURAS}

Figura 1 - Principais vias propostas para a formação das substâncias húmicas pela decomposição de residuos animais/vegetais no solo

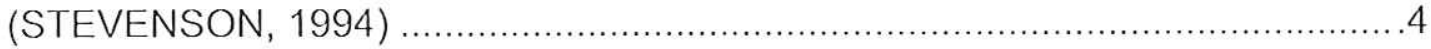

Figura 2 - Proposta de estrutura para AF por Schnitzer e Khan (1978) .............6

Figura 3 - Estrutura planar dos ácidos húmicos Schulten e Schnitzer (1997) .....7

Figura 4 - Estrutura proposta para o ácido húmico Sein Junior et al.(1999) .......8

Figura 5 - Esquema de estabilização do radical semiquinona (SCHITZER, 1990).

Figura 6- Fluxograma das etapas envolvidas na extração e purificação das SH.18 Figura 7- Foto do equipamento de ultrafracionamento ( vivaflow 50) (CAMPOS, 2004)

Figura 8- Espectros de IV para as frações das SH. 25

Figura 9 - Espectros de RMN CP/MAS de ${ }^{13} \mathrm{C}$ para as fraçōes das SH 29

Figura 10 - Espectro de EPR para a fração de $0,45 \mu \mathrm{m}$

Figura 11- Espectro de EPR do radical livre semiquinona para a fração de $0,45 \mu \mathrm{m}$

Figura 12- Radical livre semiquinona

Figura 13 - Curva de calibração de cor das substâncias húmicas para pH 6,5 ...52

Figura 14 - Curva de calibração de cor das substâncias húmicas para $\mathrm{pH} 7,0 \ldots 52$

Figura 15 - Equipamento de jartest que foi utilizado nos ensaios de oxidação (Carvalho, 2003)

Figura 16 - Gerador de dióxido de cloro modelo Bello Zon® CDVa (CARVALHO, 2003)

Figura 17- Variação do residual de $\mathrm{ClO}_{2}$ em função da dosagem do oxidante, água do ensaio preparada com a fraçäo de SH de tamanho molecular entre $0-45 \mu \mathrm{m}$

Figura 18 - Demanda de $\mathrm{ClO}_{2}$ em função da dosagem do oxidante, água preparada com a fração de tamanho molecular entre 0- $45 \mu \mathrm{m}$ 60

Figura 19 - Residual de cloro versus dosagem de cloro 65

Figura 20 - Demanda de cloro versus dosagem aplicada do oxidante na água preparada com SH de tamanho molecular 0,45 $\mu \mathrm{m}$ 65 
Figura 21 - Cromatograma do branco analitico 83

Figura 22 - Cromatograma da curva de calibração com $50 \mu \mathrm{g} \mathrm{L}^{-1} \ldots \ldots \ldots \ldots \ldots \ldots \ldots . . . . . . . . .84$

Figura 23- Curva analitica obtida para o clorofórmio. 85

Figura 24 - Curva analitica obtida para a 1,1,1-tricloropropanona 85

Figura 25 - Curva analitica obtida para a tricloroacetonitrila 86

Figura 26 - Estrutura molecular dos quatro THM principais 97

Figura 27 - Efeito da temperatura na formaçăo de THM Stevens et al. (1997) ... 101

Figura 28 - Influência do pH na formação dos THM Symons et al. (1981) ........... 102

Figura 29 - Possivel mecanismo de formação de THM. 103

Figura 30 - Prováveis estruturas moleculares responsáveis pela formação de clorofórmio (MACÊDO, 1997) 103

Figura 31 - Curva analitica para o clorofórmio 110

Figura 32 - Estrutura do tipo resorcinol 111

Figura 33 - Mecanismo de formação do clorofórmio a partir da estrutura do tipo resorcinol

Figura 34 - Formação dos subprodutos da oxidação em função do tempo de reação, utilizando-se uma dosagem de $7,0 \mathrm{mg} \mathrm{L}^{-1}$ de cloro, cuja água foi preparada com SH filtrada em filtro $0,45 \mu \mathrm{m}$

Figura 35 - Formação de clorofórmio em função do tamanho molecular das frações das SH utilizando-se a dosagem de 7,0 $\mathrm{mg} \mathrm{L}^{-1}$ de cloro 


\section{LISTA DE TABELAS}

Tabela 1 - Principais picos atribuidos às substâncias húmicas (SH).

Tabela 2 - Principais bandas observadas na região do infravermelho nas substâncias húmicas e suas possivéis atribuições Ricca et al. (2000)

Tabela 3 - Valores das absorbâncias em 465 e 665 nm e valores da razão $E_{4} / E_{6}$

Tabela 4 - Valor da quantidade de radicais livres semiquinonas por massa (g) de cada fração

Tabela 5 - Composição elementar das fraçöes de diferentes tamanhos moleculares das $\mathrm{SH}$ e as razōes atômicas dos elementos 34 Tabela 6 - Caracterização química das frações das SH com base em grupos funcionais.

Tabela 7 -Características físicas e químicas da água do poço artesiano da Escola de Engenharia de São Carlos utilizada na preparação da água de estudo

Tabela 8 - ensaios de pré-oxidação com dióxido de cloro, cuja água foi

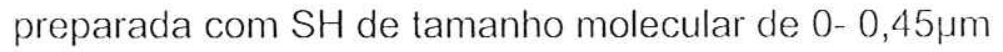
58

Tabela 9 - Ensaios de demanda realizados com concentrações do oxidante dióxido de cloro de 0,25 a $2,0 \mathrm{mg} \mathrm{L}^{-1}$, água preparada com substâncias húmicas de tamanho molecular entre 30-100 KDa

Tabela 10 - Ensaios de demanda realizados com concentrações do oxidante dióxido de cloro de 0,25 a $2,0 \mathrm{mg} \mathrm{L}^{-1}$, água preparada com substâncias húmicas de tamanho molecular maior do que $100 \mathrm{KDa}$

Tabela 11 - Ensaios de pré-oxidação com o cloro, cuja água foi preparada com $\mathrm{SH}$ de tamanho molecular de $0-0,45 \mu \mathrm{m}$

Tabela 12 - Ensaios de pré-oxidação com o cloro, cuja água foi preparada com SH de tamanho molecular maior do que $100 \mathrm{KDa}$....

Tabela 13- ensaios de pré-oxidação com o cloro, cuja água foi preparada com SH de tamanho molecular no intervalo de 30-100 KDa 68 Tabela 14 - Coeficientes de correlaçōes e equações das retas obtidas para os subprodutos clorados 
Tabela 15 - Resultados do estudo da precisão do método para a determinação de subprodutos clorados..... .88

Tabela 16 - Coeficientes de variação em função do nivel de concentração do analito (WOOD, 1999) 90

Tabela 17 - Valores de porcentagem de recuperação dos trialometanos e outros subprodutos clorados. .92

Tabela 18 - Subprodutos da oxidação formados durante a oxidação de uma água contendo $\mathrm{SH}$ filtrada em filtro $0,45 \mu \mathrm{m}$, utilizando-se a dosagem do oxidante cloro de $7,0 \mathrm{mg} \mathrm{L}^{-1}$

Tabela 19- Subprodutos da pré-oxidação formados durante a oxidação de uma água contendo SH de tamanho molecular ente 30-100 KDa, utilizando-se 7,0 $\mathrm{mg} \mathrm{L}^{-1}$ de cloro.. 116

Tabela 20 - Subprodutos da oxidação formados durante a pré-oxidação de uma água contendo SH de tamanho molecular maior do que $100 \mathrm{KDa}$, utilizando-se $7,0 \mathrm{mg} \mathrm{L}^{-1}$ do oxidante cloro 116

Tabela 21- Subprodutos da oxidação formados durante a pré-oxidação de uma água contendo SH de tamanho molecular ente 30-100 KDa, utilizando-se a dosagem de $1,0 \mathrm{mg} \mathrm{L}^{-1}$ de dióxido de cloro 120 Tabela 22- Determinação de subprodutos da oxidação formados durante a etapa de pré-oxidação da água contendo fração da SH de tamanho molecular entre $30-100 \mathrm{KDa}$, utilizando-se a dosagem de 1,0 $\mathrm{mg} \mathrm{L}^{-1}$ de dióxido de cloro 120 


\section{LISTA DE ABREVIATURAS E SIMBOLOS}

AH - Ácido húmico

AF - Ácido fúlvico

CF - Clorofórmio

CP/MAS - Polarização cruzada/ rotação da mostra em torno do ângulo mágico EPR - Ressonância paramagnética eletrônica

ETA - Estação de tratamento de água

FTIR - Transformada de Fourier

IV - Infravermelho

KDa - Quilo Dalton

MON - Matéria orgânica natural

RMN - Ressonância magnética nuclear

SH - Substâncias húmicas

SPD - Subprodutos da oxidação

THM - Trialometanos

UH - Unidade Hazen Pt- Co/L

Vis - Visivel

UF- UItrafiltração 


\section{RESUMO}

SANCHES, S. M. (2005). Determinação de subprodutos clorados formados durante a etapa de oxidação da água contendo substancias húmicas. São Carlos, 2005. 134p. Tese (Doutorado) - Escola de Engenharia de São Carlos, Universidade de São Paulo.

No Brasil, a desinfecção e oxidação da água, para o consumo humano, são usualmente realizadas com a adição de cloro nas formas de gás cloro e hipoclorito de sódio. Estudos recentes tem demonstrado que a oxidação e desinfecção da água com o cloro podem ocasionar a formação de trialometanos e outros subprodutos clorados. Alguns destes subprodutos são substâncias carcinogênicas. Neste trabalho estudou-se a influência das substâncias húmicas (SH) extraidas da turfa, com diferentes massas moleculares, na formação de trialometanos e outros subprodutos clorados em decorrência do uso do cloro e dióxido de cloro na etapa de oxidação da água. As frações das $\mathrm{SH}$ utilizadas neste trabalho foram caracterizadas por análise elementar, ultravioleta visivel, ressonância magnética nuclear de $\mathrm{C}^{13}$ (RMN de $\mathrm{C}^{13}$ ), ressonância paramagnética nuclear eletrônica (EPR) e infravermelho. Estas caracterizações demonstraram que a fração de menor massa molecular (30-100 KDa), obtidas por ultrafiltração (UF), apresentou um menor grau de condensação de grupamentos aromáticos em relação as frações de SH de massa molecular menor que $0,45 \mu \mathrm{m}$ e maior do que $100 \mathrm{KDa}$. Nas análises realizadas por RMN de $\mathrm{C}^{13}$ e análise elementar, constatou-se que a fração de SH de massa molecular entre 30-100 KDa, apresentou uma maior porcentagem de grupos contendo oxigênio. Após as caracterizaçōes das SH, preparou-se três tipos de água, com cor $100 \pm 5$ $u H$, adicionando-se as diferentes fraçöes de SH na àgua separadamente. A seguir foram realizados ensaios no equipamento jarteste, para a determinação das dosagens dos oxidantes cloro e dióxido de cloro os quais foram utilizadas nos ensaios de formação dos subprodutos clorados. Estes ensaios foram realizados variando-se as dosagens do 
oxidante em função do tempo de reação. As concentrações dos oxidantes determinadas foram de $7,0 \mathrm{mg} \mathrm{L}^{-1}$ para o cloro e de $1,0 \mathrm{mg} \mathrm{L}^{-1}$ para o dióxido de cloro. Na realizaçăo dos ensaios de formação dos subprodutos clorados, considerou-se o tempo de reação em função da dosagem dos oxidantes cloro e dióxido de cloro que foram determinadas anteriormente nos ensaios de demanda. Os subprodutos clorados, formados, foram quantificados utilizando-se a técnica de cromatografia gasosa com detector de captura de elétrons. O método utilizado foi o do padrão interno. O clorofórmio foi o subproduto majoritário, nos ensaios realizados com todas as frações. Na oxidação da água com o cloro, ocorreu a formação de um maior número de subprodutos clorados em relação aos ensaios realizados com oxidante dióxido de cloro. Nos ensaios realizados com a água preparada com SH de menor tamanho molecular ocorreu uma maior concentração dos subprodutos clorados formados, especialmente para o clorofórmio. 


\section{ABSTRACT}

SANCHES, S.M. (2005). Determination of chlorine by-products wich have been formed during the water oxidation step with humic substances. São Carlos, 2005. 135p. Tese (Doutorado) - Escola de Engenharia de São Carlos, Universidade de São Paulo.

In Brazil, the disinfection and oxidation of drinking water is usually done by the addition of chlorine in the chlorine gas and sodium hypochloride forms. Recent studies have demonstrated that disinfection and oxidation of water using chlorine can cause the formation of trihalomethane and others chlorine by-products, which are carcinogenic substances. In this present work, it has been studied the influence of the humic substance (SH) extracted from peat soil, with different molecular size, in the formation of trihalomethane and others chlorine by-products as results of the use of chlorine and chlorine dioxide in the water oxidation step. The $\mathrm{SH}$ fractions used in this work were characterized by elemental analysis, visible ultraviolet, $C^{13}$ nuclear magnetic resonance $\left(C^{13} N M R\right)$, electron paramagnetic resonance (EPR) and infrared spectroscopy. Such characterization showed that the fractions with smaller molecular size (30-100 KDa), obtained by ultrafiltration (UF), presented a smaller degree of aromatic groups condensation with respect to fractions of $\mathrm{SH}$ molecular size smaller than $0,45 \mu \mathrm{m}$ and higher than $100 \mathrm{KDa} . \mathrm{C}^{13} \mathrm{NMR}$ and elemental analysis were also used. SH fraction of molecular size between 30-100 KDa presented higher percentage of groups containing oxygen. After characterizations of $\mathrm{SH}$, water was prepared with $100 \pm 5$ uH color, with separated addition of different fractions of $\mathrm{SH}$ in the water. Tests in the jarteste equipment were realized for the determination of dosages of chlorine and chlorine dioxide oxidants, which were utilized in the test of formation of chlorine by-products. These tests were perforrmed studying the oxidant dosage in function of the reaction time. The oxidant concentrations were $7.0 \mathrm{mg} \mathrm{L}^{-1}$ for the chlorine and $1.0 \mathrm{mg} \mathrm{L}^{-1}$ for chlorine dioxide. Formation of chlorine by-products was tested considering the reaction of time with respect to the oxidants dosage of chlorine and oxidant chlorine, previously determined. The chlorine by-products resultant 
were quantified using the gas chromatography with detector of electron capture technique GC-ECD. The method utilized was the addition of internal standard. In the water oxidation by chlorine an higher number of chlorine by-products occurred in comparison of the test performed with chlorine dioxide. In the test performed with the water prepared with $\mathrm{SH}$ of smallest molecular size a highest concentration of resultant by-products occurred, specially by chloroform.

Keywords: humic substances, by-products, oxidation, Chlorine, oxide chlorine. 


\section{Considerações iniciais}

Este trabalho foi dividido em seis capitulos os quais encontram-se apresentados na Figura a seguir:

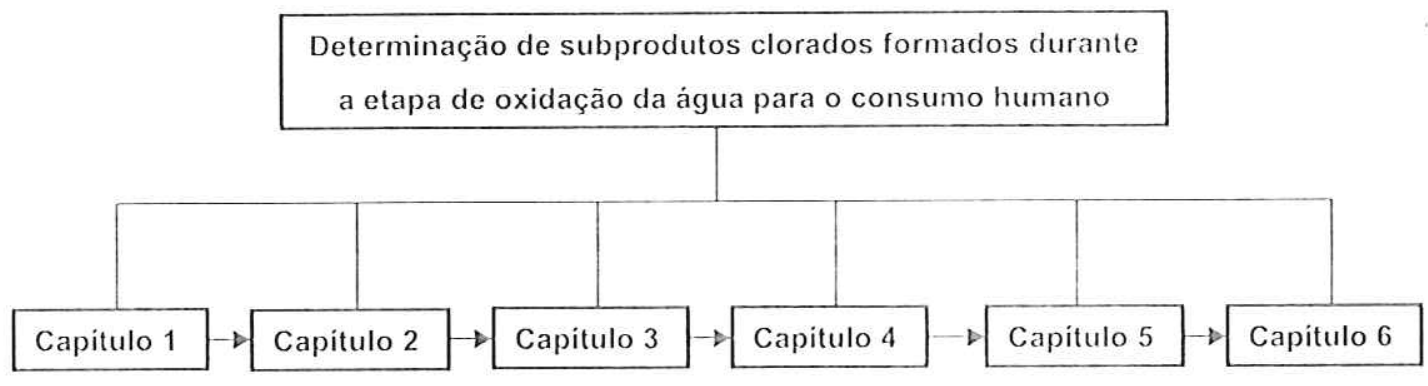

\section{Legenda:}

Capítulo 1 - Extração, fracionamento e caracterização das substâncias húmicas.

Capitulo 2 - Ensaios de demanda com os oxidantes cloro e dióxido de cloro.

Capítulo 3 - Validação do método analítico.

Capitulo 4 - Determinação dos subprodutos da oxidação.

Capítulo 5 - Conclusões gerais e recomendações para trabalhos futuros.

Capitulo 6 - Referências bibliográficas

No capitulo 1 foi avaliada as caracteristicas e propriedades estruturais das frações das substâncias húmicas $(\mathrm{SH})$. As frações das SH foram utilizadas no preparo das águas utilizadas nos ensaios de demanda, capitulo 2, e também utilizadas na determinação dos subprodutos clorados, capitulo 4.

A caracterização das $\mathrm{SH}$ foi realizada com a finalidade de identificar grupos funcionais presentes na estrutura, que poderiam reagir com o cloro e dioxido de cloro, visto que os mecanismos propostos para formação de subprodutos da oxidação sugerem que a reação dos oxidantes cloro e dióxido de cloro ocorre devido a interação destes com os grupos carboxilicos e a estrutura resorcinol.

Para determinar os subprodutos formados, capitulo 4, teve-se inicialmente determinar as concentrações de cloro e dióxido de cloro a serem utilizadas nos 
ensaios de oxidação da água contendo frações das SH. As concentrações dos oxidantes foram determinadas nos ensaios de demanda, capítulo 2.

Na determinação dos subprodutos clorados formados, foi utilizada a técnica de cromatografia gasosa, cujo método foi desenvolvido e validado no capítulo 3 . No capitulo 5 foram feitas as conclusões gerais do trabalho, e no capitulo 6 , recomendações para trabalhos futuros.

\section{Considerações a respeito do trabalho}

Para se determinar os subprodutos clorados formados durante a etapa de oxidação da água com o cloro e dióxido de cloro, não basta somente identificar e quantificar os subprodutos formados e sim identificar também a causa da formação dos subprodutos. Para isso, torna-se imprescindivel o inter-relacionamento entre áreas distintas, como a engenharia, que detém o conhecimento em relação às técnicas de tratamento de água, e a química, que pode contribuir com os conceitos e ferramentas analiticas que ajudam a entender melhor os processos envolvidos.

No caso deste trabalho, esta interdisciplinaridade foi importante pois, procurou-se verificar a influência do tamanho molecular das SH na formação dos subprodutos da oxidação, visto que na literatura existem trabalhos referentes à formação dos subprodutos da oxidação, porém há poucos trabalhos levando-se em conta o tamanho molecular das SH na formação dos subprodutos da oxidação. Desta forma, acredita-se que este trabalho, muito contribuirá para a área de saneamento. 


\section{CAPITULO - 1}

Extração, fracionamento e caracterização das substâncias húmicas

\section{1- INTRODUÇÃO}

A matéria orgânica (MO) encontra-se presente no solo como conseqüência da atividade dos seres vivos. Ela é constituida pela mistura de microrganismos e restos de vegetais e de animais que, em decorrência da degradação química e biológica, encontram-se em vários estágios de decomposição (STEVENSON, 1994). Desta forma o termo MO do solo é geralmente usado para representar os constituintes orgânicos do mesmo, incluindo residuos de plantas e animais, seus produtos parciais de decomposição, e a sintese de novas substâncias realizada pela população microbiana do solo (STEVENSON, 1994; VIEIRA, 1996). Ela contém compostos que podem ser convenientemente agrupados em substâncias não-húmicas e húmicas. Quimicamente bem definidas as substâncias não-húmicas, ou compostos lábeis, consistem em ácidos alifáticos e aromáticos, carboidratos, aminoácidos e seus derivados poliméricos como polipeptideos, proteinas, polissacarideos e lipideos (SCHINITZER, 1991). Essas substâncias são facilmente atacadas por microrganismos e, com isso sua vida é relativamente curta.

Já as substâncias húmicas representam cerca de 2/3 do carbono orgânico do solo. Apresentam uma estrutura quimica complexa, são amorfas, de cor escura, hidrofilicas, parcialmente aromáticas, e suas massas moleculares variam desde poucas centenas a milhares de unidades de massa atômica, Schinitzer e Khan (1972).

Cerca de 10 a $15 \%$ da reserva total do carbono orgânico nos solos minerais é constituida por macromoléculas (proteinas e aminoácidos, carboidratos simples e complexos, resinas, ligninas e outros), e de 85 a 90\% pelas SH onde destacam os ácidos fúlvicos, húmicos e humina como as três fraçōes principais do carbono 
Capitulo 1

total do solo, sendo a humina representada por cerca de 30 a $80 \%$. Guerra e Santos (1999)

As SH são substâncias orgânicas naturais encontradas em águas, solos e sedimentos e são constituídas de uma mistura heterogênea de compostos, onde cada fração (ácidos húmicos, ácidos fúlvicos e humina) possuem uma série de moléculas de tamanhos moleculares diferentes com a maioria não apresentando a mesma configuração estrutural ou grupos reativos na mesma posição (FALONE, 2004; FUKUSHIMA, 1996; JANOS, 2002). Os ácidos húmicos (AH) são a fração das substâncias húmicas solúvel em meio alcalino e insolúvel em meio ácido. Os ácidos fúlvicos permanecem em solução quando o meio é acidificado e a humina é a fração insolúvel tanto em álcali como em ácido (SCHINITZER, 1991).

Esta clássica definição para as $\mathrm{SH}$, relacionando suas propriedades com a solubilidade, é bastante aceita mas o limite dessa divisão não é ainda claramente definido em termos químicos. Na metade do século 20, (KONONOVA, 1966) apresentou uma revisão colocando algumas hipóteses, e estas introduzem o conceito de SH como sendo uma molécula polimérica.

A distribuição das frações ácidos fúlvicos, ácidos húmicos e huminas em função das condições ambientais foi estudada por alguns autores (KONONOVA, 1966). Segundo Vaughan e Ord (1985) a importância das fraçōes húmicas na dinâmica dos elementos no solo estende-se também às interações com os fertilizantes, podendo aumentar ou reduzir sua efetividade, além de corrigir os efeitos negativos causados pelas altas doses empregadas, regulando desta forma, as condições de nutrição mineral das plantas. A quantidade e a proporção com que estas frações são encontradas nos solos tem servido como indicador da qualidade dos mesmos, devido a interação dessas substâncias com o material mineral presente nestes.

As substâncias húmicas (SH) são de fundamental importância para o crescimento de plantas e para o controle bioquimico do carbono orgánico no ecossistema Piccolo et al. (1966). Elas interagem com o material mineral presente no solo, interferindo, assim, na dinâmica de nutrientes no sistema solo-planta, e exercendo um papel primordial na manutenção da fertilidade do solo; termo cujo o 
conceito global se estende também às propriedades físicas e biológicas Rocha e Rosa (2003). As SH desempenham um importante papel no ambiente, uma vez que regulam quase todas os processos que ocorrem no solo. Para entender tais processos torna-se necessário obter informações sobre a sua estrutura.

\section{1 - Mecanismos propostos para a formação das substâncias húmicas}

A determinação da estrutura das $\mathrm{SH}$ bem como a bioquímica de sua formação constituem ainda hoje, apesar de vários estudos na área, um dos aspectos pouco compreendidos da química do húmus. Entre estes estudos destaca-se os realizados por (Kononova,1966; Schnitzer 1978). Na Figura 1 encontra-se apresentado pelo menos quatro vias principais de formação de SH durante a decomposição de residuos nos solos (STEVENSON, 1994). O principal processo é a oxidação de substratos hidrolisados monoméricos, para conduzir a polimeros macromoleculares de cor mais ou menos escura e massa molecular elevada. 


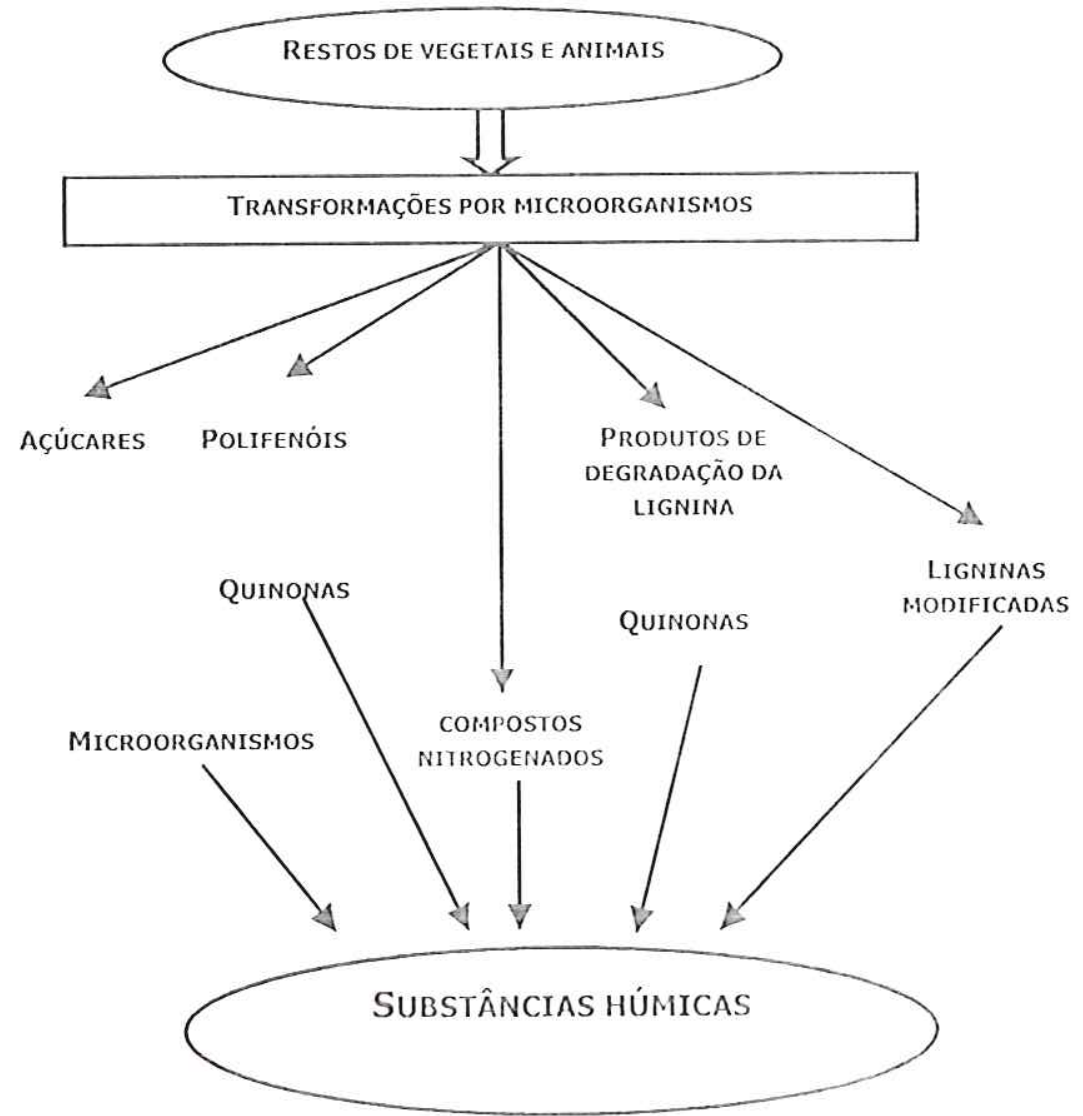

Figura 1 - Principais vias propostas para a formação das substâncias húmicas pela decomposição de resíduos animais/vegetais no solo (STEVENSON, 1994).

O mecanismo 1 propõe a formação do húmus a partir da polimerização não enzimática por condensação entre aminoácidos e açucares formados como subprodutos da atividade microbiana. Os mecanismos 2 e 3 envolvem a participação de quinonas e, no mecanismo 4 representando a teoria clássica, as $\mathrm{SH}$ seriam derivadas de ligninas modificadas. (MALCOM, 1990) afirma que a lignina não é o principal precursor de $\mathrm{SH}$ de solo. Além disso, mostra que há grandes diferenças estruturais em substâncias de diferentes origens, como solo, rios e mar (MALCOM, 1990). Os mecanismos baseados na condensação polimerica de polifenóis e quinonas têm sido os mais aceitos por pesquisadores e pela Sociedade Internacional de Substâncias Húmicas (STEVENSON, 1994). 


\section{2 - Estudo das estruturas das substâncias húmicas}

A estrutura das $\mathrm{SH}$ foi, durante muitos anos, objeto de investigaçōes por parte de pesquisadores Khan e Shinitzer (1980) sem no entanto, chegar a resultados satisfatórios. Entretanto, devido à sua complexidade, novas técnicas tais como fluorescência, eletroforese capilar tem sido utilizadas com o intuito de desvendar a estrutura dessas substâncias.

Existem outras teorias clássicas que levam em consideraçăo o processo de polimerização na formação das SH (FLAIG, 1964). Segundo esta teoria as SH contêm anéis aromáticos e quinonas substituídas por grupos hidroxilas, carboxilas e metoxilas. Neste sentido, (FLAIG, 1964) acreditava-se que os ácidos húmicos seriam produtos da reação exclusivamente quimica, sem envolvimento direto de microrganismos, entre açúcares redutores e aminoácidos, estes sim são originados da atividade microbiana. Os núcleos aromáticos estariam ligados por átomos de O e N (KLEINHEMPEL, 1970) enquanto que, polissacarideos e peptideos estariam presentes como estruturas lineares. Neste modelo mostrou-se o papel de cátions polivalentes, no caso dos ions $\mathrm{Fe}^{2+}$, na associação entre $\mathrm{SH}$ e a porção mineral dos solos (FISCHER, 1921; HOBSON, 1932) achavam que os ácidos húmicos eram formados a partir de ligninas modificadas. Os principais argumentos da teoria de Hobson e Page (1932) era que os ácidos húmicos teriam propriedades similares às das ligninas modificadas, com a presença de anéis aromáticos e certos grupos funcionais, por exemplo: $\mathrm{OH}$ fenólicos, e que o tratamento alcalino de ligninas leva à formação de substâncias com algumas propriedades como, solubilidade, cor, semelhantes as dos ácidos húmicos. Porém (WASKSMAN, 1938; SCHUTEN,1997) observaram que a teoria da lignina poderia não estar de acordo com a alta quantidade de nitrogênio nos $\mathrm{AH}$, então eles propuseram que a produção microbial de proteina estaria ligada quimicamente com ligninas, microbiologicamente modificadas.

Em 1931 teve uma nova proposta para uma nova estrutura quimica mais detalhada para os $\mathrm{AH}$ estes consistiam de anéis aromáticos condensados e saturados substituidos na extremidade por grupos carboxilicos e fenólicos 
(FUCHS,1931). Em 1965 (FELBECK, 1965) propôs que os AH, consistiam de unidades de pirona ligadas por pontes de metileno. Em estrutura proposta por Schnitzer e Khan (1978) os ácidos fúlvicos (AF) seriam compostos de fenóis e ácidos benzóicos unidos por ligações de hidrogênio, como apresentado na Figura 2.

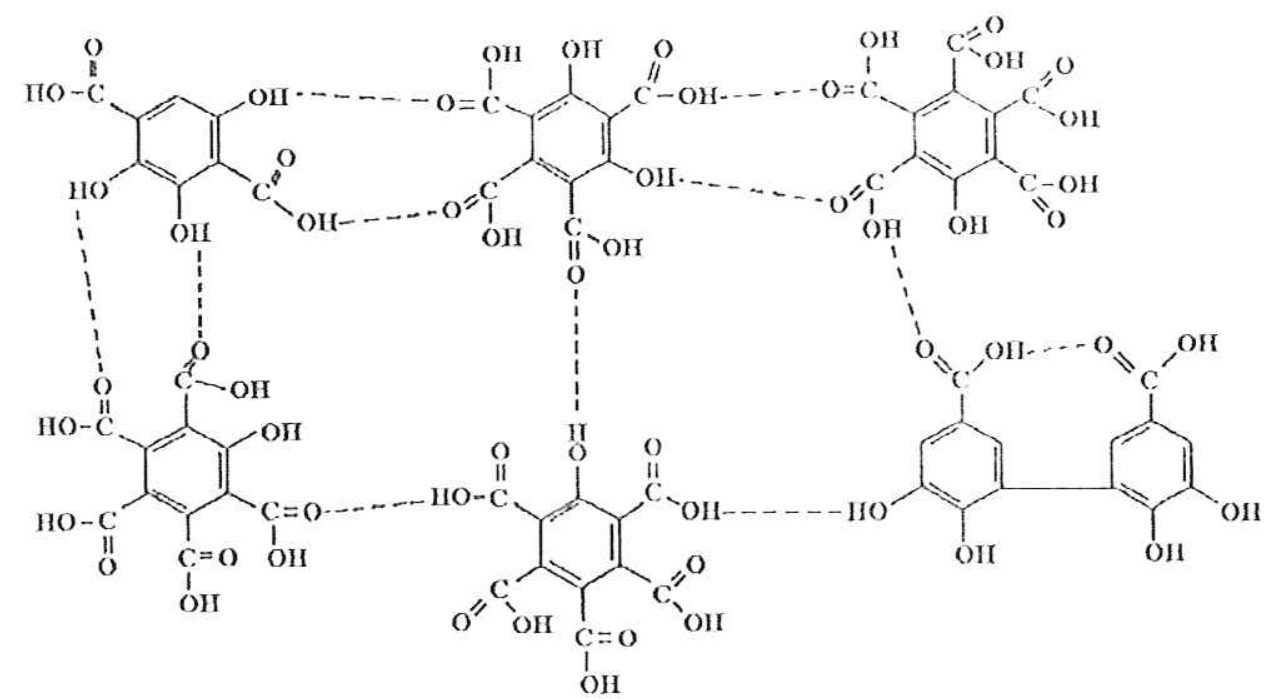

Figura 2 - Proposta de estrutura para AF por Schnitzer e Khan (1978).

Observa-se por essas propostas de estruturas para os ácidos húmicos e fúlvicos que as SH são formadas basicamente por anéis aromáticos. Utilizando dados de RMN, foi proposto um modelo para os ácidos húmicos com massa molar de $5540 \mathrm{~g} / \mathrm{mol}$ e fórmula elementar $\mathrm{C}_{308} \mathrm{H}_{328} \mathrm{O}_{90} \mathrm{~N}_{5}$ Schulten e Schinitzer (1993). Pode ser observado nesse modelo a presença de vários grupos carboxilicos, fenólicos e alcoólicos e de grupos nitrogenados como, aminas e nitrilas, além de grandes cadeias alifáticas que não são observadas nas outras propostas. Na Figura 3 encontra-se apresentada a estrutura planar para o ácido húmico proposta por Schulten et al. (1997). 


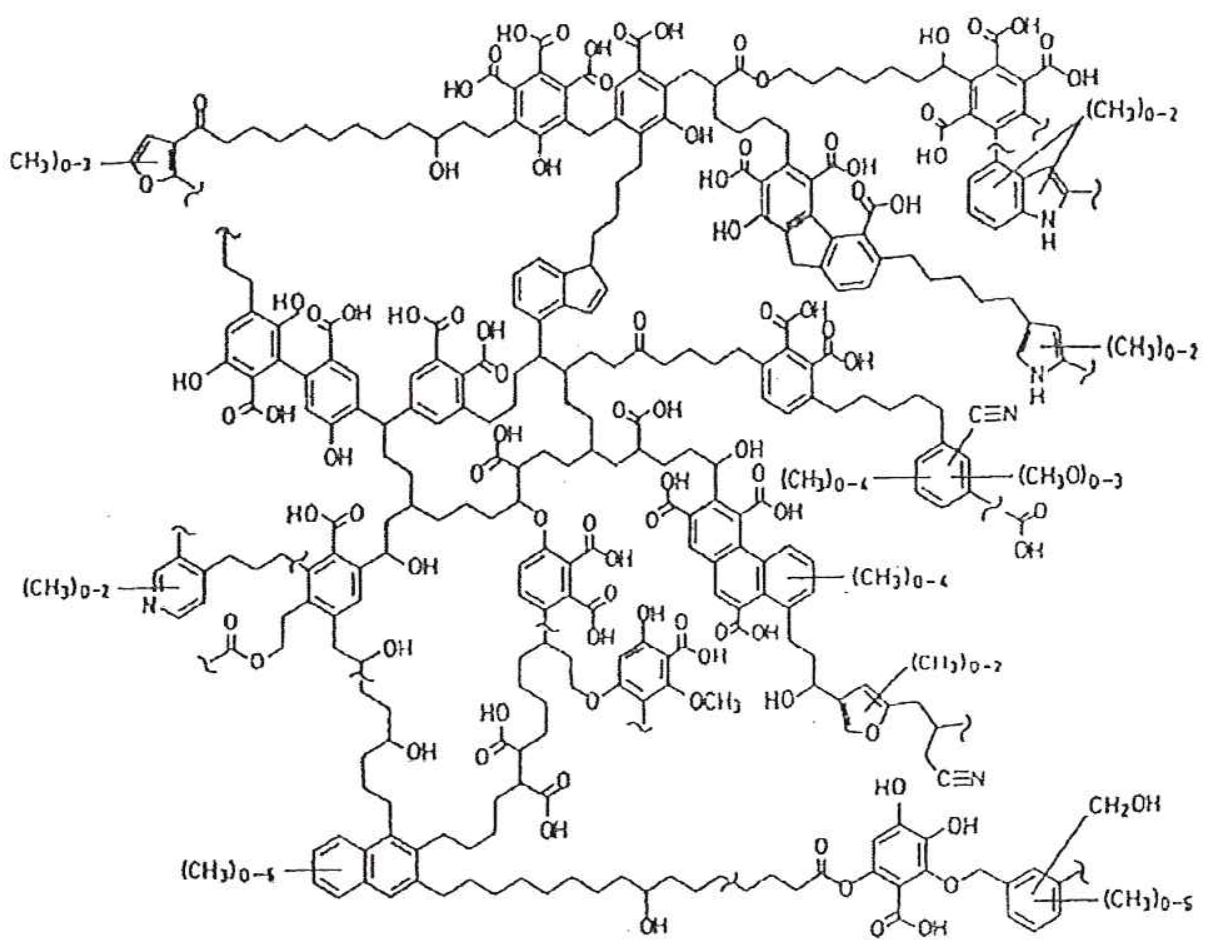

Figura 3 - Estrutura planar dos ácidos húmicos Schulten e Schnitzer (1997).

Nesta estrutura é possível observar diversos grupos funcionais tais como, carboxilicos, aminas, fenóis, álcoois e outros.

Estruturalmente, as três fraçōes húmicas (ácidos húmicos, ácidos fúlvicos e humina) são semelhantes, diferindo na massa molecular e quantidade de grupos funcionais, tendo os ácidos fúlvicos menor massa molecular, maior quantidade percentual de oxigênio e menor quantidade de carbono e nitrogênio, do que as outras frações Fukushima et al. (1996).

Sein Junior et al. (1999) apresentaram uma proposta de estrutura parcial para os ácidos húmicos, levando-se em conta o aspecto tridimensional da molécula. Os espaços intersticiais da molécula proporcionam a geometria necessária para o aprisionamento e/ou a quelação de outras substâncias. $\mathrm{Na}$ 
Figura 4 encontra-se demonstrada a estrutura tridimensional proposta para os ácidos húmicos.

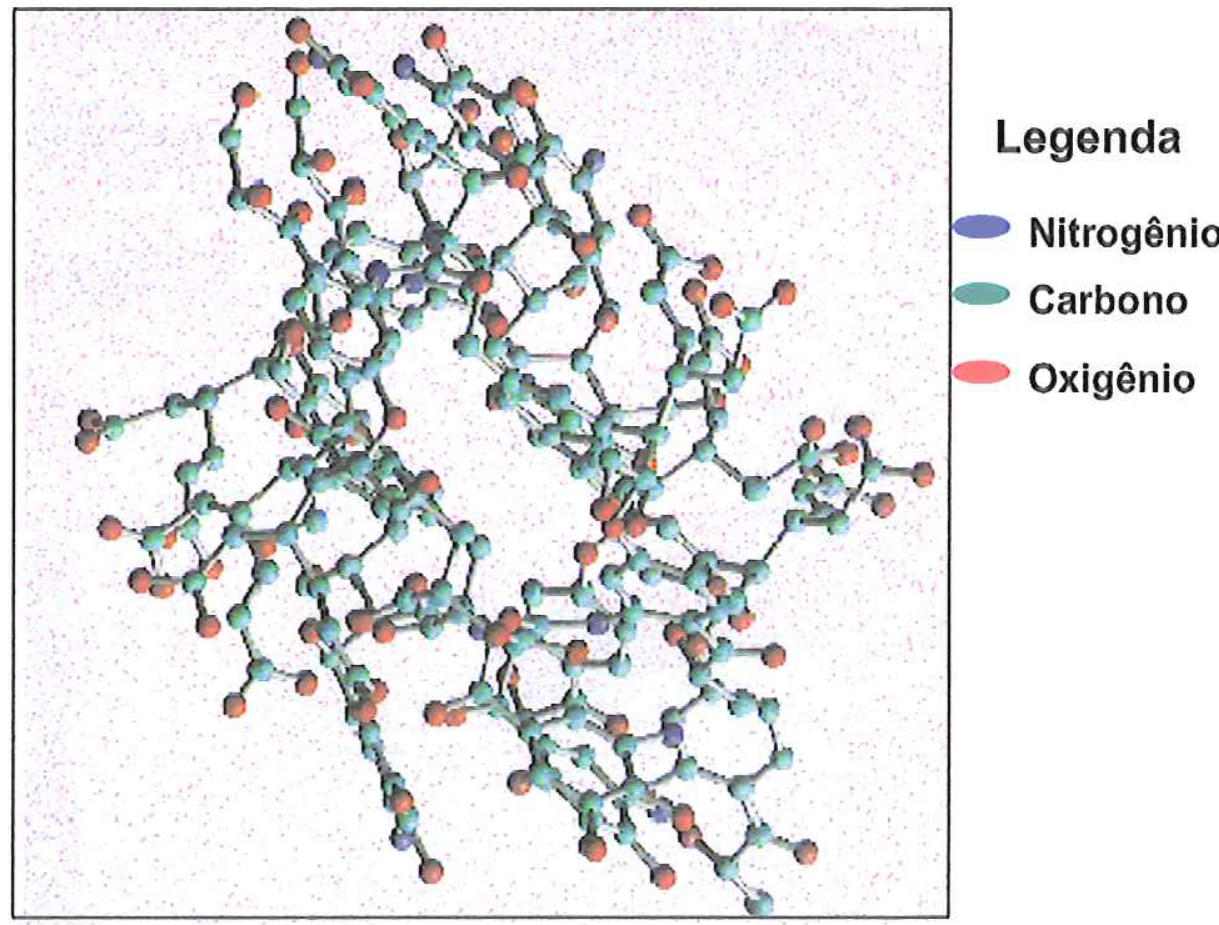

Figura 4 - Estrutura proposta para o ácido húmico Sein Junior et al.(1999).

A estrutura das $\mathrm{SH}$ são moduladas por fatores como $\mathrm{pH}$, força iônica concentração e outros. Estudos realizados por Senezer et al. (1996), empregandose microscopia eletrônica demonstraram que os $\mathrm{AH}$ exibem uma estrutura mais plana em valores de $\mathrm{pH}$ próximos de 7 e globular em $\mathrm{pH}$ menor que 3 .

Empregando estudos de ressonância magnética nuclear e degradação química de ácidos húmicos e fúlvicos (PICCOLO, 1996) foi o primeiro a propor uma descrição alternativa para a estrutura macromolecular das substâncias húmicas. Ele propôs que as $\mathrm{SH}$ em solução formariam agregados mistos de moléculas anfíílicas provenientes de produtos da degradação de plantas e complexos de lignina-carboidratos. Segundo seu trabalho, os agregados húmicos interagem por mecanismos que envolvem ligações fracas como ligações de hidrogênio e interações hidrofóbicas Piccolo et al. (1996). Considerando o conceito de micelas (TANFORD, 1991; PICCOLO, 2001), sugeriram que agregados 
húmicos seriam similares a agregados micelares, sendo seus interiores compostos de porções hidrofóbicas enquanto que componentes altamente carregados estariam posicionados nas superficies externas destes agregados. Kenworth e Hayes (1997) foram os primeiros a mostrar evidências diretas de que a estrutura macromolecular das SH poderia não ser totalmente polimérica. O grande tamanho molecular freqüentemente observado nas SH poderia ser considerado um resultado da associação de moléculas menores por forças de interações fracas, como forças de Van-der-Walls e ligações hidrofóbicas Piccolo e Conte (2000). (WERSHAW, 1986) propôs que as SH consistem de segmentos poliméricos não alterados provenientes de plantas de caráter ácido. Neste modelo as SH são agregados carregando uma parte interna hidrofóbica, e ligaçōes de transferência de cargas, com interações de hidrogênio ligado e uma parte hidrofóbica em sua superficie. Este modelo introduz o conceito de agregação de diferentes tamanhos de particulas de constituintes húmicos, em contraste com o tradicional conceito de ácidos húmicos como cadeias poliméricas lineares.

$\mathrm{Na}$ tentativa de provar que as $\mathrm{SH}$ são uma associação de pequenas moléculas (PICCOLO, 2001), realizou experimentos com o oxidante peróxido de hidrogênio $\left(\mathrm{H}_{2} \mathrm{O}_{2}\right)$ catalisado por enzimas oxidativas, peroxidase. Desta forma, se as SH são uma associação de pequenas moléculas associadas por ligações fracas em conformações não estáveis, a oxidação levaria à estruturas poliméricas estáveis. Os autores usaram a cromatografia de exclusão por lamanho com alta pressão (HPSEC) para determinar as mudanças na distribuição dos tamanhos moleculares das $\mathrm{SH}$. Os autores questionaram o conceito das $\mathrm{SH}$ serem macromoléculas, colocando em dúvida esta teoria.

Esta nova teoria proposta por (PICCOLO, 2001) pode ser interpretada de forma que as SH seriam formadas por pequenas e heterogêneas moléculas de várias origens que se auto organizam em uma conformação supramolecular. Assim pode se observar que, há muito tempo, tenta-se elucidar o tema complexo que é a estrutura das $\mathrm{SH}$, e apesar de várias pesquisas em todo mundo, ainda não se conseguiu chegar a uma teoria que fosse aceita pela maioria dos pesquisadores do assunto. 


\section{3 - Principais métodos utilizados para a extração de SH}

A primeira tentativa para isolar SH de solo foi de Achard quando submeteu solo turfoso a solventes alcalinos e obteve uma solução escura a qual precipitava por acidificação Dick e Burba (1998). Esse material solúvel em álcali e insolúvel em ácido foi denominado de ácidos húmicos. Hoje em dia ainda não existe uma metodologia para a extração de substâncias húmicas, oficialmente adotada. Alguns autores utilizam extratores mais brandos, como pirofosfato de sódio Dick e Burba (1998), agentes complexantes Whitead e Tinsley. (1967), ácido fórmico, solventes orgânicos. Porém alguns autores preferem a extração mais complexa das SH, utilizando álcalis Pinheiro e Mota (1994).

A solubilização das $\mathrm{SH}$ em meio alcalino provavelmente seja devido a conversão dos grupos ácidos, principalmente carboxilicos e fenólicos, em íons, sendo que sais como humatos de cátions polivalentes não são solúveis (STEVENSON, 1994). A Sociedade Internacional de Substâncias Húmicas apresenta um procedimento baseado em quatro horas de extração com solução de $\mathrm{NaOH}$ 0,1 mol L ${ }^{-1}$ à temperatura ambiente na razão solo/extrator 1:10 (m/v) sob atmosfera de nitrogênio Clapp et al. (1993). Rosa et al. (2000) estudaram parâmetros que influenciam no processo de extração alcalina e chegaram a seguinte conclusão: que as melhores condições para a extração das substâncias húmicas de amostras de turfa é a que utiliza solução de hidróxido de potássio $\mathrm{KOH}\left(0,5 \mathrm{~mol} \mathrm{~L}^{-1}\right)$, tempo de extração de quatro horas, razão turfa/extrator 1:20 $(\mathrm{m} / \mathrm{v})$, temperatura ambiente, atmosfera de nitrogênio e granulometria de $0,21 \mathrm{~nm}$ da turfa. Nos experimentos realizados, Rosa, verificou que o extrator $\mathrm{KOH}$ apresentou vantagens quando comparados ao $\mathrm{NaOH}$, devido ao maior rendimento e redução de co-extraidos indesejáveis.

\section{4 - Caracterização das substâncias húmicas}

A caracterização das $\mathrm{SH}$ e suas propriedades no ambiente requer a utilização de procedimentos analiticos adequados combinados com métodos quimicos, físicos e espectroscópicos. As SH são caracterizadas pelas técnicas, 
espectroscopia vibracional na região do infravermelho, espectroscopia de fluorescência, espectroscopia eletrônica na regiăo do ultravioleta e visivel, análise elementar, e ressonância magnética nuclear, dentre outras.

\subsection{1 - Espectroscopia no infravermelho com transformata de Fourier (FTIR)}

A espectroscopia vibracional na região do infravermelho (IV) permite detectar as vibrações das ligações químicas. Como estas vibrações são diretamente dependentes dos tipos de átomos a que estão ligados, é possível, através da energia de vibração de bandas, identificar os átomos ligados e assim, os grupos funcionais de uma dada molécula ou substância. Esta técnica é uma das ferramentas mais comuns para a identificação de compostos orgânicos e inorgânicos puros, pois com exceção de poucas moléculas homonucleares, tais como $\mathrm{O}_{2}, \mathrm{~N}_{2}$ e $\mathrm{Cl}_{2}$, todas as espécies moleculares absorvem radiação no IV Silverstein et al. (1994).

A intensidade de absorção é uma função da variação do momento de dipolo envolvido na vibração. São conhecidas duas categorias básicas de vibrações moleculares: uma vibração de deformação axial (estiramento) que envolve mudança continua na distância interatômica ao longo do eixo da ligação entre dois átomos e a vibração de deformação angular que é caracterizada pela mudança do ângulo entre duas ligações.

A introdução da técnica de FTIR na leitura dos espectros de infravermelho proporciona maior velocidade de leitura, permitindo a obtenção do somatório de muitos espectros, melhorando a definição dos sinais e exatidão da análise. A execução de várias varreduras para a diminuição dos residuos é facilitada devido à utilização de um computador na obtenção da transformada de Fourier.

Por intermédio dos espectros das SH pode-se obter informações na região do infravermelho com relação à natureza, à reatividade e ao arranjo estrutural dos grupos funcionais Silverstein et al. (1994). Além disso, o espectro na região de infravermelho pode indicar a presença ou a ausência de impurezas inorgânicas, como ions metálicos e argila. A espectroscopia no infravermelho com 
transformada de Fourier é útil na detecção de trocas na estrutura quimica do material húmico após oxidação, pirólise e tratamentos similares, podendo também indicar possiveis interações com pesticidas Schinitzer e Khan (1972).

As substâncias húmicas geralmente apresentam bandas de absorção

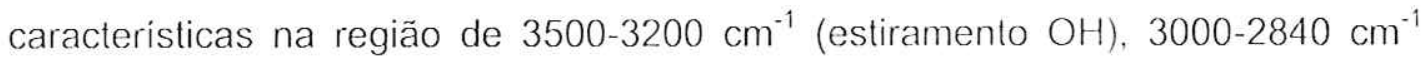
(estiramento de $\mathrm{C}-\mathrm{H}$ alifático), 1760-1680 $\mathrm{cm}^{-1}$ (estiramento de $\mathrm{C}=\mathrm{O}$ ) e 1320-1210 (estiramento de $\mathrm{C}-\mathrm{O}$ de $\mathrm{COOH}$ ).

\subsection{2 - Espectroscopia de fluorescência}

O uso da Espectroscopia de Fluorescência para o estudo de alguns aspectos moleculares e quantitativos, da estrutura e da funcionalidade das $\mathrm{SH}$, tem recebido grande atenção por parte da comunidade científica. Essa técnica tem sido aplicada principalmente no estudo de substâncias húmicas aquáticas, embora com materiais de origem terrestre também tem se mostrado promissora (SENEZI, 1990). Embora estruturas fluorescentes pareçam constituir a menor parte dos constituintes das $\mathrm{SH}$, a fluorescência intrinseca destes compostos pode fornecer informações a respeito da estrutura, conformação e heterogeneidade, assim como de aspectos dinâmicos e quantitativos relacionados às interaçōes intra e inter moleculares com outras espécies (SENEZI, 1990).

\section{4 .3 - Espectroscopia de absorção de luz no Visivel}

A razão entre as absorbâncias a 465 e $665 \mathrm{~nm}$ usualmente referida como razão $E_{4} / E_{6}$ tem sido amplamente utilizada como índice do grau de condensação dos constituintes aromáticos. No comprimento de $465 \mathrm{~nm}$ têm-se a absorbância por grupos alifáticos e no comprimento de onda de $665 \mathrm{~nm}$ por grupos aromáticos. Alguns autores têm sugerido que a razão $E_{4} / E_{6}$ fornece indicações relativas ao grau de polimerização e presença de estruturas alifáticas e aromáticas (CAMPOS, 2004), e que essa razão diminui com o aumento da massa molecular e condensação. 
Dick et al. (1998), acreditando-se que sirva como um indice do grau de humificação das SH (STEVENSON, 1982). Então uma baixa razäo pode ser um indicativo de que é alto o grau de condensação de constituintes aromáticos, enquanto que uma alta razão reflete um baixo grau de condensação aromática e indica a predominância de estruturas alifáticas.

\subsection{4 - Análise elementar}

A análise elementar é uma técnica empregada para a caracterização de substâncias húmicas. Através dessa análise se obtém informações a respeito da distribuiçăo dos elementos $(\mathrm{H}, \mathrm{N}, \mathrm{O}$ e $\mathrm{C})$ nas substâncias húmicas Stevenson et al. (1982). A relação carbono/nitrogênio tem sido utilizada para evidenciar o grau de polimerização dos ácidos húmicos (STEVENSON, 1982). Assim, o baixo teor de nitrogênio encontrado para os ácido húmicos, leva a uma alta relação carbono/nitrogênio, o que indica que o material é recente.

\section{4 .5 - Ressonância magnética nuclear (RMN)}

Esta técnica fornece importantes informações para a caracterização das SH presentes em solos e águas. As SH são normalmente caracterizadas em estado sólido e os espectros de $\operatorname{RMN}\left({ }^{13} \mathrm{C}\right)$ destas não permitem a identificação da estrutura da SH, mas é possivel estimar a concentração relativa e tipos de carbono (alifáticos e aromáticos) presentes. A estimativa das porcentagens dos diferentes tipos de carbono e prótons são obtidos a partir da integração dos picos nas regiões especificas dos espectros (SWIFT, 1996). Os principais grupos funcionais encontrados quando empregou $\mathrm{RMN}$ de ${ }^{13} \mathrm{C}$ em estado sólido em substâncias húmicas estão apresentados na Tabela 1. 
Tabela 1 - Principais picos atribuidos às substâncias húmicas.

\begin{tabular}{|l|l|}
\hline Máximo pico & \multicolumn{1}{|c|}{ Origem do sinal } \\
\hline $32-33 \mathrm{ppm}$ & $\begin{array}{l}\text { carbono associado a grupos metileno }\left(\mathrm{CH}_{2}\right)_{n} \text { em longas } \\
\text { cadeias alifáticas; carbono parafinicos. }\end{array}$ \\
\hline $57-59 \mathrm{ppm}$ & $\begin{array}{l}\text { carbonos alifáticos em grupos metoxilicos (OCH})_{3} \\
\text { nitrogenados (aninoácidos, peptideos e proteinas). }\end{array}$ \\
\hline $73-75 \mathrm{ppm}$ & $\begin{array}{l}\text { carbonos alifáticos ligados a grupos éter eH } \\
\text { (carboidratos). }\end{array}$ \\
\hline $131-133 \mathrm{ppm}$ & $\begin{array}{l}\text { carbono de anéis aromáticos ligados a grupos alquilas e } \\
\text { não a elementos eletronegaativos como O e N. }\end{array}$ \\
\hline $210 \mathrm{ppm}$ & $\begin{array}{l}\text { carbonos fenólicos ou aromáticos, podendo ter também } \\
\text { contribuição de carbono aromáticos contendo nitrogênio } \\
\text { ou grupos éteres. }\end{array}$ \\
\hline
\end{tabular}

\subsection{6 -Espectroscopia de ressonância paramagnética eletrônica nuclear (EPR)}

A descoberta da estabilidade do radical livre no solo tem sido identificada através da EPR. A espectroscopia de ressonância paramagnética nuclear é usada para identificar radicais livres semiquinona e metais de transição nas SH Martin-Neto et al. (1998). O número de radicais livres semiquinona é quantificado e é relacionado com o grau de humificação das $\mathrm{SH}$. Seu valor pode mudar quando se varia o pH da amostra em solução, quando as substâncias húmicas são submetidas ao processo de hidrólise ácida, quando se altera a temperatura, quando há processo redox, quando as substâncias húmicas são irradiadas por luz UV (SENESI, 1990, 1992). As semiquinonas podem ser produzidas pela redução de quinonas ou por oxidação de fenóis, como apresentas na Figura 5. Sob condições alcalinas ânions semiquinonas são formados. 


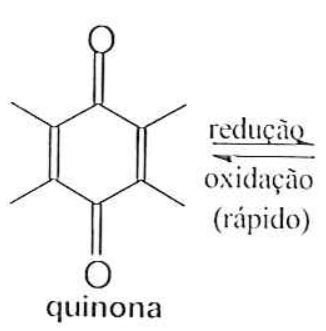<smiles>Cc1c(C)c(O)c(C)c(C)c1[O-]</smiles>

semiquinona<smiles>C=C=[C+]Oc1c(C)c(C)c([O])c(C)c1C</smiles>

ânions semiquinona
Hidroquinona<smiles>Cc1c(C)c(O)c(C)c(C)c1O</smiles><smiles>Cc1c(C)c(O)c(C)c(O)c1C</smiles>

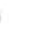




\section{5 - OBJETIVOS}

Fracionar as substâncias húmicas coletadas às margens do Rio Mogi-Guaçu no Km 40 da rodovia SP-255, no municipio de Luis Antônio em diferentes tamanhos moleculares, e também determinar sistematicamente as propriedades estruturais e funcionais das frações pela combinação de técnicas espectroscópicas incluindo infravermelho com transformada de Fourier (FTIR), ressonância magnética nuclear (RMN), absorção de luz no Visivel (razão $E_{4} / E_{6}$ ), ressonância paramagnética eletrônica (EPR) e também por análise elementar e acidez carboxílica, fenólica e total.

\section{6 - PARTE EXPERIMENTAL}

\subsection{1.- Coleta e preparo das amostras}

As amostras de turfa utilizadas neste trabalho foram coletadas em uma turfeira às margens do Rio Mogi Guaçu, no Km 40 da rodovia SP-255, no municipio de Luis Antônio. Foram coletadas a uma profundidade de $45 \mathrm{~cm}$, por intermédio de um amostrador Hiller, armazenadas em sacos de polietileno e. conduzidas ao laboratório onde foram secas ao ar livre, trituradas em um equipamento tipo mandibula e peneirada em malha $2 \mathrm{~mm}$ para posterior extração das substâncias húmicas.

\subsection{2 - Extração das substâncias húmicas}

Para extração das SH foi utilizado o método sugerido por Rosa et al. (2000). Este método foi utilizado, pois a soluçăo $\mathrm{KOH}$ tem mostrado maior rendimento na extração das $\mathrm{SH}$, apesar da solução de $\mathrm{NaOH}$ ser recomendada pela Sociedade Internacional de Substâncias Húmicas na extração das SH. Um maior rendimento é importantíssimo para o trabalho devido ao fato de 
a extração ter sido realizada em batelada com procedimento simples, sem qualquer método mais específico de purificação, colunas de troca iônica, e sem o fracionamento das $\mathrm{SH}$ em ácidos húmicos e fúlvicos, procedimentos geralmente utilizados quando se trabalha com SH.

Rosa et al. (2000) verificou os melhores parâmetros para a extração alcalina das SH de turfa. Os parâmetros utilizados foram:

“ extração em solução $0,5 \mathrm{~mol} \mathrm{~L}^{-1}$ de hidróxido de potássio $(\mathrm{KOH})$;

* tempo de agitação de 4 horas;

- razão turfa/extrator 1:20 (m/v);

" temperatura ambiente;

" decantação por 48 horas.

A decantação, foi realizada com a finalidade de separar-se a humina insolúvel em $\mathrm{pH}$ básico das $\mathrm{SH}$ (ácido fúlvico e húmico), solúvel neste $\mathrm{pH}$. A seguir foi coletado o sobrenadante e adicionado em saquinhos feito com papel celofani. Essas embalagens foram colocadas em solução de $\mathrm{HCl} 1 \%$, para redução do $\mathrm{pH}$. As embalagens permaneceram nesse banho por 3 dias, trocando a solução 3 vezes ao dia. As amostras passaram pelo processo de diálise para a retirada do excesso de sais. Para a eliminação dos íns cloretos os saquinhos feitos com papel celofani foram colocados em uma caixa de água e cobertos com água não clorada. O fluxo de entrada e saida da água foram controlados. Este processo foi realizado por 15 dias, até teste negativo de ions cloretos, empregando para tanto nitrato de prata $\left(\mathrm{AgNO}_{3}\right)$. Após esta etapa as $\mathrm{SH}$ foram retiradas dos saquinhos, guardadas em garrafas de plástico é armazenadas no freezer para posterior fracionamento. Na Figura 6 está apresentado o fluxograma que ilustra todo o procedimento de extração e purificação das SH, já discutidos. 


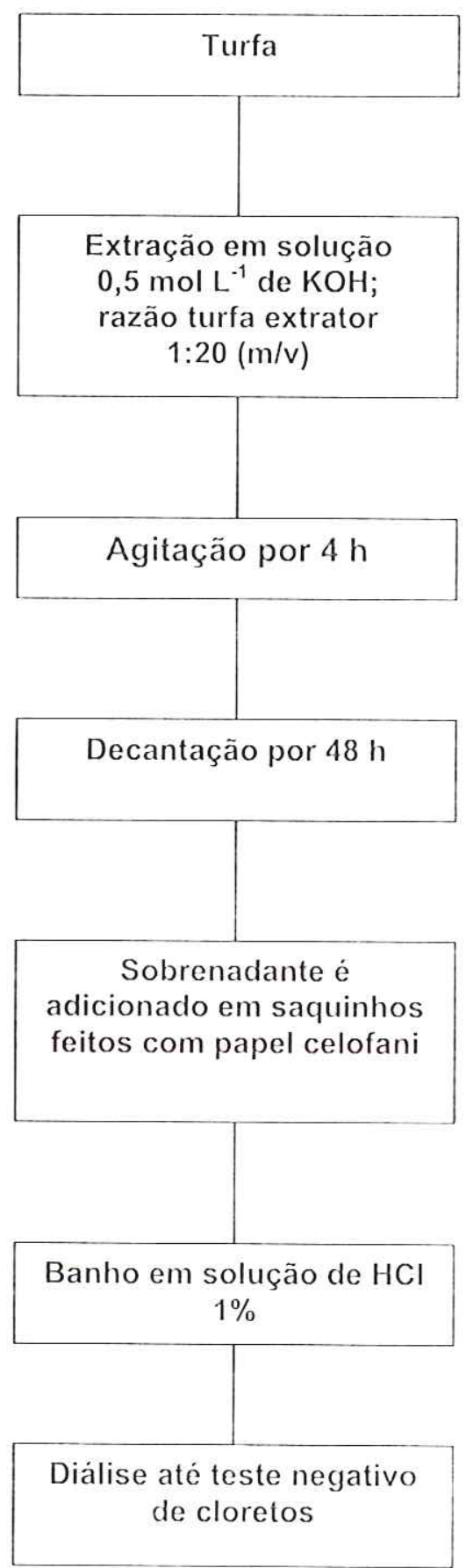

Figura 6 - Fluxograma das etapas envolvidas na extração das SH. 


\subsection{3 - Fracionamento das $\mathrm{SH}$ em diferentes tamanhos moleculares}

As $\mathrm{SH}$ foram fracionadas utilizando-se um equipamento sequencial de ultrafracionamento (vivaflow 50), fabricado pela Vivascience, equipado com membranas de polyethersulfone, bomba peristáltica e reservatório da amostra. As membranas foram dispostas duas a duas, com mesmo tamanho de poro e em paralelo como apresentado na Figura 7, com fluxo tangencial do filtrado.

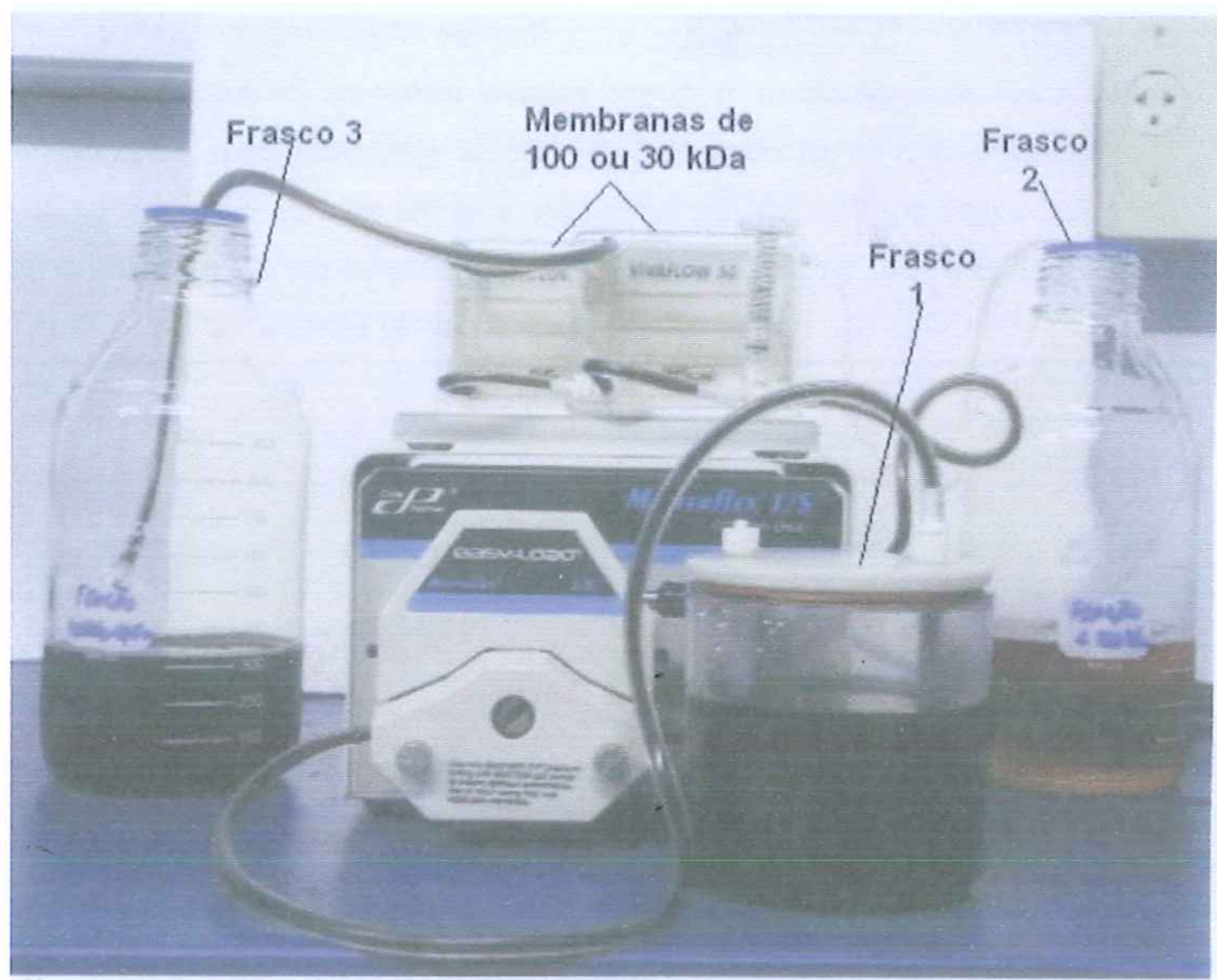

Figura 7- Foto do equipamento sequencial de ultrafracionamento ( vivaflow 50) (CAMPOS, 2004).

Antes de se iniciar o processo de ultrafracionamento das $\mathrm{SH}$, essas foram filtradas inicialmente em papel de filtro de porosidade $0,45 \mu \mathrm{m}$ da marca Schleicher \& Scuell. Após esta etapa a amostra foi fracionada utilizando-se o equipamento apresentado na Figura 7. As $\mathrm{SH}$ foram fracionadas em dois tamanhos moleculares > $100 \mathrm{KDa}$ e 30-100 KDa sendo que uma amostra foi 
apenas filtrada em 0,45 $\mu \mathrm{m}$. Para filtração desta amostra sem fracionamento foi utilizado um suporte de teflon, um kitassato e uma bomba de vácuo. O pH de filtração foi mantido em $(\sim 7,0)$, já que este, satisfaz as exigéncias para este tipo de membrana. Depois de utilizadas, as membranas foram limpas com solução de $\mathrm{NaOH} 0,1 \mathrm{~mol} \mathrm{~L}^{-1}$ e água deionizada. Após a limpeza as membranas foram guardadas em etanol a $1 \%$.

\subsection{4 - Liofilização das frações}

Depois de fracionadas as frações foram concentradas em um rotaevaporador a uma temperatura de $30^{\circ} \mathrm{C}$ à pressão reduzida. Em seguida as fraçōes foram liofilizadas para posterior caracterização. A Liofilização foi realizada em um equipamento da marca Edwards, modelo F101-02-000.

\subsection{5 - Caracterização das frações das SH}

\subsubsection{1 - Espectroscopia de infravermelho com transformata de Fourier (FTIR)}

A espectroscopia no infravermelho tem sido utilizada para identificar grupos funcionais presentes nas SH. Informações sobre grupos funcionais como ácidos carboxilicos, aminas, hidróxidos, grupos alifáticos dentre outros pode ser obtidas Davis et al. (1999). Os espectros foram obtidos a partir das pastilhas de $\mathrm{KBr}$, sendo que 1,0 mg da amostra das substâncias húmicas e 10,0 mg de brometo de potássio $(\mathrm{KBr})$, foram colocados em um almofariz de ágata, para o preparo da pastilha a ser analisada. As análises foram realizadas em espectrômetro com transformada de Fourier, da marca Bomem MB- 102 Barros el al. (1994). Foram realizadas 16 varreduras com resolução espectral de $4 \mathrm{~cm}^{-1}$. 


\subsubsection{2 - Espectroscopia na região do visível razão $E_{4} / E_{6}$}

Pesou-se 2,0 mg das substâncias húmicas, a qual foi dissolvida em $100 \mathrm{~mL}$ de solução de bicarbonato de sódio $0,005 \mathrm{~mol} \mathrm{~L}^{-1}$. Foi obtido um espectro na região do visivel dessas soluções, anotando-se as absorbâncias obtidas nos comprimentos de onda de $465 \mathrm{~nm}$ e $665 \mathrm{~nm}$. Utilizou-se um espectrofotômetro de UVIVisivel Hitachi modelo U3501. A razão $E_{4} / E_{6}$ é a razäo entre as duas absorbâncias medidas nos comprimentos de onda de 465 e 665 nm. Estas medidas são indicativos do grau de condensação aromática da estrutura. No comprimento de $465 \mathrm{~nm}$ têm-se a absorbância por grupos alifáticos e no comprimento de onda de $665 \mathrm{~nm}$ por grupos aromáticos.

\subsubsection{3 - Análise elementar}

As análises elementares foram realizadas pela Central de Análises Quimicas e Instrumentais do Instituto de Quimica de São Carlos, utilizando-se o aparelho CE Instruments EA 1110 CHNS - O da marca Fisons, com detector de condutividade térmica. Quantificou-se carbono, hidrogênio, nitrogênio e enxofre (em porcentagem em massa). O teor de oxigênio foi obtido pela diferença [100 $(\% \mathrm{C}+\% \mathrm{H}+\% \mathrm{~N}+\% \mathrm{~S})]($ FALONE, 2002).

\subsubsection{4 - Análises de Ressonância Paramagnética eletrônica (EPR)}

As análises feitas por EPR para quantificar os radicais livres semiquinonas foram realizadas na Empresa Brasileira de Pesquisas Agropecuárias (EMBRAPA), em São Carlos, usando o espectrômetro de EPR da Bruker - EMX cavidade retangular, banda $X(\approx 9,0 \mathrm{GHz})$ em temperatura ambiente. Para a quantificação dos radicais livres tipo semiquinona, foi utilizado o método do padrão secundário (SINGER, 1959), com um cristal de rubi $\left(\mathrm{Al}_{2} \mathrm{O}_{3}\right)$ contendo $0,5 \%$ de $\mathrm{Cr}^{+3}$ por peso. Seu fator $g$ é de 1,263 e, portanto, não interfere com o sinal do radical livre semiquinona, cujo valor de $g$ está em torno de 2,003 (MARTIN-NETO, 1998). 
Foram colocados cerca de $20 \mathrm{mg}$ de cada fração das SH em tubos de quartzo. As quantidades de radicais livres foram determinadas normalizando-as pela massa. A potência de microondas (P) utilizada foi de $0,08 \mathrm{~mW}$ e a amplitude de modulação de $2 \mathrm{G}_{\mathrm{pp}}$ (Gauss pico a pico). Foram utilizadas 9 varreduras para as medidas de radicais livres. Foi feita uma curva de saturação para obter-se as condições ótimas de análise dos radicais livres. Para isto foram realizadas 6 medidas em potência baixa com passo de $2 \mathrm{~dB}$ variando a potência de $3,173 \mathrm{nW}$ a $50,29 \mu \mathrm{W}, 3$ medidas em potência média com passo de $2 \mathrm{~dB}$ variando a potência de $79,7 \mu \mathrm{W}$ a $0,797 \mathrm{~mW}$ e 1 medida em potência alta com passo de $6 \mathrm{~dB}$ variando a potência de $3,181 \mathrm{~mW}$ a $50,41 \mathrm{~mW}$. Foi feita uma varredura de 5000 Gauss para verificar a presença de ions paramagnéticos nas amostras, utilizando uma potência de $1 \mathrm{~mW}$ e amplitude de modulação de $10 \mathrm{G}_{\mathrm{pp}}$. Calculou-se o fator $\mathrm{g}$ para verificar se o radical encontrado nas frações é do tipo semiquinona. Para este cálculo foi utilizado o padrão de DPPH ( $\alpha$ c. difenil $\beta$ picril hidrozil) com valor conhecido de g $(2,0036)$ e o software Winer Sinfonia para simulação de espectros.

\subsubsection{5- Análises de ressonância magnética nuclear de $\mathrm{C}^{13}$ em estado sólido (RMN de $\mathrm{C}^{13}$ )}

As análises de RMN de $\mathrm{C}^{13}$ foram realizadas no Instituto de Fisica de São Carlos-USP. As medidas foram realizadas em um espectrômetro VARIAN Unit INOVA usando a técnica de polarização cruzada, rotação da amostra em torno do ângulo mágico e desacoplamento em alta potência (CP/MAS). Utilizou-se uma freqüência de $100,5 \mathrm{MHz}$ e uma velocidade de rotação da mostra em torno do ângulo mágico de $6 \mathrm{kHz}$. A duração do pulso foi de 4 us com tempo de repetição de 2 s e tempo de contato para transferência da polarizaçăo de $1 \mathrm{~ms}$. A janela espectral foi de $70 \mathrm{kHz}$ com tempo de aquisição de $30 \mathrm{~ms}$. 


\subsubsection{6 - Determinação da acidez carboxílica, fenólica e total}

\subsubsection{1 - Acidez carboxílica}

Colocou-se $50 \mathrm{mg}$ das amostras das frações das SH de diferentes tamanhos moleculares em erlenmeyers de $25 \mathrm{~mL}$, juntamente com $20 \mathrm{~mL}$ de solução $0,1 \mathrm{~mol} \mathrm{~L}^{-1}$ de acetato de cálcio $\left(\mathrm{Ca}\left(\mathrm{CH}_{3} \mathrm{COO}\right)_{2}\right.$. A água utilizada para preparar as soluções foi previamente fervida para retirada de $\mathrm{CO}_{2}$. Foi também preparado um branco de $20 \mathrm{~mL}$ de solução de acetato de cálcio. Passou-se um fluxo de nitrogênio nos erlenmeyers, que foram então submetidos à agitação por $24 \mathrm{~h}$ à temperatura ambiente. Em seguida, as suspensões foram filtradas em papel de filtro comum, sendo coletados $10 \mathrm{~mL}$ do filtrado, os quais foram titulados pontenciometricamente com uma solução de $\mathrm{NaOH} 0,05 \mathrm{~mol} \mathrm{~L}^{-1}$. O ponto de equivalência foi determinado em $\mathrm{pH}$ 9,8. A acidez foi calculada pela eq.(1).

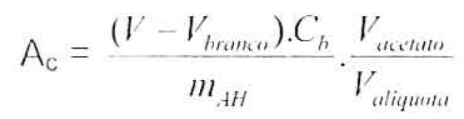

Onde:

$A_{c}=$ acidez total $(\mathrm{em} \mathrm{mmolc/g}) ;$

$\mathrm{V}=$ volume de $\mathrm{NaOH}$ usado na titulação

$\mathrm{V}_{\text {branco }}=$ volume de $\mathrm{NaOH}$ usado na titulação do branco;

$\mathrm{C}_{\mathrm{b}}=$ concentração de $\mathrm{NaOH}$;

$\mathrm{M}_{\mathrm{AH}}=$ massa da substância húmica;

$\mathrm{V}_{\text {acetato }}=$ volume total de acetato de cálcio utilizado $(20 \mathrm{~mL})$;

$V_{\text {aliquota }}=$ volume da aliquota utilizado na titulação $(10 \mathrm{~mL})$; 


\subsubsection{2 - Acidez total}

Colocou-se $100 \mathrm{mg}$ das amostras das frações de substâncias de diferentes tamanhos moleculares em erlenmeyers de $25 \mathrm{~mL}$, juntamente com $10 \mathrm{~mL}$ de solução $0,1 \mathrm{~mol} \mathrm{~L}^{-1}$ de $\mathrm{Ba}(\mathrm{OH})_{2}$. A água utilizada para preparar a solução alcalina foi previamente fervida para retirada de $\mathrm{CO}_{2}$. Foi preparado também um branco, constituido de apenas $10 \mathrm{~mL}$ da solução de $\mathrm{Ba}(\mathrm{OH})_{2}$. Passou-se um fluxo de nitrogênio nos erlenmeyers, que foram então submetidos à agitação por 24 h á temperatura ambiente. Em seguida as suspensões foram filtradas em papel de filtro comum, sendo coletados $10 \mathrm{~mL}$ do filtrado, os quais foram titulados potenciometricamente com uma solução padrão de $\mathrm{HCl} 0,05 \mathrm{~mol}^{-1} \mathrm{~L}^{-1}$. O ponto de equivalência foi determinado em $\mathrm{pH} 8,4$. A acidez total foi calculada pela eq.(2).

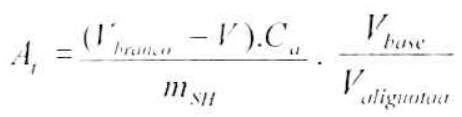

onde:

$$
\begin{aligned}
& A_{T_{t}}=\text { acidez total (em mmolc/g) } \\
& V_{\text {branco }}=\text { volume de } \mathrm{HCl} \text { usado na titulação do branco; } \\
& \mathrm{V}=\text { volume de } \mathrm{HCl} \text { usado na titulação da amostra; } \\
& \mathrm{C}_{\mathrm{a}}=\text { concentração da solução de } \mathrm{HCl} ; \\
& \mathrm{m}_{\mathrm{SH}}=\text { massa da substância húmica; } \\
& V_{\text {base }}=\text { volume total de } \mathrm{Ba}(\mathrm{OH})_{2} \text { utilizado }(10 \mathrm{~mL}) ; \\
& V_{\text {aliquota }}=\text { Volume da aliquota utilizado na titulação }(5 \mathrm{~mL}) ;
\end{aligned}
$$

\subsubsection{3 - Acidez fenólica}

A determinação da acidez fenólica foi feita por diferença entre acidez total e carboxilica. 


\section{7 - Resultados e Discussão}

1.7.1 - Análise espectroscópica por inf́ravermelho com transformada de Fourier

A espectroscopia no infravermelho tem sido utilizada para caracterizar as substâncias húmicas fornecendo informações estruturais e funcionais das moléculas que as compõem. Na Figura 8 estão apresentados os espectros de IV para todas as frações das $\mathrm{SH}$.

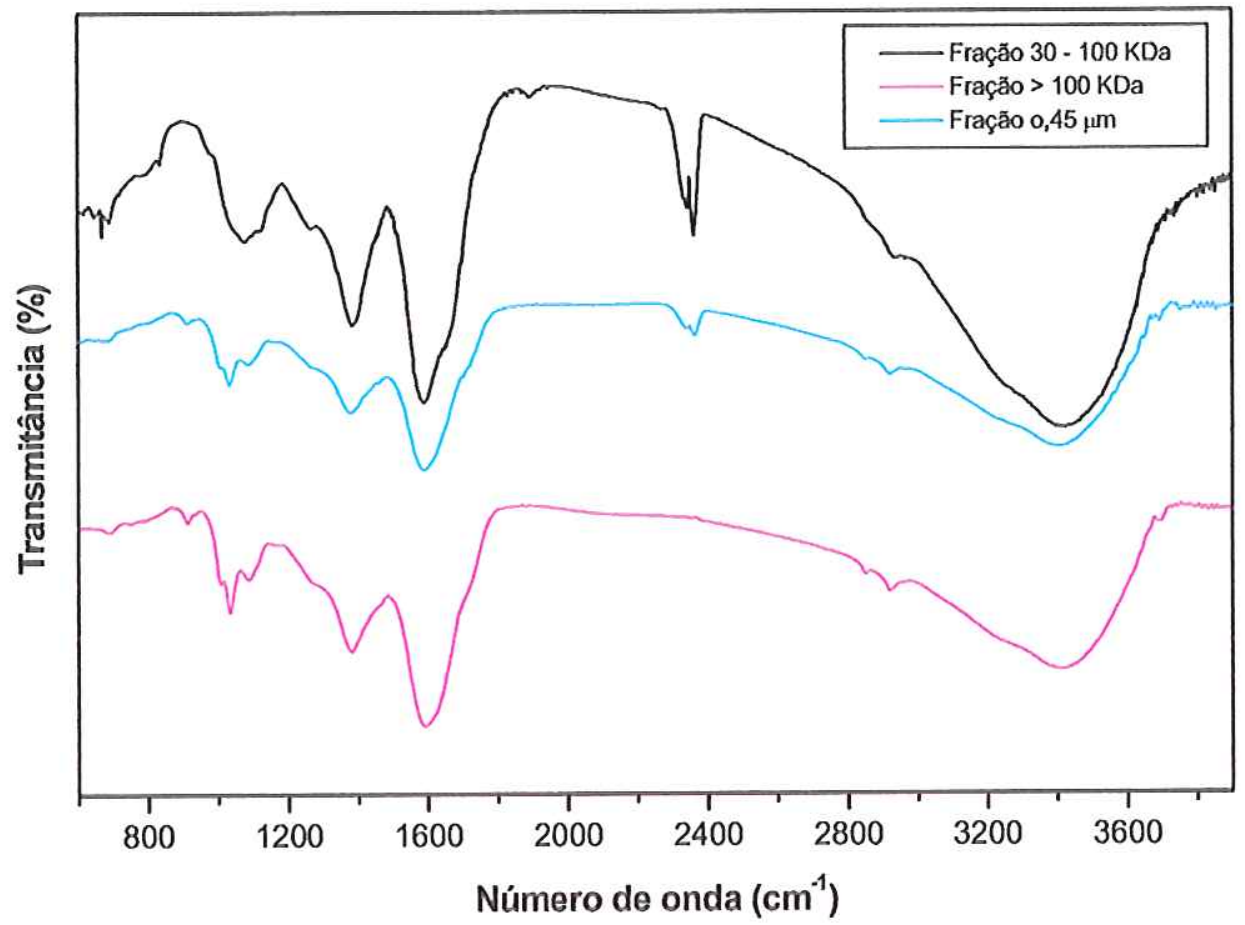

Figura 8- Espectros de IV para as frações das SH.

Para melhor compreensão dos espectros de infravermelho apresentados na Figura 8, a seguir encontra-se a Tabela 2 na qual estão discriminadas as principais bandas das substâncias húmicas com suas possíveis atribuicões. 
Tabela 2 - Principais bandas observadas na região do infravermelho nas substâncias húmicas e suas possivèis atribuições Ricca et al. (2000).

\begin{tabular}{|c|c|}
\hline Bandas & Atribuições \\
\hline $3500-3300$ & Estiramento de $\mathrm{OH}$ carboxílico, fenol, álccol ou água \\
\hline 2900 e 2850 & Estiramento de $\mathrm{C}-\mathrm{H}$ alifático \\
\hline$\sim 1720$ & $\mathrm{C}=\mathrm{O}$ de ácidos carboxilicos, aldeidos e cetonas \\
\hline$\sim 1640$ & 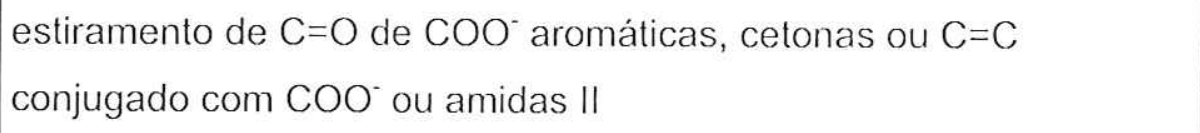 \\
\hline$\sim 1583$ & estiramento de $\mathrm{C}=\mathrm{C}$ de aromáticos e amidas $\mathrm{NH}_{2}$ ou $\mathrm{NH}$ \\
\hline$\sim 1450$ & $\begin{array}{l}\text { Deformação de C-H alifático de grupos } \mathrm{CH}_{2} \text { ou } \mathrm{CH}_{3} \text {, ou composto de } \\
\mathrm{N} \text { elou S }\end{array}$ \\
\hline 1408 & deformação de C-H alifáticos; estiramento assimétrico de $\mathrm{COO}^{-}$ \\
\hline $1150-1050$ & presença de Si-O \\
\hline $1100-1040$ & Estiramento C-O de polissacarideos \\
\hline $890-820$ & Composto de Si-O, Si-H e P-O \\
\hline$\sim 770$ & Estiramento de cadéias alifáticas \\
\hline
\end{tabular}

Analisando-se os espectros apresentados na Figura 8 e comparando com a Tabela 2, verifica-se alguns picos característicos das SH. Observa-se que todas as fraçōes apresentaram uma banda larga e intensa, muito peculiar centrada em torno de $3419 \mathrm{~cm}^{-1}$, que é atribuida a uma superposição de bandas, que estão relacionadas com estiramento de $\mathrm{O}-\mathrm{H}$ de grupamentos carboxillicos, fenólicos, alcóois e da água ligada Prado e Rezende (1999). Já na região de 3000 a 2900 $\mathrm{cm}^{-1}$ observa-se o aparecimento de duas bandas, que são atribuidas respectivamente aos estiramentos anti-simétrico e simétrico de $\mathrm{C}-\mathrm{H}$ dos grupos alifáticos (BARROS, 1993; PRADO, 1999). A banda intensa na região de $1600 \mathrm{~cm}$ ${ }^{1}$ pode ser atribuida ao estiramento $\mathrm{v}(\mathrm{C}=\mathrm{C})$ do anel, e as vibrações do esqueleto aromático. Esta banda também pode ser atribuida ao estiramento anti-simétrico do grupo carboxilato vás $\left(\mathrm{COO}^{-}\right)$e ao estiramento v $(\mathrm{C}=\mathrm{O})$ do grupo $\mathrm{COOH}$, devido ao $\mathrm{H}$ ligado ao grupo $\mathrm{OH}$ em posição orto, como no ácido salicílico (BARROS, 1999; SILVERSTEIN, 1994). Em todas as frações das SH verificou-se 
uma banda na região $1380 \mathrm{~cm}^{-1}$ que pode ser atribuida tanto a deformação $\delta(\mathrm{OH})$, quanto ao estiramento $v(\mathrm{C}-\mathrm{O})$ de grupos fenólicos e também ao estiramento antisimétrico de COO. Na região de $1250 \mathrm{~cm}^{-1}$, tem-se uma banda que pode ser atribuida ao v(C-O) de alcóois, fenóis e grupos carboxilicos Francisco et al. (2002).

As bandas na região de 1000 a $1100 \mathrm{~cm}^{-1}$ são referentes a estiramentos de C-O de carboidratos e alcóois e ainda às vibrações de ligações C-C de alifático ou $\mathrm{CH}$ de anéis aromáticos. Esses resultados estão de acordo com a literatura Francisco et al. (2002).

\subsection{2 - Análise espectroscópica na região do visível (razão $E_{4} / E_{6}$ )}

A relação $E_{4} / E_{6}$ corresponde a razão entre as absorbâncias em 465 e 665 $\mathrm{nm}$, que é freqüentemente utilizada por muitos cientistas para as caracterizações das substâncias húmicas Chen et al. (1977). Esta razão está diretamente relacionada à condensação estrutural, sendo indicativo do grau de humificação, aromaticidade, massa molecular e conteúdo ácido das SH (SWIFT, 1996).

Um baixo valor da razão $E_{4} / E_{6}$, indica alto grau de condensação dos constituintes aromáticos, enquanto que um alto valor de $E_{4} / E_{6}$ reflete em menor condensação e é resultante da presença de estruturas predominantemente alifáticas (FALONE, 2002). A razão $E_{4} / E_{6}$ é influenciada pelo tamanho da molécula, $\mathrm{pH}$ do meio, pelo conteúdo de oxigênio, carbono, grupos carboxilicos, origem e idade (STEVENSON, 1982).

$\mathrm{Na}$ Tabela 3 encontram-se apresentados os valores das razões $E_{4} / E_{6}$ para todas as frações das SH. 
Tabela 3 - Valores das absorbâncias em 465 e $665 \mathrm{~nm}$ e valores da razão $E_{4} / E_{6}$.

\begin{tabular}{|c|c|c|c|}
\hline & \multicolumn{2}{|c|}{ Absorbâncias } & \\
\hline Frações & $465 \mathrm{~nm}$ & $665 \mathrm{~nm}$ & Razão $\mathrm{E}_{4} / \mathrm{E}_{6}$ \\
\hline $0,45 \mu \mathrm{m}$ & 0,156 & 0,046 & 3,39 \\
\hline$>100 \mathrm{KDa}$ & 0,179 & 0,058 & 3,09 \\
\hline $30-100 \mathrm{KDa}$ & 0,190 & 0,025 & 7,60 \\
\hline
\end{tabular}

Analisando-se os resultados apresentados na Tabela 3 , verifica-se que as substâncias húmicas filtrada em papel de filtro $0,45 \mu \mathrm{m}$, apresenta um valor para razão $E_{4} / E_{6}$ de 3,39 o que indica que esta fração $0,45 \mu$ m de substâncias húmicas extraida da turfa, apresenta um maior número de estruturas aromáticas em comparação às estruturas alifáticas, em decorrência de um alto grau de humificação, condizente com a matriz, que decorre de uma era geologicamente antiga (SUSZCZYNSI, 1982). Já a fração das SH de tamanho molecular molecular entre 30 - $100 \mathrm{KDa}$, apresenta um alto valor da razão $E_{4} / E_{6}$ que é de 7,6 , o que indica que esta fração apresenta uma menor quantidade de anéis condensados do que nas outras fraçōes. $O$ alto valor de $E_{4} / E_{6}$, indica a predominância de estruturas alifáticas em relação às aromáticas Senesi e Schnitzer (1977). O valor da razão $E_{4} / E_{6}$ para a fração maior que $100 \mathrm{KDa}$ é menor do que o valor encontrado para a fração filtrada em filtro de porosidade $0,45 \mu \mathrm{m}$, devido esta fração ter um maior valor de absorbância a $665 \mathrm{~nm}$ em relação a substância húmica filtrada em 0,45 بm.

Estes resultados estão de acordo com os encontrados por outros autores que estudaram as $\mathrm{SH}$ de diferentes localidades e concluiram que a razão $E_{4} / E_{6}$ decresce com o aumento da massa molecular e do grau de condensação Summers et al. (1987). 


\subsection{3 - Ressonância magnética nuclear de $\mathrm{C}^{13} \mathrm{em}$ estado sólido} (RMN de $\mathrm{C}^{13}$ )

A espectroscopia de ressonância magnética nuclear (RMN) fornece importantes informações para a caracterização das $\mathrm{SH}$ presentes em solos e águas Rocha e Rosa (2003).

Os espectros de $\mathrm{RMN}\left({ }^{13} \mathrm{C}\right)$ de $\mathrm{SH}$ não permitem a identificação da estrutura das $\mathrm{SH}$, mais é possível estimar a concentração relativa e tipos de carbonos, alifáticos e aromáticos, presentes (SWIFT, 1996).

$\mathrm{Na}$ Figura 9 encontram-se apresentados os espectros de RMN CP/MAS de ${ }^{13} \mathrm{C}$ para as frações das $\mathrm{SH}$ estudadas.

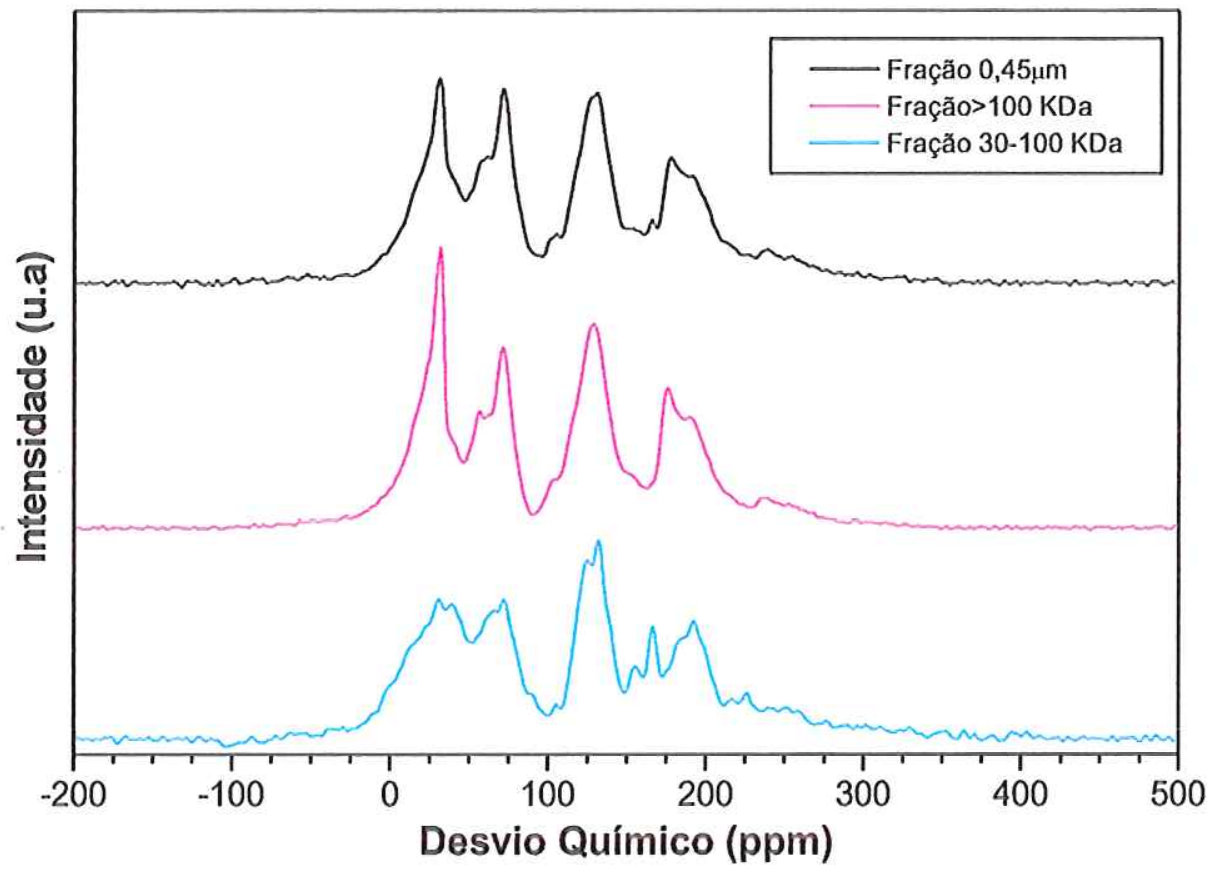

Figura 9 - Espectros de RMN CP/MAS de ${ }^{13} \mathrm{C}$ para as frações das $\mathrm{SH}$.

Os espectros das $\mathrm{SH}$, geralmente podem ser divididos em quatro regiões químicas Lu et. al. (2000). A região de 0-50 ppm representa a ressonância de carbonos alifáticos, metil, metileno, a região de 50-110 ppm, carbonos alifáticos oxigenados, a região 100-160 ppm carbonos aromáticos e a região entre 160-220 ppm, a carbonos carboxílicos, CO carboxílicos e CO de cetonas. 
Analisando-se os espectros apresentados na Figura 9, verificou-se que estes apresentam os mesmos picos, porém não se pode comparar a intensidade dos picos devido a utilização de massas diferentes.

$\mathrm{Na}$ região dos alifáticos, observou-se um pico intenso em torno de 32 ppm, que representa a ressonância de carbonos alifáticos (metil, metileno) Francioso et al. (2001). Já na região de carbonos alifáticos oxigenados verificou-se um pico de ressonância entre 50-65 ppm que consiste na ressonância de grupos metóxilicos, $-\mathrm{OCH}_{3}$, (CARVALHO, 2003). O pico que está em torno de 71-73 ppm, é atribuido às cadeias de polissacarídeos, tais como, celulose (MALCOM, 1989). O pico observado na região entre 100-110 ppm é atribuido a carbonos anômericos de carboidratos, C-2, C-6 de unidades de sirigila e lignina estando de acordo com os resultados obtidos por Francioso et al. (2001).

A região de 110-140 ppm é atribuída à ressonância de carbonos aromáticos de alquil substituidos e não substituidos, pois aromáticos protonados ressonam no intervalo de 110-120 ppm, e os carbonos aromáticos de alquil substituídos e não substituidos na faixa de 120-140 ppm (FRIMMEL, 1998, 2000).

$\mathrm{Na}$ fração entre 30-100 KDa verificou-se sinais intensos em 122 e 132 ppm, que segundo Francioso et al. (2003), são atribuidos a carbonos aromáticos alquil substituidos ou com nitrogênio ou oxigênio grupos doadores de elétrons. Nas demais frações observou-se apenas o pico na região de 132 ppm e não foi observado o pico em 122 ppm.

A região de 140-160 ppm é referente à ressonância de carbonos aromáticos substituídos por oxigênio e nitrogênio como por exemplo: fenóis, éteres aromáticos ou aminas. Apesar de se ter utilizado uma menor massa da fração 30-100 KDa, verificou-se que ela apresenta um pico mais intenso em 154 ppm, estando de acordo com trabalhos realizados por Francioso et al. (2001), na referida fração o autor observou que este pico apresenta-se mais intenso para as frações de ácidos húmicos de menor tamanho molecular. O pico observado na região de 165-180 ppm è atribuído à carbono de ácidos carboxílicos, amida e esteres (CARVALHO, 2003). O pico na região de 194 ppm é atribuido a carbonos de aldeidos e cetonas Lu et al. (2000). 


\subsection{4 - Ressonância paramagnética nuclear (EPR)}

A espectroscopia de ressonância paramagnética eletrônica (EPR) é uma técnica utilizada para medir a quantidade de radicais livres em uma amostra de SH. Um parâmetro que pode influenciar altamente as propriedades e reatividades redox, das $\mathrm{SH}$, com muitos substratos orgânicos e inorgânicos em diferentes ambientes (SCOTT, 1998; CHEN, 2002).

As Figuras 10 e 11 apresentam os espectros de EPR da fração de SH filtrada a $0,45 \mu \mathrm{m}$. Estes espectros são representativos, com formatos parecidos aos das outras frações. A Tabela 4 apresenta os valores da quantidade de radicais livres por g de amostra.

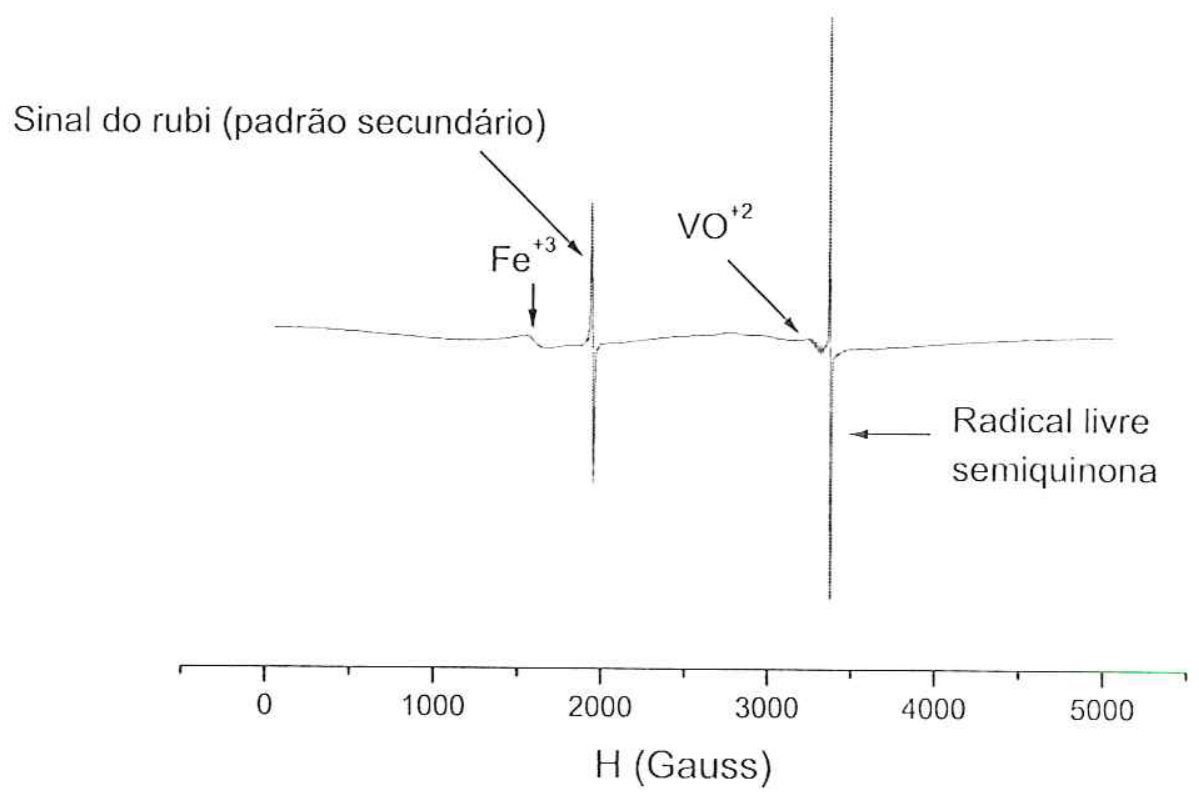

Figura 10 - Espectro de EPR para a fração de 0,45 $\mu \mathrm{m}$. 

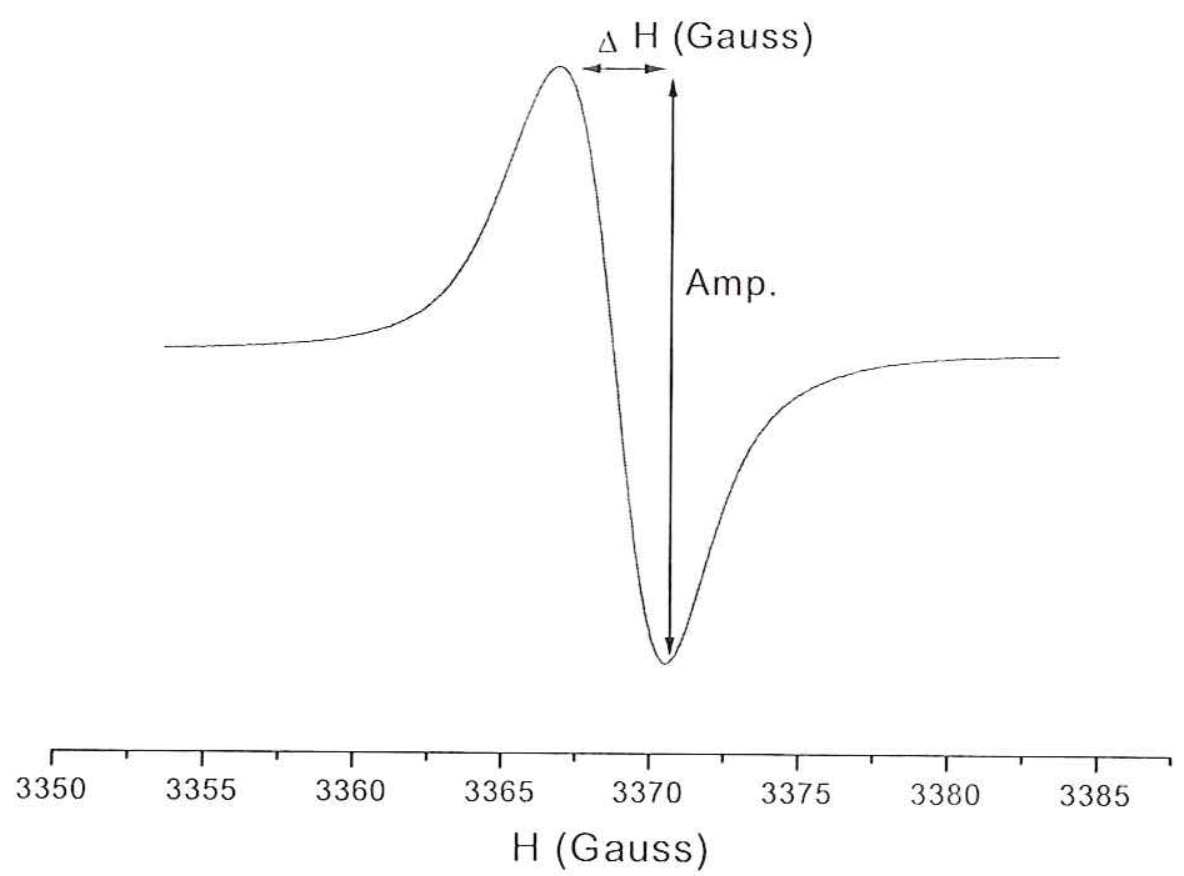

Figura 11- Espectro de EPR do radical livre semiquinona para a fração de 0,45 $\mu \mathrm{m}$.

Tabela 4- Valor da quantidade de radicais livres semiquinonas por massa (g) de cada fração.

\begin{tabular}{|c|c|c|}
\hline Fração & $\begin{array}{c}\text { Quantidade de radicais livres } \\
\text { spins/g }\end{array}$ & Fator g \\
\hline $30-100 \mathrm{KDa}$ & $1,40 \times 10^{18}$ & 2,0042 \\
\hline $100-0,45 \mathrm{KDa}$ & $2,87 \times 10^{18}$ & 2,0033 \\
\hline $0,45 \mathrm{um}$ & $2,61 \times 10^{18}$ & 2,0033 \\
\hline
\end{tabular}

Observa-se por meio dos espectros de EPR e pelos valores apresentados na Tabela 4 que a forma do sinal e os valores do fator $\mathrm{g}$ encontrados são devido a presença dos radicais livres semiquinonas apresentados na Figura 12. Essas características estão relacionadas com a presença de radicais livres semiquinonas naturais conjugados em um extenso sistema aromático. 


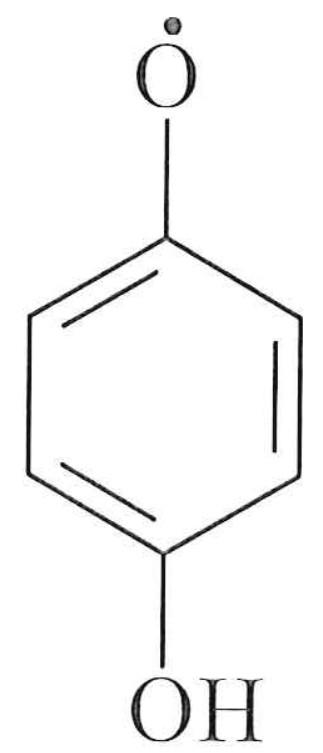

Figura 12- Radical livre semiquinona

Em todas as frações aparecem os sinais característicos das espécies $\mathrm{Fe}^{+3}$ com spin alto $5 / 2$ e g=4,3 e do $\mathrm{VO}^{+2} \mathrm{com}$ spin $7 / 2$, ligados a grupos funcionais das $\mathrm{SH}$. A quantidade de radicais livres encontrados diminui das frações de maior massa (>100 KDa) para a de menor (30-100 KDa). Isso pode ser uma indicação de que a fração de menor massa possui menor número de anéis aromáticos conjugados do que as de maior massa, o que foi confirmado pela razão $E_{4} / E_{6}$ já discutida no item (1.7.2). Outra indicação do nivel de condensação do material e assim a sua maior maturidade, é o número do fator g Jezierski et al. (2000). Em SH com maior grau de humificação e desta forma com maior número de grupos condensados, os valores de g são menores, como os valores encontrados para as frações de $0,45 \mu \mathrm{m}$ e $>100 \mathrm{kDa}$. O número de radicais livres também está diretamente relacionado com a quantidade de grupos fenólicos presentes nas $\mathrm{SH}$, ou seja, quanto maior o número de spins maior o número de grupos fenólicos (CAMPOS, 2004). 


\subsection{5 - Análise elementar}

A análise elementar é realizada com o objetivo de se conhecer a quantidade de elementos químicos que fazem parte da molécula polimérica. As frações das SH são diferenciadas pela quantidade de elementos químicos presentes na molécula: C, H, N, O (STEVENSON, 1982).

A relação H/C serve como indicação do grau de condensação ou como medida do estado de oxidação. Assim quanto menor for o valor de $\mathrm{H} / \mathrm{C}$ mais condensada encontra-se a estrutura (STEVENSON, 1982).

A relação $\mathrm{C} / \mathrm{N}$ é indicador de origem das $\mathrm{SH}$ em ambientes naturais.

Sabe-se que razões de $\mathrm{C} / \mathrm{N}$ abaixo de 20 indica que o processo de humificação foi. mais favorecido pela atividade microbiológica, como é verificado para SH extraídos das superfícies dos solos (CAMPOS, 2004).

Já para razões $\mathrm{C} / \mathrm{N}$ maiores que 20 é um indicador de que a contribuição para humificação do material é devido a predominância de plantas vasculares. $\mathrm{Na}$ Tabela 5 encontra-se apresentados os resultados da análise elementar para as frações das SH de diferentes tamanhos moleculares.

A razão O/C também é um indicativo do grau de condensação das estruturas, segundo (IBARRA, 1985) uma diminuição na razão O/C significa um aumento no número de anéis condensados.

Tabela 5 - Composição elementar das frações de diferentes tamanhos moleculares das $\mathrm{SH}$ e as razões atômicas dos elementos.

\begin{tabular}{|c|c|c|c|c|c|c|c|}
\hline Frações & \multicolumn{4}{|c|}{ Massa \% } & \multicolumn{3}{c|}{ Razões atômicas } \\
\hline & $\mathrm{C}$ & $\mathrm{H}$ & $\mathrm{N}$ & $\mathrm{O}^{*}$ & $\mathrm{H} / \mathrm{C}$ & $\mathrm{O} / \mathrm{C}$ & $\mathrm{C} / \mathrm{N}$ \\
\hline $0,45 \mu \mathrm{m}$ & 41,10 & 3,11 & 2,37 & 53,42 & 0,91 & 0,97 & 20,12 \\
\hline$>100 \mathrm{KDa}$ & 42,98 & 4,52 & 1,97 & 50,52 & 1,26 & 0,89 & 25,57 \\
\hline $30-100 \mathrm{KDa}$ & 31,89 & 5,92 & 1,83 & 60,35 & 2,22 & 1,42 & 27,54 \\
\hline
\end{tabular}

A porcentagem de $\mathrm{O}$ foi calculada por diferença

Analisando-se a Tabela 5, verifica-se que os contéudos de $\mathrm{C}, \mathrm{H}, \mathrm{N}$ e O, obtidos para as amostras aproximam-se de dados publicados na literatura, os que 
relatam uma distribuição elementar clássica na matéria orgânica, variando-se de $20-70 \%$ para o $\mathrm{C}$, de $0,1-5 \%$ para o $\mathrm{N}$ e de $3-8 \%$ para o $\mathrm{H}$ Calase et al. (1998). Comparando-se a fração de tamanho molecular maior que $100 \mathrm{KDa}$ com a fração entre 30 - $100 \mathrm{KDa}$, observa-se que a fração maior que 100 KDa apresenta uma menor razão H/C, o que indica que sua estrutura apresenta-se mais condensada do que a da fração entre 30 - $100 \mathrm{KDa}$, cujo resultado é comprovado pela razão $E_{4} / E_{6}$, já discutido no item anterior. Verifica-se também que ocorreu uma diminuição da porcentagem de C e um aumento da porcentagem de $\mathrm{O}$, o que indica que estas frações possuem uma concentração relativamente alta de $\mathrm{O}$ ligados a grupamentos alquílicos e carboxílicos (BELZILE, 1997). A fração 30 - 100 KDa apresenta uma maior razão O/C do que as demais frações, o que indica uma diminuição no número de anéis condensados (IBARRA, 1995). Todas as frações apresentaram uma razão C/N maior do que 20 o que indica que o material humificado foi originado de plantas vasculares.

\subsection{6 - Acidez total, carboxilica e fenólica}

Na Tabela 6 encontra-se apresentados os resultados dos grupos funcionais.

Tabela 6 - Caracterização química das frações das SH com base em grupos funcionais

\begin{tabular}{|c|c|c|c|}
\hline \multirow{2}{*}{ Frações das SH } & \multicolumn{3}{|c|}{ Grupos funcionais (mmol/g) } \\
\cline { 2 - 4 } & Acidez total & COOH & OH-fenólico \\
\hline $0-0,45 \mu m$ & 3,71 & 0,10 & 3,62 \\
\hline$>100 \mathrm{KDa}$ & 4,12 & 0,36 & 3,76 \\
\hline $30-100 \mathrm{KDa}$ & 6,18 & 0,63 & 5,55 \\
\hline
\end{tabular}

* Valor obtido por diferença entre acidez total e carboxilica.

Analisando-se os resultados apresentados na Tabela 6 , observa-se que a fração de tamanho molecular entre 30 - $100 \mathrm{KDa}$, possui um maior valor de acidez total e fenólica em relação as demais frações. Também observa-se que os contéudos dos grupos $\mathrm{OH}$ fenólico são mais abundantes que os grupos $\mathrm{COOH}$ em todas as frações estudadas. Estes resultados podem ser atribuídos a uma característica das frações de $\mathrm{SH}$, uma vez que, encontra-se na literatura alguns 
casos onde os grupos $\mathrm{OH}$ ácidos predominam sobre os carboxilicos Ussiri e Johnson (2003). Nas caracterizações realizadas por análise elementar discutidas no item (1.7.5), observou-se que fração de SH de tamanho molecular entre 30100 KDa apresenta uma maior porcentagem de oxigênio em sua estrutura. Também segundo estudos realizados por (CAMPOS, 2004) no qual foi caracterizadas as frações de SH de diferentes tamanhos moleculares, por RMN, notou-se que a fração de SH de tamanho molecular entre 30-100 KDa apresentou uma maior porcentagem de grupos oxigenados tais como carboxilicos, ésteres e fenólicos, o que vem a confirmar os resultados obtidos por titulação potenciométrica da acidez carboxílica e fenólica, na qual a fração 30-100 KDa apresentou um maior valor.

\section{$1.8-$ Conclusões}

Neste trabalho, técnicas espectroscópicas foram aplicadas para a análise das SH. Estas técnicas forneceram informações qualitativas e quantitativas de moléculas, compostos orgânicos e inorgânicos, presentes nas SH.

As SH utilizadas no trabalho são provavelmente originadas da degradação de plantas vasculares e não proveniente da degradação bacteriológica de algas ou de matéria orgânica, ou seja, as substâncias húmicas analisadas são alóctones.

A amostra de tamanho molecular entre 30-100 KDa apresenta um menor número de estruturas aromáticas e maior número de grupos oxigenados quando comparados as frações de tamanho molecular < 0,45 $\mu \mathrm{m}$ e maior que 100 KDa.

Os valores da razão $E_{4} / E_{6}$ indicam que a fração 0,45 um e $>100 \mathrm{KDa}$ encontram-se mais condensadas do que a fração de tamanho molecular 30-100 KDa o que foi confirmado pela análise elementar.

Foram identificados elevada concentrações de grupamentos carboxilicos e carbonilicos para a fração de tamanho molecular entre 30-100 KDa, sendo estes grupos os mais reativos com os oxidantes cloro e dióxido de cloro, podendo levar a uma alta formação de trialometanos e outros subprodutos da oxidação. 


\section{9 - CONSIDERAÇÕES A RESPEITO DO CAPÍTULO 1}

Neste capítulo foram determinadas às caracteristicas e propriedades estruturais das frações das substâncias húmicas (SH). A caracterização foi realizada com a finalidade de identificar grupos funcionais na estrutura, tais como carboxílicos e carbonílicos que poderiam reagir com os oxidantes cloro e dióxido de cloro, visto que os mecanismos propostos sugerem a interação do cloro e dióxido com estes grupos. Após feitas as caracterizações das frações das $\mathrm{SH}$, estas foram utilizadas no preparo da água utilizada nos ensaios de demanda que serão apresentados no capítulo 2. As frações serão utilizadas no preparo da água nos ensaios de oxidação e determinação dos subprodutos que constam do capítulo 4. 


\section{CAPITULO - 2}

\section{Ensaios de demanda com os oxidantes cloro e dióxido de cloro}

\section{2 - INTRODUÇÃO}

A água é a substância natural mais importante do mundo, sendo que sem ela a vida não poderia existir. As águas naturais contêm grande parte das substâncias e elementos facilmente absorvidos pelo organismo, constituindo, portanto fonte essencial de minerais ao desenvolvimento do ser humano (DANIEL, 2001).

Historicamente, a maioria das comunidades cresceram ao redor de rios e estas também tornaram-se o mais fácil depósito para os mais variados resíduos. Até os dias atuais, após o seu uso nas mais diversas atividades, a água ainda é geralmente descartada em corpos receptores mais próximos, muitas vezes sem que passe por qualquer tipo de tratamento, transformando-se em um potencial veículo para a contaminação da população (MEYER, 1994). No entanto, essas águas podem conter organismos patogênicos e poluentes que são prejudiciais à saúde humana.

Para que a água seja destinada ao consumo humano, esta deve preencher condições minimas para que possa ser ingerida ou utilizada para fins higiênicos, o que se consegue por meio de processos usados nas estações de tratamento tais como, pré-oxidação, coagulação, floculação, filtração e desinfecção (DI BERNARDO, 1995).

A desinfecção da água tem sido praticada por milênios, embora os princípios envolvidos no processo não fossem conhecidos. Existem indicios de que o uso da água fervida já era recomendado em 500 a.c., mas alguns historiadores julgam que está pratica era adotada desde o começo da civilização (MEYER, 1994). Até que a teoria dos microrganismos fosse estabelecida, havia a crença de que as doenças eram transmitidas através de odores. A desinfecção da água e dos efluentes surgiu como uma tentativa de se controlar a propagação das 
doenças através dos odores. O processo de desinfecção tem como objetivo a destruição ou inativação de organismos patogênicos, capazes de produzir doenças, ou de outros organismos indesejáveis (MEYER, 1994).

$\mathrm{Na}$ etapa de oxidação torna-se necessária a realização de ensaios de demanda, para determinar as dosagens dos oxidantes a serem utilizados na oxidação da água de estudo. Estes ensaios são realizados empregando-se. reatores jarteste, onde varia-se a dosagem empregada em função do tempo de contato. A demanda é definida como a dosagem aplicada menos o residual remanescente. Na etapa de pré-oxidação e desinfecção da água no Brasil, normalmente utiliza-se desinfetantes a base de cloro, sendo este adicionado nas formas de gás cloro e hipoclorito de sódio (MACÊDO,1997). Porém, na cloração das águas contendo matéria orgânica, ocorre a formação de trialometanos (THM) que são substâncias carcionogênicas Sanches et. al (2004). Os THM apresentam em sua estrutura molecular um átomo de carbono, um de hidrogênio e três de halogênios. Dentre os trialometanos, quatro são destacados, quando se fala em tratamento de água, devido à sua ocorrência em concentrações mais significativas, clorofórmio $\left(\mathrm{CHCl}_{3}\right)$, diclorometano $\left(\mathrm{CH}_{2} \mathrm{Cl}_{2}\right)$, dibromoclorometano $\left(\mathrm{CHBr}_{2} \mathrm{Cl}\right)$ e bromofórmio $\left(\mathrm{CHBr}_{3}\right)$ (MACÊDO, 1997). No sentido de minimizar a formação de trialometanos pode-se usar agentes desinfetantes alternativos.

Os agentes desinfetantes alternativos utilizados na europa são, ozônio, dióxido de cloro, peroxônio, porém deve-se levar em conta que qualquer que seja o desinfetante alternativo, deve-se garantir que seja efetivo na inativação de bactérias, vírus e protozoários entre outros organismos patogênicos e que não produza qualquer composto secundário que cause risco à saúde humana etc (DANIEL, 2001).

No Brasil, quase não se tem utilizado agentes desinfetantes alternativos, sendo que estes vêm sendo empregados somente nos centros de pesquisa para fins de investigação da eficiência, porque o custo destes agentes desinfetantes e superior ao do cloro e necessita-se de uma mão de obra especializada. 
2.1 - Evolução dos processos de cloração da água e uso de agentes desinfetantes alternativos

\subsection{1 -Evolução dos processos de cloração da água}

O Cloro foi descoberto em 1808 por Sir Humprey Davy e teve as suas propriedades bactericidas descobertas e investigadas sob condições de laboratório pelo bacteriologista Koch, em 1881. O uso do cloro foi aprovado pela Amerincan Public Heath (APHA) em 1886, para uso como desinfetante. A partir do inicio do século XIX, algumas regiões dos Estados Unidos já utilizavam este agente químico no processo de desinfecção de águas para abastecimento (CARVALHO, 2003).

O uso contínuo do cloro só ocorreu a partir de 1902, na Bélgica, com o chamado refinamento de cloração, isto é, determinação das formas de cloro combinado e livre e a cloração baseada em controle bacteriológico (MEYER, 1994). O uso de cloro na desinfecção da água foi iniciado com a aplicação do hipoclorito de sódio ( $\mathrm{NaOCl}$ ), obtido pela decomposição eletrolitica do referido sal (DI BERNARDO, 1995).

Inicialmente o cloro era empregado na desinfecção de águas somente em casos de epidemias. A partir de 1902, a cloração foi adotada de maneira contínua na Bélgica. Neste mesmo país em 1909, o cloro passou a ser utilizado e armazenado em cilindros revestidos com chumbo.

De acordo com (ROSSIN, 1987), os processos de cloração evoluiram com o tempo, e esta evolução pode ser caracterizadas em diferentes décadas:

r 1908 a 1918 - início da cloração das águas; aplicação de uma pequena quantidade de cloro;

r 1918 - 1928 - acentuada expansão no uso de cloro liquido;

r 1928 - 1938 - uso de cloraminas, adição conjunta de amônia e cloro, de modo a se obter um residual de cloraminas. Ainda não eram empregados testes específicos para se determinar os residuais de cloro; 
r 1948 a 1958 - refinamento da cloração; determinação das formas de cloro combinado e livre; e a cloração baseada em controles bacteriológicos.

\subsection{2 - Processo de cloração nas estações de tratamento de água (ETA)}

Quando um derivado clorado é adicionado à água, ocorre em primeiro lugar, a reação de oxidação da matéria orgânica, que recebe o nome de "demanda de cloro". Satisfeita esta demanda, o derivado clorado reage com a amônia, formando as cloraminas, que são denominadas de "cloro residual combinado". Após a formação de cloraminas, tem-se a presença do chamado "cloro livre", que é constituido do ácido hipocloroso e do ín hipoclorito (PROSAB, 2001).

Há basicamente três métodos de aplicação de cloro: a cloração simples, a amônia cloração e a cloração ao "break-point ou "ponto de quebra" (DI BERNARDO, 1995; DANIEL, 2001).

Na cloração simples não existe a preocupação de satisfazer a demanda, simplesmente aplica-se o derivado clorado, que ao fim de um determinado tempo de contato o residual deve estar entre 0,1 e $0,2 \mathrm{mg} \mathrm{L}^{-1}$, que é considerado suficiente para a garantia da qualidade em relação aos microrganismos que podem estar presentes (DANIEL, 2001).

Se o conceito da cloração simples for mal aplicado em águas poluidas, o cloro não apresentará efeito bactericida adequado, já que o derivado clorado será rapidamente consumido Richter e Azevedo Netto (1991).

A amônia-cloração corresponde à adição de amônia e do derivado clorado simultaneamente. Este processo é utilizado em águas que contêm matéria orgânica na forma de fenóis, evitando a formação dos chamados clorofenóis, que são responsáveis por odores e sabores desagradáveis. A escolha deste processo baseia-se no menor poder oxidante das cloraminas, bem como na sua maior estabilidade, conseguindo manter um residual na rede de distribuição, evitando contaminações no interior das canalizações e no armazenamento (DANIEL, 2001; RICTHER, 1991). 
Já a cloração ao "break-point" ocorre sob condições controladas, adicionando cloro até que a demanda seja satisfeita. O cloro continua a ser adicionado até que os compostos cloro-nitrogenados (cloraminas) também sejam oxidados, pois estes compostos são responsáveis por sabor e odor característicos dos derivados clorados (DANIEL, 2001).

$\mathrm{O}$ ponto em que o cloro adicionado libera somente $\mathrm{HClO}$ (ácido hipocloroso) e $\mathrm{ClO}^{-}$(ion hipoclorito), com a finalidade somente de desinfecção, é denominado ponto de quebra. O processo de desinfecção com a cloração ao "break-point" pode ser aplicado na pré-cloração, ou na pós-cloração. Na pré-cloração, a adição do derivado clorado faz-se antes de qualquer tratamento, ou seja, logo após a captação da água do manancial. Na pós-cloração, o derivado clorado é aplicado após o processo de filtração. Neste, o consumo de cloro é menor, pois grande quantidade de matéria orgânica é retirada pelo processo de clarificação, sedimentação com agentes floculantes, reduzindo a demanda de cloro (DI BERNARDO, 1995).

\subsection{3 - Cloraminas}

O cloro e seus compostos são fortes agentes oxidantes. Em geral a reatividade diminui com o aumento do $\mathrm{pH}$, e sua velocidade de reação aumenta com a elevação da temperatura (MEYER, 1994).

As reaçõe do cloro com compostos inorgânicos redutores, como sulfitos, sulfetos, ín ferroso e nitrito, são geralmente muito rápidas. Alguns compostos orgânicos dissolvidos também reagem rapidamente com o cloro, mas em geral são necessários algumas horas para que a maioria das reações do cloro com compostos orgânicos se complete. Quando o cloro adicionado à uma água quimicamente pura ocorre a reação da água com o cloro produzindo o ácido hipocloroso, o qual é responsável pela ação desinfetante e oxidante do cloro (MACÊDO, 2000.; SANCHES, 2003a) como apresenta a eq.(3):

$$
\mathrm{Cl}_{2}(\mathrm{~g})+2 \mathrm{H}_{2} \mathrm{O}(\mathrm{I})=\mathrm{HOCl}(\mathrm{I})+\mathrm{H}_{3} \mathrm{O}^{+}(\mathrm{ag})+\mathrm{Cl}^{-}(\mathrm{ag})
$$


O ácido hipocloroso por sua vez dissocia-se formando o ion hipoclorito, o qual não apresenta praticamente nenhum poder de desinfecção como apresenta a eq.(4):

$\mathrm{HOCl}(\mathrm{ag}) \rightleftharpoons \mathrm{H}^{+}(\mathrm{ag})+\mathrm{ClO}^{-}(\mathrm{ag})$

Essa reação é reversivel e o grau de dissociação é dependente do pH e da temperatura. Na faixa usual de $\mathrm{pH}$ da água de abastecimento, coexistem o ácido hipocloroso e o íon hipoclorito, definidos como cloro residual livre.

Por outro lado, o cloro sob a forma de ácido hipocloroso reage com a amônia e com compostos amoniacais inicialmente presentes ou intencionalmente adicionados na água, formando compostos clorados ativos chamados cloraminas. O cloro apresentado sob esta forma é denominado cloro residual combinado.

$\mathrm{O}$ cloro e a amônia combinam-se para formar a monocloramina $\left(\mathrm{NH}_{2} \mathrm{Cl}\right)$, a dicloramina $\left(\mathrm{NHCl}_{2}\right)$ e a tricloramina $\left(\mathrm{NCl}_{3}\right)$ segundo as eq. $(5,6,7)$ :

$$
\begin{aligned}
& \mathrm{NH}_{4}^{+}+\mathrm{HOCl} \rightleftharpoons \mathrm{NH}_{2} \mathrm{Cl}+\mathrm{H}_{2} \mathrm{O}+\mathrm{H}_{3} \mathrm{O}^{+} \\
& \mathrm{NH}_{2} \mathrm{Cl}+\mathrm{HOCl} \rightleftharpoons \mathrm{NHCl}_{2}+\mathrm{H}_{2} \mathrm{O} \\
& \mathrm{NHCl}_{2}+\mathrm{HOCl} \rightleftharpoons \mathrm{NCl}_{3}+\mathrm{H}_{2} \mathrm{O}
\end{aligned}
$$

A formação dos três tipos de cloraminas é dependente da relação cloro/nitrogênio, do $\mathrm{pH}$, da temperatura e do tempo de reação, sendo que a diminuição do $\mathrm{pH}$ e aumento da relação cloro/nitrogênio favorece a formação de produtos clorados. Em pH 8,5 a monocloramina encontra-se em maior quantidade. Em pH 4,4 toda cloramina se encontra na forma de tricloramina, cuja presença é responsável, em parte, pelo odor e gosto desagradáveis da água. Na faixa de $\mathrm{pH}$ 4,5 a 9,0, as monocloraminas e dicloraminas coexistem em proporções variadas. Por exemplo, entre $\mathrm{pH}$ 4,5 e 5,5 existe praticamente apenas dicloraminas. Essas quantidades de mono, di e tricloraminas são importântes já que apresentam entre si diferente poder de desinfecção: as dicloraminas exercem maior efeito 
bactericida, seguidas das monocloraminas, já que as tricloraminas praticamente não apresentam nenhum efeito desinfetante.

Para a aplicação das cloraminas como desinfetante primário em uma estação de tratamento de água, a amônia e o cloro são adicionados à água simultaneamente.

\subsection{4 - Uso de desinfetantes alternativos}

Historicamente, a desinfecção tem sido vista como a principal medida na prevenção de doenças infecciosas de transmissão hídrica (PROSAB, 2001). No Brasil, a desinfecção da água para consumo humano é usualmente realizada com adição de cloro nas formas de gás, hipoclorito de sódio ou hipoclorito de cálcio. Porém na etapa de cloração ocorre inconvenientes devido a interação do ácido hipocloroso com a matéria orgânica, o qual forma-se produtos carcinogênicos tais como os trialometanos. No sentido de minimizar a formação destes produtos tem havido um crescente interesse pelo uso de desinfetantes alternativos entre eles estão o dióxido de cloro, ozônio, peróxido de hidrogênio e permanganato de potássio, entre outros Sanches et al. (2004). Porém não se deve perder de vista o processo de desinfecção como um todo e nos atributos de um dado desinfectante que devem possuir as seguintes caracteristicas (SANTOS, 1988):

1 - Poder destruir, em um tempo razoável, os organismos patogênicos e serem eliminados, na quantidade em que se apresentarem e nas condições encontradas nas águas;

2 - Não devem ser tóxicos para o homem e para os animais domésticos e nas dosagens usuais, não devem causar à água odor e gosto que prejudiquem o seu consumo;

3 - Estar disponíveis a um custo razoável, apresentar facilidade e segurança no transporte, armazenamento, manuseio e aplicação;

4 - Concentração na água tratada fácil e rapidamente determinável, de preferência automática; 
5 - Produzir residuais resistentes na água de maneira a constituir uma barreira sanitária contra eventual recontaminação antes do uso.

Com relação ao item anteriormente relacionado cabe aqui acrescentar que, não só o desinfetante propriamente dito, mas também os subprodutos da desinfecção não devem ser tóxicos ao homem, a não ser que sejam removidos da água após sua formação por algum processo unitário adicional na estação de tratamento de água. Cabe salientar que, além do uso dos agentes desinfetantes alternativos, podem-se utilizar outros processos de desinfecção, tal como irradiação ultravioleta.

\subsubsection{1 - Dióxido de cloro}

A primeira aplicação de dióxido de cloro como desinfetante e oxidante ocorreu em 1944, na estação de tratamento de água de Niagara Falls (EUA). Sua aplicação para o tratamento de água de abastecimento tornou-se possivel devido à disponibilidade comercial do clorito de sódio, a partir do qual todo dióxido de cloro é produzido PROSAB (2001). O dióxido de cloro é gerado pela ativação de clorito de sódio $\left(\mathrm{NAClO}_{2}\right)$ com solução de ácido clorídrico $(\mathrm{HCl})$, segundo a eq.(8):

$$
5 \mathrm{NaClO}_{2}+4 \mathrm{HCl} \rightleftharpoons 4 \mathrm{ClO}_{2}+5 \mathrm{NaCl}+2 \mathrm{H}_{2} \mathrm{O}
$$

O seu uso é restrito em função dos problemas de estocagem, manuseio e por exigir capacitação técnica para sua utilização em decorrência do seu efeito explosivo o que leva à sua produção no próprio local de uso (RITTMANN, 1997).

O dióxido de cloro apresenta vantagens quando comparado aos demais compostos clorados. Possui maior estabilidade em água, hidrolisa compostos fenólicos, diminuindo a possibilidade de sabores e odores desagradáveis. Reage com menor intensidade com a matéria orgânica, apesar de ser cerca de 2,5 vezes mais oxidante do que o gás cloro e de apresentar boa ação esporicida (PROSAB, 2001). 
O dióxido de cloro é um desinfetante eficiente e, com baixo tempo de contato, é efetivo para o controle de sabor e odor, oxidação de ferro e manganês, não sendo exercida demanda adicional deste composto se a água bruta contiver amônia. O dióxido de cloro não produz quantidades significativas de subprodutos da desinfecção (SPD), exceto a formação de íons clorito e clorato em determinadas faixas de $\mathrm{pH}$, pois cerca de 50 a $70 \%$ do dióxido de cloro consumido é reduzido a clorito.

Segundo (Di Bernardo, 1995), os SPD formados em decorrência do uso de dióxido de cloro ainda não foram estudados convenientemente, também não é conhecido o efeito dos mesmos no ser humano. Recentemente, em estudo realizado por Chang et al. (2001), foi observada a presença de subprodutos (clorito e clorato) com dosagens de 1 a $10 \mathrm{mg}$ de $\mathrm{ClO}_{2} \mathrm{~L}^{-1}$, sendo que o máximo permitido é de $0,2 \mathrm{mg} \mathrm{L}^{-1}$ de clorito (DANIEL, 2001).

\subsubsection{2 - Permanganato de Potássio}

O permanganato de potássio foi introduzido no tratamento de água por Alexander Houston em Londres no ano de 1913. Ele é um oxidante eficiente para o controle de sabor e odor da água de consumo, para a oxidação de uma grande variedade de compostos orgânicos e inorgânicos tais como o de Fe e Mn, especialmente quando esses metais encontram-se complexados com a matéria orgânica natural, e também é utilizado no controle de algas em decantadores (CHAMBERS, 1956). O permanganato de potássio pode ainda ser utilizado para controlar a formação de trialometanos e outros subprodutos da desinfecção através da oxidação dos precursores e diminuição da demanda de outros desinfetantes (EPA, 1999).

O permanganato de potássio é o segundo pré-oxidante mais utilizado em plantas de tratamento de águas superficiais nos Estados Unidos da América, onde é empregado em $16 \%$ do número total de ETA enquanto o cloro é empregado em $68,8 \%$ (EPA, 1999). O permanganato de potássio é altamente reativo e pode inativar várias bactérias e vírus, entretanto, não é empregado como desinfetante 
primário ou secundário quando aplicado em doses comumente utilizada em tratamento de água. Altas doses têm elevados custos, além disso o residual de permanganato de potássio deixa a água rosada (DI BERNARDO, 1995; DANIEL, 2001). Não se conhece até hoje nenhum subproduto formado gerado pelo uso do permanganato de potássio (DANIEL, 2001). Porém sabe-se que o pré-tratamento com permanganto em combinação com a pós-cloração fornecem menores concentrações de subprodutos que nos casos em que se aplicava a pré-cloração (EPA, 1999).

\subsubsection{3 - Ozônio}

O ozônio é uma forma alotrópica do oxigênio, não apresenta odor peculiar, é muito volátil e pouco solúvel em água, sendo pouco estável (PROSAB, 2001). Foi utilizado pela primeira vez, no tratamento de água, em 1840. Desde 1898, em Paris, a água vem sendo tratada com ozônio e data de 1924 o registro de uso de ozônio em várias cidades da França e da Alemanha (DANIEL, 2001).

O ozônio é um potente oxidante, capaz de oxidar compostos orgânicos e inorgânicos na água, os quais exercerão uma demanda do oxidante antes de ocorrer a desinfecção (EPA, 1999). Decompõe-se na água espontaneamente por meio de mecanismos complexos que envolvem a geração de radicais livres como hidroxilas $(\mathrm{OH})$. Os dois mecanismos de reação do ozônio na água são (DANIEL, 2001.; SANCHES, 2003b):

- oxidação direta dos compostos pelo ozônio molecular $\left(\mathrm{O}_{3(\mathrm{ag})}\right)$;

- oxidação dos compostos pelos radicais livres hidroxilas produzidos durante a decomposição do ozônio.

O ozônio se decompõe com rapidez, principalmente em temperaturas relativamente elevadas. Na sua aplicação, perde-se cerca, de 10\% por volatilização. As principais vantagens do uso do ozônio segundo Blatchley III e Xie (1995) são:

- redução de sabor, odor e cor;

- é um poderoso oxidante, com atuação rápida sobre a matéria orgânica; 
- ação rápida sobre bactérias;

- a não existência de riscos à saúde humana em casos de doses excessivas;

- oxida fenóis, detergentes e pigmentos presentes na água;

- rápida ação desinfetante, sendo o tempo de contato suficiente para desinfecção de 5 a 10 minutos;

- a ozonização pode ser combinada com a pós-cloração, para eliminar problemas organolépticos decorrentes da existência de material orgânico. produtor de gosto e odor.

Como principais desvantagens citam-se Chang et al. (2001): (i) é um gás venenoso, que não apresenta odor nem cor perceptivel, tendo como concentração máxima permissivel desse gás na atmosfera de $0,1 \mathrm{mg} \cdot \mathrm{m}^{-3}$ Rucco Jr et al. (1981), necessitando de mão-de-obra especializada para sua manipulação; (ii) não existem técnicas analíticas suficientemente específicas ou sensiveis para o controle de seu residual de forma imediata e eficiente após sua aplicação; (iii) os custos operacionais, onde incluem energia elétrica, instalação e operação são altos, em torno de 10 a 15 vezes superiores ao uso do cloro Blacthley III e Xie (1995).

A Organização Mundial da Saúde (OMS) não recomenda o uso de ozônio em águas que contenham brometos, pois estes são oxidados a bromatos, que são considerados cancerígenos (GRAY, 1994). Na ozonização, conforme dados das pesquisas realizadas por (GRAY, 1994) ocorre uma menor formação de subprodutos do que na cloração.

\subsubsection{4 - Peróxido de Hidrogênio}

O peróxido de hidrogênio é usado como pré-oxidante conjuntamente com ozônio e com o ácido peracético. O principal uso do peróxido de hidrogênio é no tratamento de água destinada ao consumo humano com o objetivo de controlar ou eliminar algas ou oxidar o ferro e o manganês presentes até os teores limitados pela legislação, que é de 0,3 e 0,1 mg..-1 , respectivamente (DANIEL, 2001). Este reagente tem sido utilizado em conjunto com o ozônio, pois ocorre um acréscimo 
na concentração de radicais hidroxilas $(\mathrm{OH})$ em relação ao processo de ozonização, aumentando o potencial de oxidação e desinfecção (DANIEL, 2001).

\subsubsection{5 - Ácido peracético}

$\mathrm{O}$ ácido peracético $\left(\mathrm{CH}_{3} \mathrm{COOOH}\right)$, é um liquido incolor, com odor acre, tóxico e explosivo acima de $110^{\circ} \mathrm{C}$. Pode ser extremamente irritante à pele, olhos e trato respiratório (DANIEL, 2001). Não há registros na literatura de que o ácido peracético possa ser cancerígeno ou apresentar toxicidade na reprodução e desenvolvimento humano (DANIEL, 2001). O seu principal uso tem sido como desinfetante em indústrias alimentícias (laticinios e frigorificos), como agente bactericida, virucida, esporicida e fungicida. Na agricultura, é usado como germicida na pulverização de frutas e vegetais, sendo empregado, ainda, na esterilização de equipamentos de uso cirúrgico e hospitalar em geral. As informações disponíveis na literatura são, em sua maioria, sobre o uso deste na desinfeç̧ão de efluentes domésticos, com dosagens de $5 \mathrm{mg} \mathrm{L}^{-1}$. e tempo de contato de 27 minutos, com remoção de 99,40\% de coliformes fecais (DANIEL, 2001). Recentemente tem sido introduzido como desinfetante em estações de tratamento de água.

Na água, o ácido peracético decompõe-se em oxigênio e ácido acético, ele é eficiente em ampla faixa de $\mathrm{pH}$ e temperatura, não introduz ou altera o sabor, odor e cor da água (DANIEL, 2001). Este ácido é formado pela reação de ácido acético e peróxido de hidrogênio, de acordo com a eq.(9):

$$
\mathrm{H}_{2} \mathrm{O}_{2}+\mathrm{CH}_{3} \mathrm{COOH} \rightarrow \mathrm{CH}_{3} \mathrm{COOOH}+\mathrm{H}_{2} \mathrm{O}
$$

Em água de abastecimento, a aplicação é mais comum como pré-desinfecção para melhorar a qualidade da água bruta, com a vantagem de se reduzir a quantidade de patógenos e de matéria orgânica, reduzindo também o potencial de formação de subprodutos clorados (DANIEL, 2001). Não se tem, 
ainda, dados sobre a potencialidade de formação de subprodutos com o uso de ácido peracético após um longo tempo de contato.

\subsubsection{6 - Ultravioleta (UV)}

O processo físico de desinfeccão por exposição à radiação UV é capaz de inativar quase todos os microorganismos encontrados em água, principalmente bactérias e coliformes. Sua utilização é recente, sendo questionada pela não manutenção de residual, permitindo futuras recontaminações da água.

Segundo (DANIEL, 2001) as principais vantagens da utilização da radiação ultravioleta como agente desinfetante em tratamento de água são:

- simplicidade e baixos custos de operação e manutenção, o equipamento de radiação ultravioleta é mais simples do que os de geração de ozônio e de dióxido de cloro;

- a radiação ultravioleta é efetiva para grande variedade de bactérias e vírus, usando doses relativamente pequenas;

- pequeno tempo de contato;

As principais desvantagens apresentadas da desinfecção de água empregando-se a radiação ultravioleta são (DANIEL, 2001):

- não confere residual à água distribuída, o que permite a recontaminação; 


\section{2 - OBJETIVOS}

Determinação da demanda de cloro e dióxido de cloro necessária para a oxidação das SH presente em uma água de cor verdadeira de $100 \pm 6 \mathrm{uH}$.

\section{3 - PARTE EXPERIMENTAL}

\subsection{1 - Construção da curva de calibração de cor em relação ao pH}

Para a realização das curvas de calibração foi utilizado um espectofotometro DR/4000 U da marca Hach. Estas curvas foram feitas utilizando-se as SH extraidas. Os valores da cor foram obtidos por meio de uma curva padrão seguindo-se o procedimento descrito no Standards Methods (1998) e que está apresentado a seguir:

Dissolveu-se $1,246 \mathrm{~g}$ de cloroplatinato de potássio, $\mathrm{K}_{2} \mathrm{PtCl}_{6}$ (equivalente para $500 \mathrm{mg}$ de potássio metálico) e $1,00 \mathrm{~g}$ de cloreto de cobalto cristalizado, $\mathrm{CoCl}_{2} \cdot 6 \mathrm{H}_{2} \mathrm{O}$ (equivalente para $250 \mathrm{mg}$ de cobalto metálico) em água destilada com $100 \mathrm{~mL}$ de $\mathrm{HCl}$ concentrado e diluiu-se para $1000 \mathrm{~mL}$ com água destilada. Esta solução padrão possui cor de 500 unidades mg Pt Co.L ${ }^{-1}$.

Determinou-se no espectrofotômetro DR/4000 U da Hach em qual comprimento de onda ocorria a maior absorção. Observou-se um pico com maior intensidade no comprimento de onda de $455 \mathrm{~nm}$.

Utilizando-se essa solução padrão fez diluições sucessivas e com os valores da absorbância plotou-se uma curva padrão no equipamento DR/4000 U da Hach para ser utilizada nas medições de cor.

Assim utilizando-se a curva padrão de cor pode-se fazer a curva para as SH no $\mathrm{pH}$ 6,5 e 7,0 empregando-se diluições sucessivas. Esta faixa de $\mathrm{pH}$ foi selecionada por ser $\mathrm{o} p \mathrm{H}$ de todos os ensaios que serão realizados no equipamento jartest. Para a correção do $\mathrm{pH}$ foram utilizadas soluções de ácido cloridrico e hidróxido de sódio 1\%. Nas Figuras 13 e 14 encontram-se apresentadas as curvas de calibrações de cor para as $\mathrm{SH}$ em relação ao pH. 


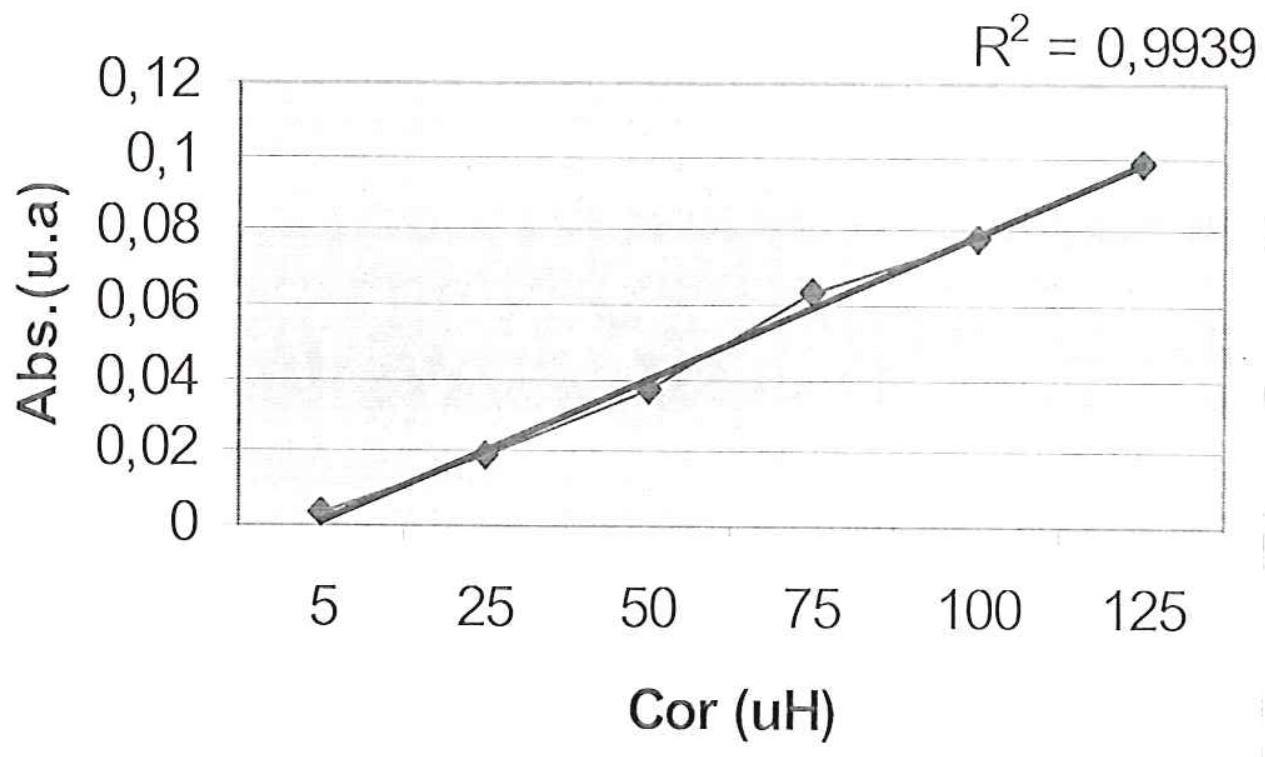

Figura 13 - Curva de calibração de cor das substâncias húmicas para pH 6,5.

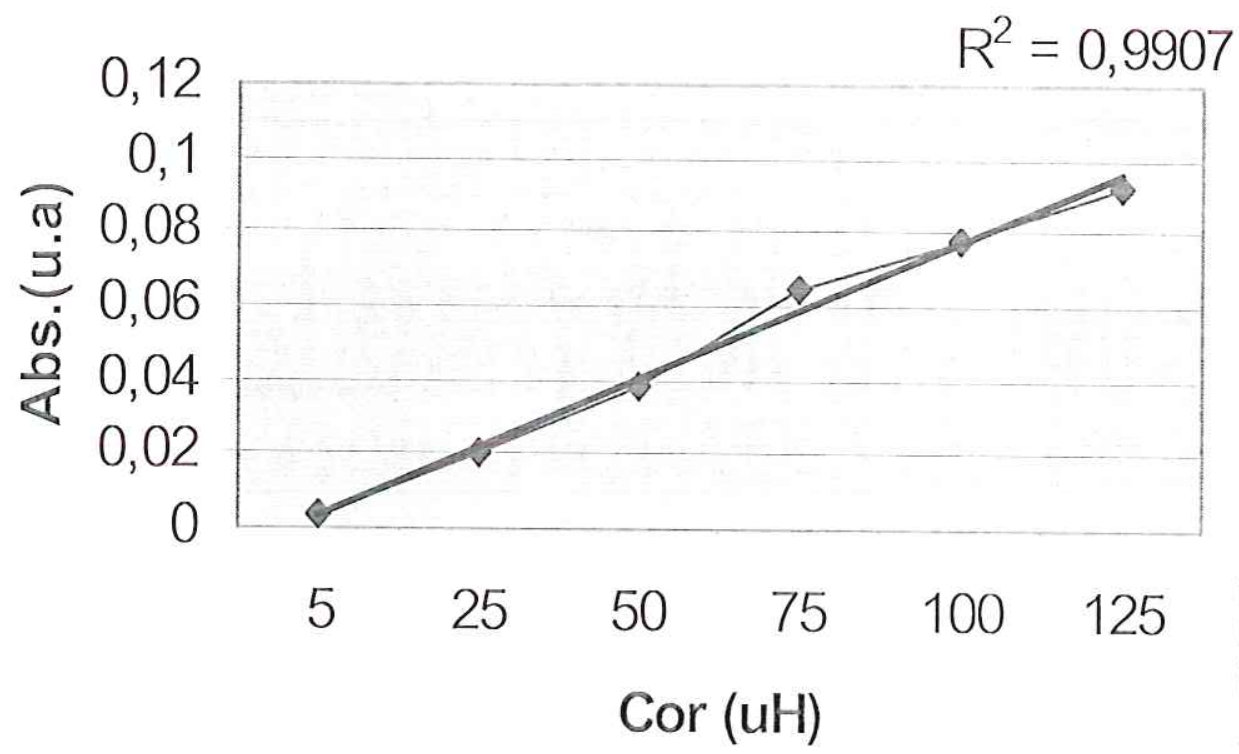

Figura 14 - Curva de calibração de cor das substâncias húmicas para pH 7,0. 
Pode-se observar nas Figuras 13 e 14, que os valores de $R^{2}$, estão próximos de 1,0 o que indica que há uma boa linearidade entre os pontos da curva.

\subsection{4 - Característica da água utilizada nos ensaios de pré-oxidação}

Na Tabela 7 encontram-se apresentadas as caracteristicas gerais da água do poço.

Tabela 7 -Características físicas e químicas da água do poço artesiano da Escola de Engenharia de São Carlos utilizada na preparação da água de estudo.

\begin{tabular}{c|c}
\hline Parâmetros & Valores \\
\hline Turbidez $(\mathrm{uT})$ & $<0,2$ \\
\hline Cor aparente $(\mathrm{uT})$ & $<2$ \\
\hline $\mathrm{pH}$ & 6,4 a 6,6 \\
\hline Ferro $\left(\mathrm{mg} \mathrm{L}^{-1}\right)$ & $<0,05$ \\
\hline Manganês $\left(\mathrm{mg} \mathrm{L}^{-1}\right)$ & $<0,01$ \\
\hline Cromo $\left(\mathrm{mg} \mathrm{L}^{-1}\right)$ & Não detectado \\
\hline Cádmio $\left(\mathrm{mg} \mathrm{L}^{-1}\right)$ & Não detectado \\
\hline Cobalto $\left(\mathrm{mg} \cdot \mathrm{L}^{-1}\right)$ & Não detectado \\
\hline Níquel $\left(\mathrm{mg} \mathrm{L}^{-1}\right)$ & Não detectado \\
\hline Alumínio $\left(\mathrm{mg} \mathrm{L}^{-1}\right)$ & Não detectado \\
\hline Zinco $\left(\mathrm{mg} \mathrm{L}^{-1}\right)$ & Não detectado
\end{tabular}

\subsection{5 - Preparo da água de estudo}

A água de estudo foi preparada utilizando-se uma água não clorada coletada no poço artesiano localizado no campus da USP de São Carlos cujas caracteristicas foram descritas no item 2.3.4.

Preparou-se três tipos de água, a primeira água foi preparada adicionandose o extrato das substâncias húmicas filtradas em papel de filtro $0,45 \mu \mathrm{m}$. As demais foram adicionadas substâncias húmicas de tamanho molecular entre 30- 
$100 \mathrm{KDa}$ e a outra SH de tamanho molecular maior que $100 \mathrm{KDa}$. A cor da água foi conhecida comparando-se esta com as curvas padrões de PtCo decritas no item 2.3.1 levantada no equipamento DR4000 a um pH entre 6,5 e 7,0 obtendo-se cor aparente de $100 \pm 6 \mathrm{uH}$.

\subsection{6 - Ensaios com o oxidante cloro}

\subsubsection{1- Solução de cloro utilizada no ensaio}

Para preparação da solução de cloro foi utilizado o produto comercial orgânico tricloro-s-triazina-triona.

Antes de iniciar os ensaios, determinou-se o teor de cloro ativo da solução por titulação, utilizando-se o método iodometrico $4500-\mathrm{Cl}$ B, descrito no (STANDARTS METHODS, 1988).

\subsubsection{2 - Ensaios de demanda com o oxidante cloro}

A demanda é a quantidade consumida do pré-oxidante durante determinado tempo de reação, que é calculada subtraindo-se o valor medido do residual do valor da concentração do oxidante aplicada na água.

Os ensaios para a determinação demanda de cloro foi realizado para se obter os valores das concentrações necessários para a pré-oxidação da água de estudo com presença de substâncias húmicas.

Estes ensaios foram realizados no equipamento jarteste localizado no Departamento de Hidraúlica e Saneamento da USP de São Carlos, e encontra-se apresentado na Figura 15.

Completou-se cada jarro com capacidade de dois litros com a água de estudo preparada, em seguida mediu-se a temperatura e acionou-se a rotação das pás do equipamento até $45 \mathrm{rpm}$. Depois adicionou-se a quantidade de pré-oxidante necessária em cada um dos jarros, acionando-se o cronômetro. As concentrações nos jarros do pré-oxidante foram de 1,0 a 
$12,0 \mathrm{mg} \mathrm{L}^{-1}$ e os tempos de coleta das amostras referentes a cada um dos jarros foram de $10 ; 30 ; 60 ; 90$ e 120 minutos. A concentração de cloro foi determinada com base nos residuais obtidos de cloro em função do tempo de reação. Após os 120 minutos de ensaio foram medidas o $\mathrm{pH}$ e a cor da água final em cada um dos jarros. Os residuais de cloro foram medidos conforme procedimento descrito no item a seguir (2.3.6.3).

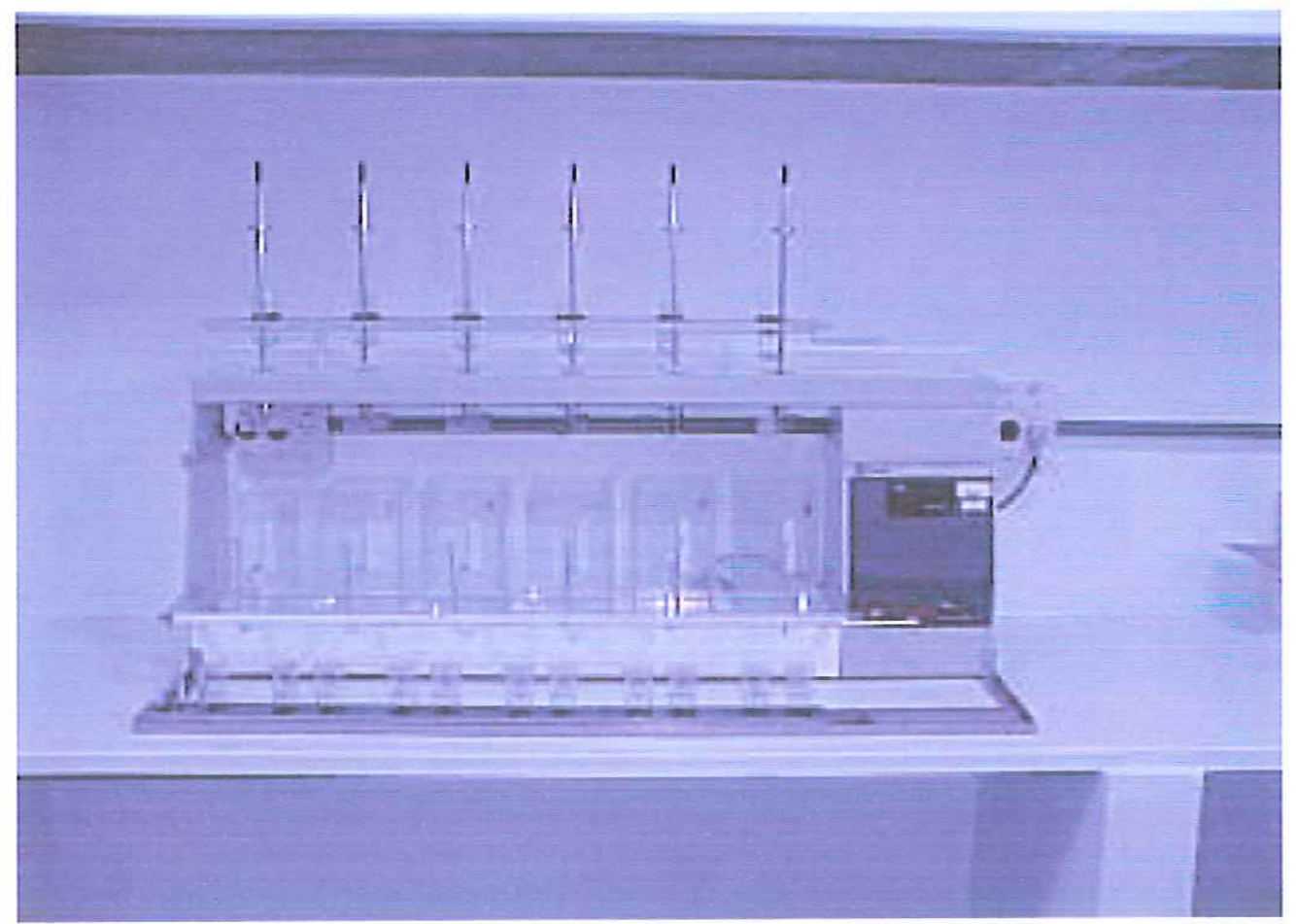

Figura 15 - Equipamento de "jartest" que foi utilizado nos ensaios de oxidação (CARVALHO, 2003).

\subsubsection{3 - Determinação do cloro livre}

As leituras foram realizadas no espectrofotômetro da marca Hach modelo DR 4000, o método utilizado foi o colorimétrico. A concentração de cloro, livre na solução foi determinada realizando-se a leitura a $530 \mathrm{~nm}$, sendo o resultado fornecido em $\mathrm{mg} \mathrm{L}^{-1}$ de $\mathrm{Cl}_{2}$. 


\subsection{7 - Ensaios com o oxidante dióxido de cloro}

\subsubsection{1 - Obtenção do dióxido de cloro}

O dióxido de cloro foi obtido pela ativação de clorito de sódio $\left(\mathrm{NaClO}_{2}\right)$ com solução de ácido clorídrico $(\mathrm{HCl})$. O clorito de sódio com ácido clorídrico, produzem uma solução aguosa de $\mathrm{ClO}_{2}$, como apresenta a eq.(10).

$$
5 \mathrm{NaClO}_{2}+4 \mathrm{HCl} \rightleftharpoons 4 \mathrm{ClO}_{2}+5 \mathrm{NaCl}+2 \mathrm{H}_{2} \mathrm{O}
$$

Para a obtenção do dióxido de cloro utilizou-se um gerador de modelo Bello Zon®, que está apresentado na Figura 16. Este equipamento pertence ao Departamento de hidráulica e Saneamento, da Escola de Engenharia de São Carlos da USP.

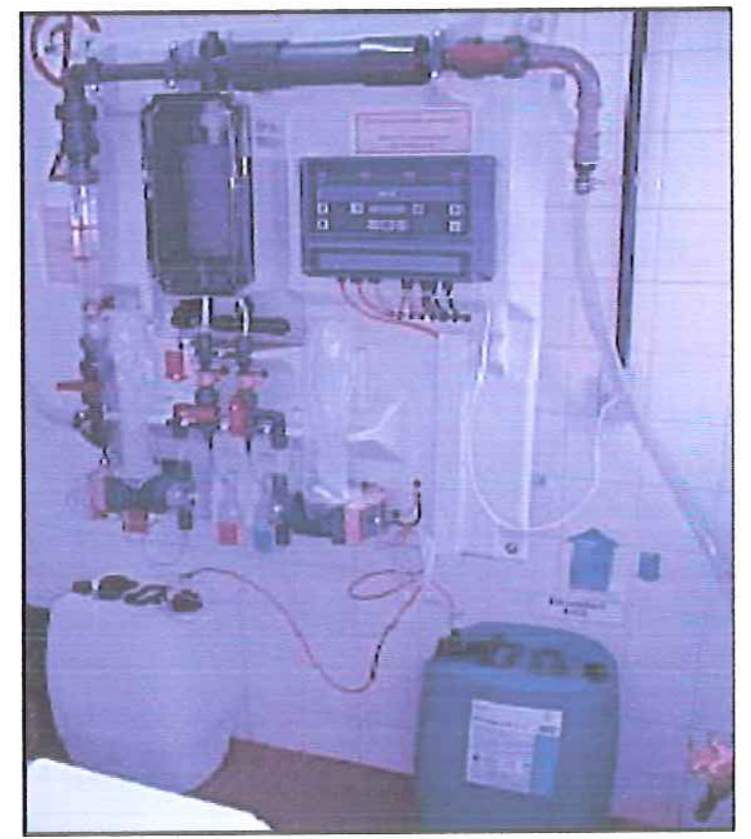

Figura 16 - Gerador de dióxido de cloro modelo Bello Zon® CDVa (CARVALHO, 2003). 
Capitulo 2

O gerador utilizado foi um Modelo CDVA, que apresenta as seguintes características:

Taxa de produção 35 - $2000 \mathrm{~g} / \mathrm{h}$.

Bello Zon® CDVa trabalha com produtos químicos diluidos, utilizando ácido clorídrico na concentração de $9 \%$ e clorito de sódio a 7,5\%. Um litro de cada um desses reagentes químicos forma 40 gramas de dióxido de cloro.

2.3.7.2 - Determinação da demanda e residual de dióxido de cloro

Para a determinação do dióxido de cloro livre e residual, utilizou-se o método colorimétrico. Determinou-se a concentração de cloro livre, na solução a $530 \mathrm{~nm}$, sendo o resultado fornecido em $\mathrm{mg} \mathrm{L}^{-1}$ de $\mathrm{Cl}_{2}$. A concentração obtida foi multiplicada por um fator de conversão de 1,9 para a determinação do residual de dióxido de cloro. A demanda é a quantidade consumida do oxidante durante determinado tempo de reação. Ela é calculada subtraindo-se o valor do residual medido do valor da dosagem do oxidante aplicada na água.

\section{4 - RESULTADOS E DISCUSSÃO}

2.4.1 - Ensaios para determinar a concentração de dióxido de cloro "demanda de dióxido de cloro" a serem utilizadas nos ensaios de formação dos subprodutos clorados.

$\mathrm{Na}$ Tabela 8 encontram-se apresentados os resultados dos ensaios de oxidação com o pré-oxidante dióxido de cloro, de uma água preparada com SH de tamanho molecular menor que $0,45 \mu \mathrm{m}$. 
Tabela 8 - Ensaios de pré-oxidação com dióxido de cloro, cuja água foi preparada com SH de tamanho molecular de 0- 0,45 $\mu \mathrm{m}$.

\begin{tabular}{|c|c|c|c|c|c|c|}
\hline \multirow{2}{*}{$\begin{array}{l}\text { Condições do ensaio: } \\
\text { Cor da água: } 105 \mathrm{uH} \\
\text { pH da água de estudo: } 6,4 \\
\text { rotação: } 45 \mathrm{rpm}\end{array}$} & \multicolumn{6}{|c|}{$\begin{array}{c}\text { Dosagens do oxidante dióxido utilizadas } \\
\text { no ensaio }\left(\mathrm{mg} \mathrm{L}^{-1}\right)\end{array}$} \\
\hline & 0,25 & 0,5 & 0,75 & 1,0 & 1,5 & 2,0 \\
\hline $\mathrm{pH}$ final após $120 \mathrm{~min}$ & 6,59 & 6,49 & 6,45 & 6,43 & 6,34 & 6,32 \\
\hline Cor final após $120 \mathrm{~min}$ & 96 & 93 & 88 & 84 & 82 & 77 \\
\hline Residual de $\mathrm{ClO}_{2}\left(\mathrm{mg} \cdot \mathrm{L}^{-1}\right) 10 \mathrm{~min}$ & 0,114 & 0,095 & 0,152 & 0,266 & 0,589 & 0,95 \\
\hline Demanda de $\mathrm{ClO}_{2}$ em $10 \mathrm{mim}$ & 0,136 & 5 & 8 & 4 & 1 & 1,05 \\
\hline Residual de $\mathrm{ClO}_{2}\left(\mathrm{mg} \cdot \mathrm{L}^{-1}\right) 30 \mathrm{~min}$ & 0,057 & 0,247 & 0,133 & 0,247 & 0,532 & 0,798 \\
\hline Demanda de $\mathrm{ClO}_{2} 30 \mathrm{mim}$ & 0,193 & 0,253 & 0,617 & 0,753 & 0,968 & 1,202 \\
\hline Residual de $\mathrm{ClO}_{2}\left(\mathrm{mg} \mathrm{L}^{-1}\right) 60 \mathrm{~min}$ & 0,057 & 0,076 & 0,114 & 0,114 & 0,171 & 0,418 \\
\hline Demanda de $\mathrm{ClO}_{2}$ em $60 \mathrm{mim}$ & 0,193 & 0,424 & 0,636 & 0,886 & 1,329 & 1,582 \\
\hline Residual de $\mathrm{ClO}_{2}(\mathrm{~m}$ & 0,057 & 0,057 & 0,095 & 0,057 & 0,133 & 0,266 \\
\hline Demanda de $\mathrm{ClO}_{2}$ em $90 \mathrm{mim}$ & 0,193 & 0,443 & 0,655 & 0,943 & 1,367 & 1,734 \\
\hline Residual de $\mathrm{ClO}_{2}\left(\mathrm{mg} \cdot \mathrm{L}^{-1}\right) 120 \mathrm{~min}$ & 0,038 & 0,038 & 0,057 & 0,038 & 0,095 & 0,152 \\
\hline Demanda de $\mathrm{ClO}_{2}$ em $120 \mathrm{mim}$ & 0,212 & 0,462 & 0,693 & 0,962 & 1,405 & 1,848 \\
\hline
\end{tabular}

Analisando-se a Tabela 8, observou-se que ao aumentar a dosagem de de dióxido de cloro, ocorre uma maior redução da cor. Segundo Richardson et al. (1994) o dióxido de cloro reduz significamente a cor e o odor de efluentes. Segundo Chang et al. (2001), quanto maiores forem as concentrações deste oxidante, aumentam-se a possibilidade das reações do dióxido de cloro com os grupos $\left(-\mathrm{OH}, \mathrm{O}-\mathrm{CH}_{3}\right)$, os quais compõem a estrutura das $\mathrm{SH}$. Então a oxidação destes grupos e de outras estruturas moleculares responsáveis pela cor da água como, hidroxil $(\mathrm{R}-\mathrm{OH})$, carbonil $(-\mathrm{CO})$, carboxil $(\mathrm{COOH})$, fenólicos e quinonas, promovem uma diminuição da cor da água. Em estudos realizados por (CARVALHO, 2004), utilizando-se a técnica de fluorecência com luz-visivel, foi verificado que quanto maior for a concentação do oxidante, mais rápido ocorre o processo de oxidação da matéria orgânica, o vem a proporcionar a diminuição da cor da água. 
Com relação ao pH, observou-se que ocorreu uma pequena variação do pH após as duas horas de ensaio, na qual foram utilizadas dosagens de dióxido de cloro no intervalo de 0,25 a 2,0 $\mathrm{mg} \mathrm{L}^{-1}$, como apresenta a Tabela 8 . O aumento do $\mathrm{pH}$ em relação ao $\mathrm{pH}$ da água de estudo, pode ser devido a redução do oxidante dióxido de cloro a íon clorito, o qual foi hidrolisado, e ocasionou um aumento da concentração do íon hidroxila como apresenta a eq.(11) e a eq.(12).

$\mathrm{ClO}_{2}(\mathrm{aq})+\mathrm{e}^{-} \rightarrow \mathrm{ClO}_{2}^{-}(\mathrm{aq})$
$\mathrm{ClO}_{2}^{-}(\mathrm{aq})+2 \mathrm{H}_{2} \mathrm{O}+4 \mathrm{e}^{-} \rightarrow \mathrm{Cl}^{-}(\mathrm{aq})+4 \mathrm{OH}^{-}$

Na Figura 17 encontra-se apresentado o gráfico de variação do residual de $\mathrm{ClO}_{2}$ em função da dosagem do oxidante, com dados extraídos da Tabela 8.

O residual de um oxidante é medido pela quantidade do oxidante disponivel, ou seja, tal medida é realizada após a aplicação de uma dosagem determinada do oxidante depois de trancorrido um certo tempo de reação.

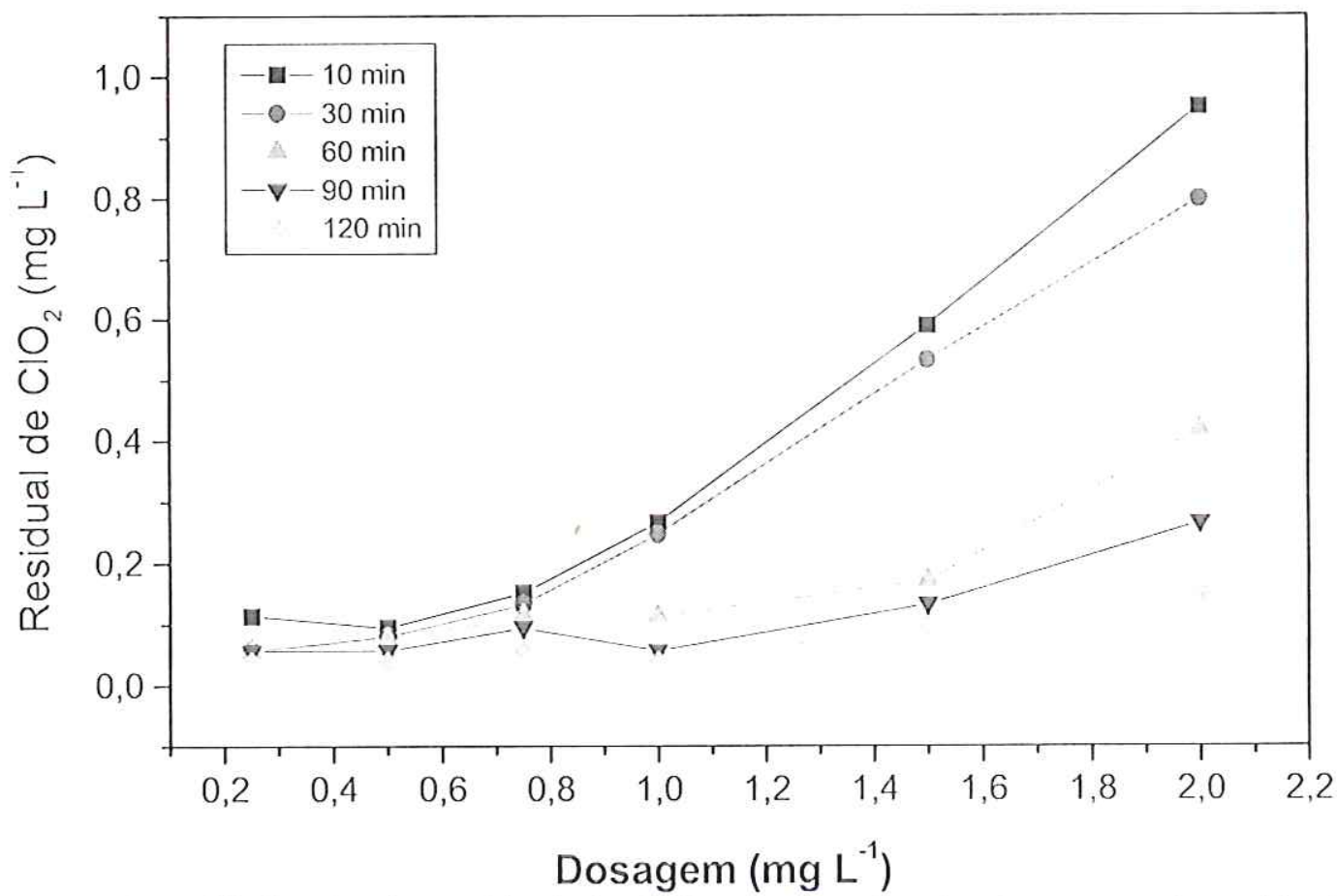

Figura 17. Variação do residual de $\mathrm{ClO}_{2}$ em função da dosagem do oxidante, água do ensaio preparada com a fração de $\mathrm{SH}$ de tamanho molecular entre $0-45 \mu \mathrm{m}$. 
Analisando-se a Figura 17 pode-se observar que ocorre uma diminuição da concentração de $\mathrm{ClO}_{2}$, a medida que aumenta-se o tempo da reação, tempo de contato. Esta redução foi observada para todas as dosagens de $\mathrm{ClO}_{2}$ utilizadas nos ensaios, sendo esta diminuição mais acentuada durante os dez primeiros minutos da reação. Observa-se que após os 120 minutos de ensaio, tem-se um residual baixo de $\mathrm{ClO}_{2}$, o que ocorre quando foram utilizadas baixas dosagens de $\mathrm{ClO}_{2}$. Este comportamento deve-se ao consumo do oxidante $\mathrm{ClO}_{2}$, pelas substâncias húmicas dissolvidas na água, o que vem a proporcionar uma diminuição da cor da água (RIOS, 2004). Segundo Korn et al. (2002), a concentração do residual de $\mathrm{ClO}_{2}$ não pode ser superior a $0,80 \mathrm{mg} \mathrm{L}^{-1}$. Analisando-se a Tabela 8 , observou-se que após as duas horas de ensaio, os residuais de $\mathrm{ClO}_{2}$ foram menores que $0,80 \mathrm{mg} \mathrm{L}^{-1}$.

Na Figura 18 encontra-se apresentado o gráfico de demanda de $\mathrm{ClO}_{2} \mathrm{em}$ função da dosagem de $\mathrm{ClO}_{2}$ utilizadas nos ensaios, com dados extraídos da Tabela 8 .

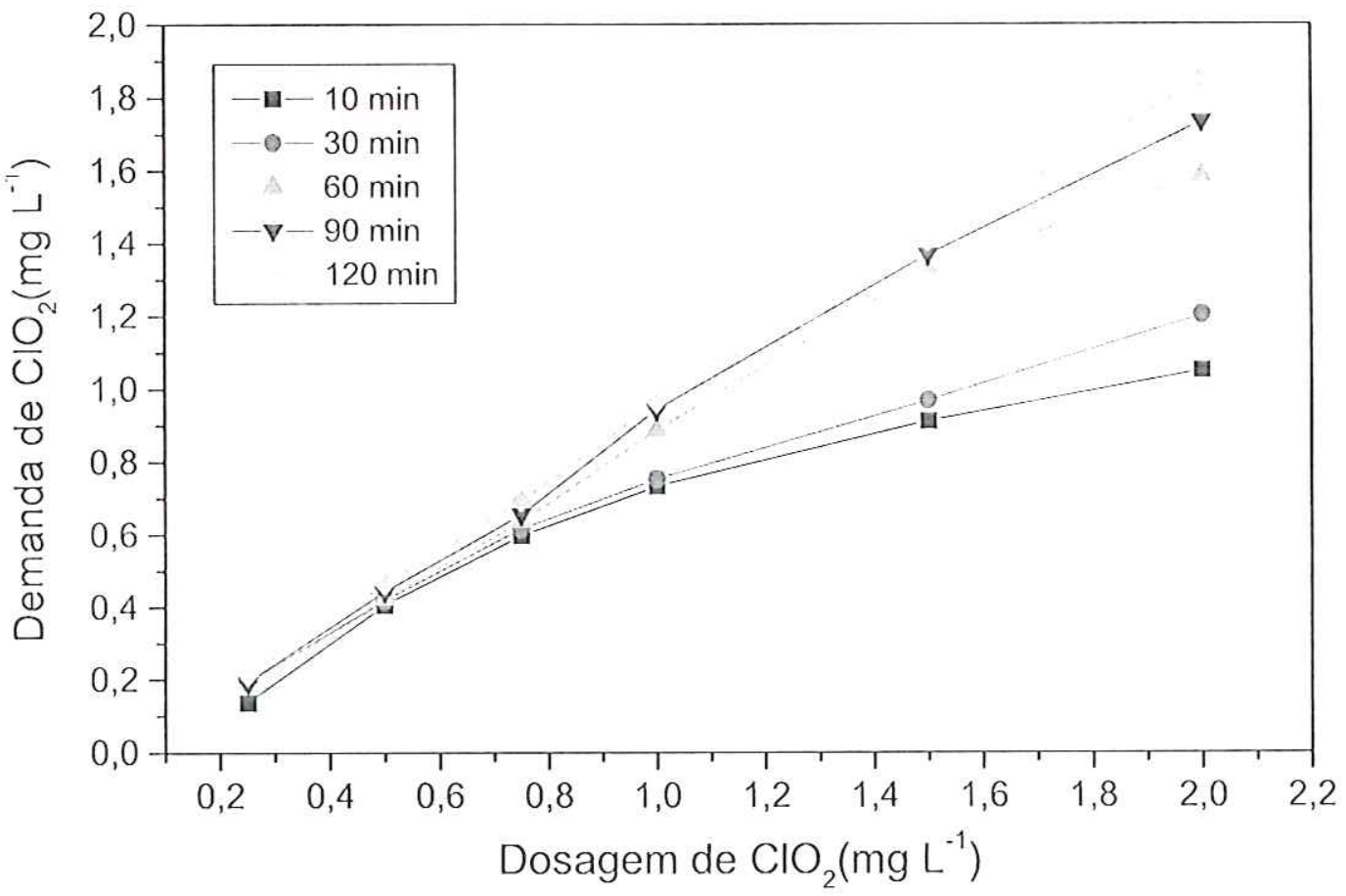

Figura 18 - Demanda de $\mathrm{ClO}_{2}$ em função da dosagem do oxidante, água preparada com a fração de tamanho molecular entre $0-45 \mu \mathrm{m}$. 
Capitulo 2

61

A demanda do oxidante é definida como a quantidade consumida deste oxidante pelas substâncias, que devem se oxidadas, num determinado espaço de tempo.

Analisando-se a Figura 18, observa-se que o consumo do oxidante $\mathrm{ClO}_{2}$ aumenta com o aumento do tempo da reação, principalmente para concentrações superiores a $1,0 \mathrm{mg} \mathrm{L}^{-1}$, e para concentrações menores do que $1,0 \mathrm{mg} \mathrm{L}^{-1}$, existe a tendência do consumo de $\mathrm{ClO}_{2}$, começar a permanecer constante após as duas horas de ensaio. Nas Tabelas 9 e 10 encontram-se os resultados dos ensaios de oxidação com o oxidante dióxido de cloro, cujas águas foram preparadas respectivamente com SH de tamanho molecular maior do que $100 \mathrm{KDa}$ e SH de tamanho molecular no intervalo entre 30-100 KDa.

Tabela 9 - Ensaios de demanda realizados com dosagens do oxidante dióxido de cloro de 0,25 a $2,0 \mathrm{mg} \mathrm{L}^{-1}$, água preparada com substâncias húmicas de tamanho molecular entre 30-100 KDa.

\begin{tabular}{|c|c|c|c|c|c|c|}
\hline \multirow{2}{*}{$\begin{array}{l}\text { Condições iniciais do ensaio: } \\
\text { Temperatura: } 23^{\circ} \mathrm{C} \\
\text { pH inicial: } 6,5 \\
\quad \text { Cor da água: } 105 \text { uH } \\
\text { Rotação: } 45 \mathrm{rpm}\end{array}$} & Dosé & gens d & $\begin{array}{l}\text { oxida } \\
\text { o ensa }\end{array}$ & te dióx & ido utili & zadas \\
\hline & 0,25 & 0,5 & 0,75 & 1,0 & 1,5 & 2,0 \\
\hline $\mathrm{pH}$ final após $120 \mathrm{~min}$ & 6,83 & 6,8 & 6,74 & 6,70 & 6,49 & 6,45 \\
\hline Cor final após $120 \mathrm{~min}$ & 108 & 106 & 100 & 96 & 92 & 66 \\
\hline Residual de $\mathrm{ClO}_{2}\left(\mathrm{mg} \mathrm{L}^{-1}\right) 10 \mathrm{~min}$ & 0,057 & 0,076 & 0,133 & 0,095 & 0,171 & 0,285 \\
\hline Demanda de $\mathrm{ClO}_{2}$ em $10 \mathrm{mim}$ & 0,193 & 0,424 & 0,617 & 0,905 & 1,329 & 1,715 \\
\hline Residual de $\mathrm{ClO}_{2}\left(\mathrm{mg} \cdot \mathrm{L}^{-1}\right) 30 \mathrm{~min}$ & 0,057 & 0,038 & 0,095 & 0,095 & 0,114 & 0,114 \\
\hline Demanda de $\mathrm{ClO}_{2}$ em $30 \mathrm{mim}$ & 0,193 & 0,462 & 0,655 & 0,905 & 1,386 & 1,886 \\
\hline Residual de $\mathrm{ClO}_{2}\left(\mathrm{mg} \cdot \mathrm{L}^{-1}\right) 60 \mathrm{~min}$ & 0,038 & 0,076 & 0,076 & 0,095 & 0,095 & 0,095 \\
\hline Demanda de $\mathrm{ClO}_{2}$ em $60 \mathrm{mim}$ & 0,212 & 0,424 & 0,674 & 0,905 & 1,405 & 1,905 \\
\hline Residual de $\mathrm{ClO}_{2}\left(\mathrm{mg}^{-\mathrm{L}^{-1}}\right) 90 \mathrm{~min}$ & 0,076 & 0,057 & 0,076 & 0,076 & 0,095 & 0,076 \\
\hline Demanda de $\mathrm{ClO}_{2}$ em $90 \mathrm{mim}$ & 0,174 & 0,433 & 0,674 & 0,924 & 1,405 & 1,924 \\
\hline Residual de $\mathrm{ClO}_{2}\left(\mathrm{mg} \cdot \mathrm{L}^{-1}\right) 120 \mathrm{~min}$ & 0,038 & 0,057 & 0,095 & 0,057 & 0,076 & 0,095 \\
\hline Demanda de $\mathrm{ClO}_{2}$ em $120 \mathrm{mim}$ & 0,212 & 0,443 & 0,655 & 0,943 & 1,424 & 1,905 \\
\hline
\end{tabular}


Tabela 10 - Ensaios de demanda realizados com dosagens do oxidante dióxido de cloro de 0,25 a 2,0 mg. $\mathrm{L}^{-1}$, água preparada com substâncias húmicas de tamanho molecular maior do que $100 \mathrm{KDa}$.

\begin{tabular}{|c|c|c|c|c|c|c|}
\hline \multirow{2}{*}{$\begin{array}{l}\text { Condições iniciais do ensaio } \\
\text { Cor da água: } 100 \\
\text { pH inicial da água de estudo: } 6,69 \\
\text { Temperatura; } 23^{\circ} \mathrm{C} \\
\text { Rotação: } 45 \text { rpm }\end{array}$} & dosag & ns do & $\begin{array}{l}\text { xidant } \\
\text { ensaio }\end{array}$ & dióxid & o utiliz & das no \\
\hline & 0,25 & 0,5 & 0,75 & 1,0 & 1,5 & 2,0 \\
\hline $\mathrm{pH}$ final após $120 \mathrm{~min}$ & 6,85 & 6,83 & 6,80 & 6,79 & 6,77 & 6,66 \\
\hline cor final após $120 \mathrm{~min}$ & 94 & 93 & 90 & 88 & 84 & 78 \\
\hline residual de $\mathrm{ClO}_{2}\left(\mathrm{mg} \mathrm{L}^{-1}\right) 10 \mathrm{~min}$ & 0,114 & 0,114 & 0,076 & 0,076 & 0,171 & 0,475 \\
\hline demanda de $\mathrm{ClO}_{2}$ em $10 \mathrm{mim}$ & 0,136 & 0,386 & 0,674 & 0,924 & 1,329 & 1,525 \\
\hline residual de $\mathrm{ClO}_{2}\left(\mathrm{mg} \mathrm{L}^{-1}\right) 30 \mathrm{~min}$ & 0,095 & 0,095 & 0.057 & 0,057 & 0,114 & 0,361 \\
\hline demanda de $\mathrm{ClO}_{2}$ em $30 \mathrm{mim}$ & 0,155 & 0,405 & 0,693 & 0,943 & 1,386 & 639 \\
\hline residual de $\mathrm{ClO}_{2}\left(\mathrm{mg} \mathrm{L}^{-1}\right) 60 \mathrm{~min}$ & 0,057 & 0,057 & 0,057 & 0,057 & 0,076 & 0,19 \\
\hline demanda de $\mathrm{ClO}_{2}$ em $60 \mathrm{mim}$ & 0,193 & 0,443 & 0,693 & 0,943 & 1,424 & 1,81 \\
\hline residual de $\mathrm{ClO}_{2}\left(\mathrm{mg} \mathrm{L}^{-1}\right) 90 \mathrm{~min}$ & 0,076 & 0,114 & 0,095 & 0,057 & 0,057 & 0,152 \\
\hline demanda de $\mathrm{ClO}_{2}$ em $90 \mathrm{mim}$ & 0,174 & 0,386 & 0,655 & 0,943 & 1,443 & 1,848 \\
\hline residual de $\mathrm{ClO}_{2}\left(\mathrm{mg} \mathrm{L}^{-1}\right) 120 \mathrm{~min}$ & 0,038 & 0,057 & 0,095 & 0,057 & 0,076 & 0,095 \\
\hline demanda de $\mathrm{ClO}_{2}$ em $120 \mathrm{mim}$ & 0,212 & 0,443 & 0,655 & 0,943 & 1,424 & 1,905 \\
\hline
\end{tabular}

Analisando-se as Tabelas 9 e 10, verificou-se um comportamento semelhante aos ensaios realizados com a água de estudo preparada com as frações das substâncias húmicas de tamanho molecular entre 0-0,45 بm, ou seja com relação a cor, pH, diminuição da concentração de $\mathrm{ClO}_{2}$ em função do tempo de reação.

As concentrações típicas de dióxido de cloro normalmente utilizadas nas estações de tratamento variam 0,07 a $2,0 \mathrm{mg} \mathrm{L}^{-1}$. Porém sabe-se que quanto maior a dosagem de dióxido de cloro utilizada na oxidação da água, maiores serão as concentrações de clorito e de clorato formadas, sendo estas substâncias cancerigenas, e cujas concentrações máximas permitidas segundo a (USEPA, 1998), são respectivamente de 0,24 e $0,20 \mathrm{mg} \mathrm{L}^{-1}$. Analisando-se os residuais de $\mathrm{ClO}_{2}$ após as duas horas de ensaio, apresentados nas Tabelas 8, 9 e 
10, quando utilizou-se uma dosagem de $1,0 \mathrm{mg} \mathrm{L}^{-1}$, observa-se um pequeno residual, o que vem a minimizar a formação de clorito e clorato. A dosagem de cloro a ser utilizada nos ensaios de pré-oxidação para determinar os suprodutos clorados, será de 1,0 $\mathrm{mg} \mathrm{L}^{-1}$, com base na recomendação da (USEPA, 1998), a qual recomenda uma dosagem máxima de $1,0 \mathrm{mg} \mathrm{L}^{-1}$. Segundo estudos realizados por Demers (USEPA, 1998), para concentrações maiores que $1,0 \mathrm{mg} \mathrm{L}^{-1}$, a concentração de clorado ficou acima do permitido.

2.4.2 - Ensaios para determinar a concentração de cloro "demanda de cloro" a serem utilizadas nos ensaios de formação dos subprodutos clorados.

Na Tabela 11 encontra-se apresentados os resultados dos ensaios de oxidação com o pré-oxidante cloro, de uma água preparada com SH de tamanho molecular menor que $0,45 \mu \mathrm{m}$.

Tabela 11 - ensaios de pré-oxidação com o cloro, cuja água foi preparada com fraçoes de SH de tamanho molecular de $0-0,45 \mu \mathrm{m}$.

\begin{tabular}{|c|c|c|c|c|c|c|c|c|}
\hline \multirow{2}{*}{$\begin{array}{l}\text { Condições iniciais do ensaio: } \\
\quad \text { Cor da água de estudo: } 104 \text { uH } \\
\text { pH: } 6,4 \\
\text { Temperatura: } 23^{\circ} \mathrm{C} \\
\text { Rotação: } 45 \text { rpm }\end{array}$} & \multicolumn{8}{|c|}{$\begin{array}{l}\text { Dosagens do oxidante cloro utilizadas no } \\
\text { ensaio }\left(\mathrm{mg} \mathrm{L}^{-1}\right)\end{array}$} \\
\hline & 1,0 & 2,0 & 4,0 & 6,0 & 7,0 & 8,0 & 10,0 & 12,0 \\
\hline $\mathrm{pH}$ final após $120 \mathrm{~min}$ & 6,8 & 6,47 & 6,7 & 6,75 & 6,77 & 6,75 & 6,74 & 6,66 \\
\hline cor final após $120 \mathrm{~min}(\mathrm{uH} \mathrm{PtCO})$ & 84 & 75 & 84 & 80 & 78 & 85 & 86 & 88 \\
\hline residual de $\mathrm{Cl}_{2}\left(\mathrm{mg} \mathrm{L}^{-1}\right) 10 \mathrm{~min}$ & 0,12 & 0,53 & 1,46 & 2,20 & 2,28 & 2,96 & 2,90 & 3,98 \\
\hline demanda de $\mathrm{Cl}_{2}$ em $10 \mathrm{mim}$ & 0,88 & 1,47 & 2,54 & 3,8 & 4,72 & 5,04 & 7,1 & 8,02 \\
\hline residual de $\mathrm{Cl}_{2}\left(\mathrm{mg} \mathrm{L}^{-1}\right) 30 \mathrm{~min}$ & 0,06 & 0,5 & 1,21 & 2,12 & 2,08 & 3,14 & 3,16 & 4,20 \\
\hline demanda de $\mathrm{Cl}_{2}$ em $30 \mathrm{mim}$ & 0,94 & 1,50 & 2,79 & 3,88 & 4,92 & 4,86 & 6,40 & 7,80 \\
\hline residual de $\mathrm{Cl}_{2}\left(\mathrm{mg} \mathrm{L}^{-1}\right) 60 \mathrm{~min}$ & 0,03 & 0,35 & 1,14 & 2,08 & 1,96 & 3,26 & 2,74 & 4,05 \\
\hline demanda de $\mathrm{Cl}_{2}$ em $60 \mathrm{mim}$ & 0,97 & 1,65 & 2,86 & 3,92 & 5,04 & 4,74 & 7,26 & 7,95 \\
\hline
\end{tabular}


Tabela 11 - ensaios de pré-oxidação com o cloro, cuja água foi preparada com SH filtrada em filtro $0,45 \mu \mathrm{m}$.

\begin{tabular}{|c|c|c|c|c|c|c|c|c|}
\hline \multirow{2}{*}{$\begin{array}{l}\text { Condições iniciais do ensaio: } \\
\quad \text { Cor da água de estudo: } 104 \mathrm{uH} \\
\text { pH: } 6,4 \\
\text { Temperatura: } 23^{\circ} \mathrm{C} \\
\text { Rotação: } 45 \mathrm{rpm}\end{array}$} & \multicolumn{8}{|c|}{$\begin{array}{c}\text { Dosagensdo oxidante cloro utilizadas no } \\
\text { ensaio }\left(\mathrm{mg} \mathrm{L}^{-1}\right)\end{array}$} \\
\hline & 1,0 & 2,0 & 4,0 & 6,0 & 7,0 & 8,0 & 10,0 & 12,0 \\
\hline residual de $\mathrm{Cl}_{2}\left(\mathrm{mg} \mathrm{L}^{-1}\right) 90 \mathrm{~min}$ & 0,03 & 0,35 & 0,96 & 1,91 & 1,92 & 3,00 & 3,08 & 4,45 \\
\hline demanda de $\mathrm{Cl}_{2}$ em $90 \mathrm{mim}$ & 0,97 & 0,65 & 3,04 & 4,09 & 5,08 & 7,00 & 6,92 & 7,55 \\
\hline residual de $\mathrm{Cl}_{2}\left(\mathrm{mg} \mathrm{L}^{-1}\right) 120 \mathrm{~min}$ & 0,03 & 0,29 & 0,85 & 1,93 & 1,88 & 3,06 & 2,8 & 3,95 \\
\hline demanda de $\mathrm{Cl}_{2} \mathrm{e}$ & 0,97 & 1,71 & 3,15 & 4,07 & 5,12 & 4,94 & 7,2 & 8,05 \\
\hline
\end{tabular}

Analisando-se os dados apresentados na Tabela 11 observa-se, que a adição do oxidante cloro à água de estudo, promove uma diminuição considerável na cor da água, chegando a uma porcentagem de redução de $31,5 \%$, quando utilizou-se uma concentração de $2,0 \mathrm{mg} \mathrm{L}^{-1}$ de cloro livre. A diminuição da cor deve-se a oxidação de estruturas presentes nas substâncias húmicas, tais como, grupo aromáticos, carboxílicos, quinonas, dentre outros, as quais são responsáveis pela cor da água Pomes et al. (1999).

Analisando-se os valores de $\mathrm{pH}$ apresentados na Tabela 11, nota-se que ocorre um pequeno aumento do $\mathrm{pH}$ em relação ao inicial da água de estudo, ou seja, sem a adição do oxidante cloro. Este aumento ocorre provavelmente devido aos subprodutos formados durante a reação das $\mathrm{SH}$ com o cloro (DI BERNARDO, 1995). Caso a água estivesse insenta de impurezas, iria ocorrer o contrário, uma diminuição do pH, pois ao adicionar-se um derivado clorado a água, este é hidrolisado, e ocorre a formação do ácido hipocloroso, um ácido fraco, cuja constante de dissociação, pKa, a $30^{\circ} \mathrm{C}$ é de $3,10^{-8}$. O extensão da ionização do ácido hipocloroso em $\mathrm{H}_{3} \mathrm{O}^{+}$e $\mathrm{ClO}^{-}$depende do $\mathrm{pH}$ do meio reacional, na condição de estudo $\mathrm{pH}$ 6,6, ocorre a predominância dos ions $\mathrm{H}_{3} \mathrm{O}^{+}$e $\mathrm{ClO}^{-}$ (MACÊDO, 2001).

Na Figura 19 encontra-se apresentado o gráfico referente ao residual de cloro versus dosagem de cloro, com dados extraídos da Tabela 11 e na Figura 20 
o gráfico de demanda de cloro em função da dosagem de cloro, também com dados extraídos da Tabela 11.

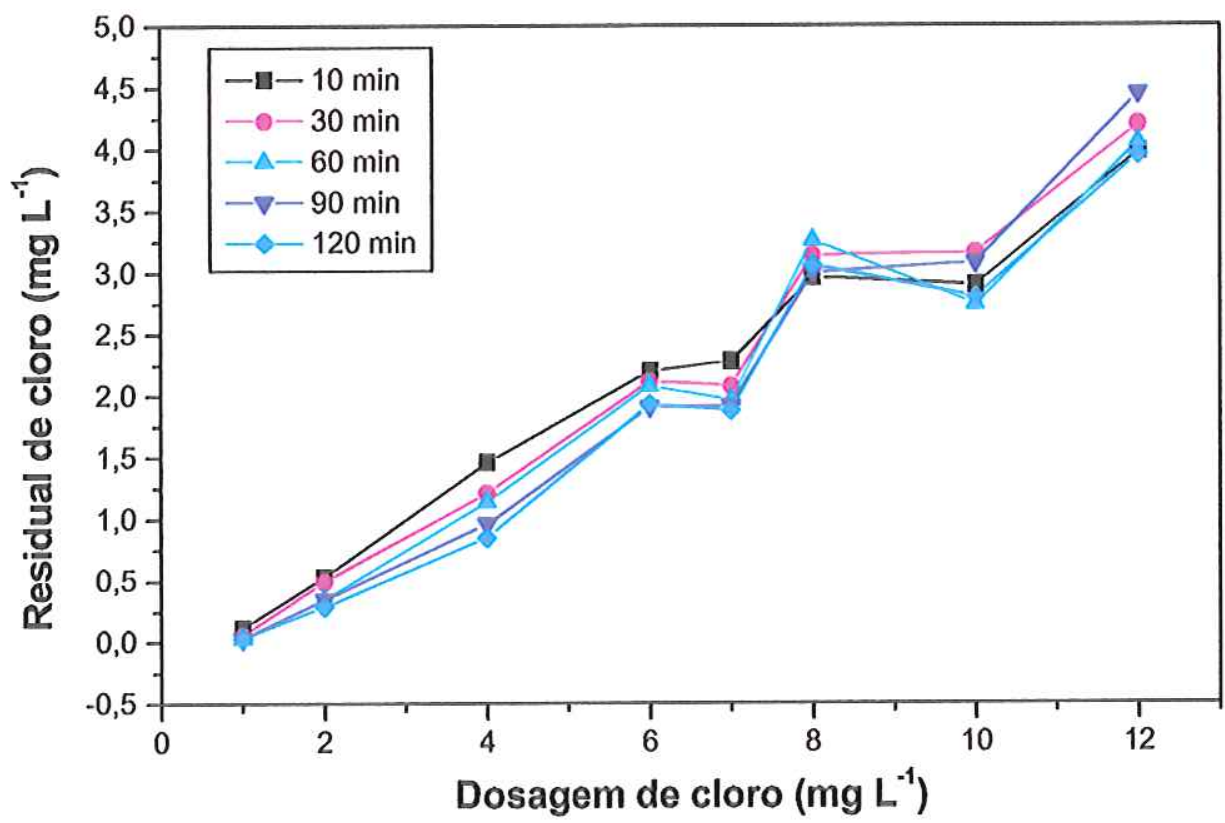

Figura 19 - Residual de cloro versus dosagem de cloro

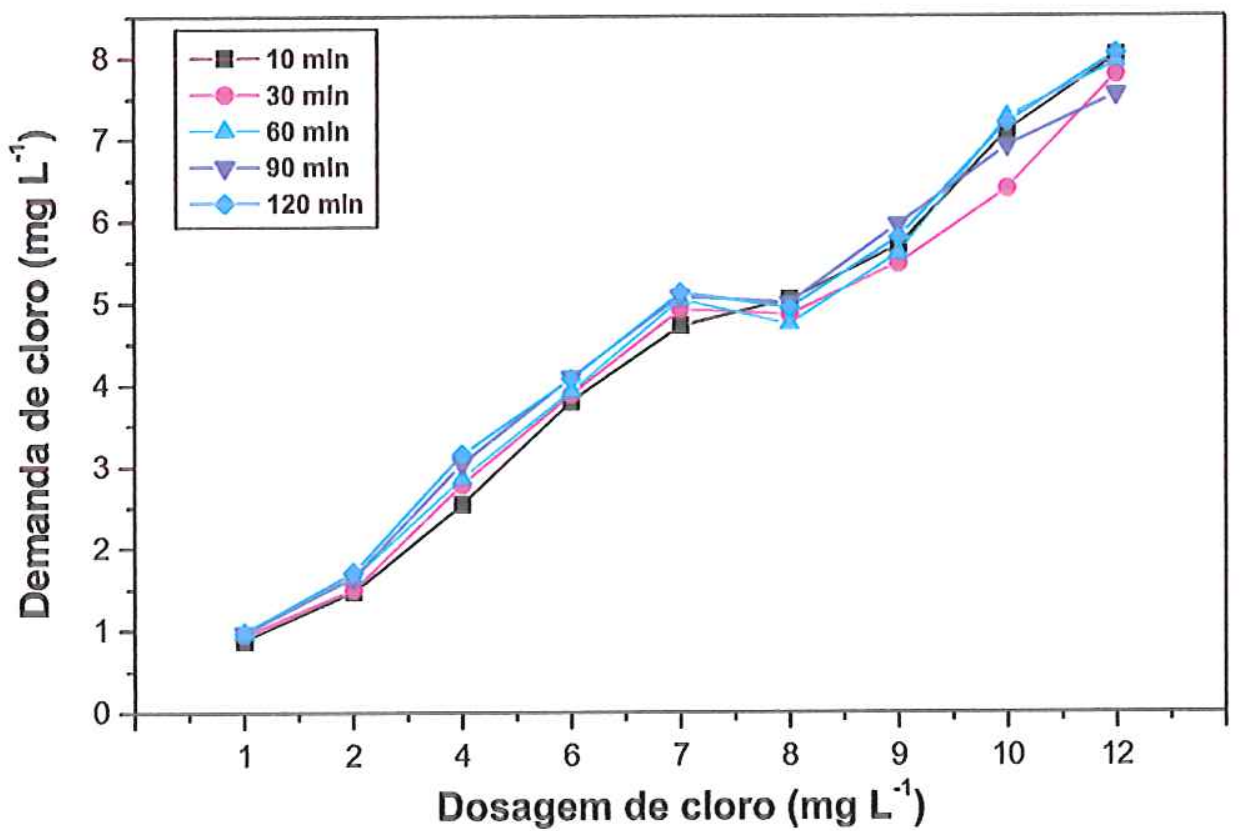

Figura 20 - Demanda de cloro versus dosagem aplicada do oxidante na água preparada com SH de tamanho molecular $0,45 \mu \mathrm{m}$. 
Analisando-se as Figuras 19 e 20, observa-se que ocorre uma diminuição do residual de cloro e um aumento da demanda de cloro, com o aumento do tempo da reação, tempo de contato. A diminuição do residual de cloro e aumento da demanda, ocorre principalmente durante os dez primeiros minutos da reação, devido ao maior consumo do oxidante cloro para oxidar as substâncias húmicas. Após os dez primeiros minutos da reação, continua a ocorrer um aumento da demanda de cloro e diminuição residual, porém a uma taxa menor. Após as duas horas de ensaio, nota-se um baixo residual de cloro no intervalo de 1 a $2 \mathrm{mg} \mathrm{L}^{-1}$, porém para dosagens acima de $8,0 \mathrm{mg} \mathrm{L}^{-1}$, tem-se a presença de uma alta concentração do residual de cloro, como pode ser observado pelos dados apresentados na Tabela 11. Para a dosagem de $7,0 \mathrm{mg} \mathrm{L}^{-1}$ o residual e demanda de cloro tende a ficar constante nos intervalos de tempos estudados. Nas Tabelas 12 e 13 encontram-se os resultados dos ensaios de pré-oxidação com o cloro. Uma água de estudo foi preparada empregando-se frações das SH de tamanho molecular maior do que $100 \mathrm{KDa}$ e outra no intervalo de 30-100 KDa. 
Capítulo 2

Tabela 12 - ensaios de pré-oxidação com o cloro, cuja água foi preparada com frações das SH de tamanho molecular maior do que $100 \mathrm{KDa}$.

\begin{tabular}{|c|c|c|c|c|c|c|c|c|}
\hline \multirow{2}{*}{$\begin{array}{l}\text { Condições iniciais: } \\
\text { Cor da água: } 105 \mathrm{uH} \\
\text { pH da água de estudo: } 6,5 \\
\text { Temperatura : } 23^{0} \mathrm{C}\end{array}$} & \multicolumn{8}{|c|}{$\begin{array}{c}\text { Dosagens do oxidante cloro utilizadas no } \\
\text { ensaio }\left(\mathrm{mg} \mathrm{L}^{-1}\right)\end{array}$} \\
\hline & 1,0 & 2,0 & 4,0 & 6,0 & 7,0 & 8,0 & 10,0 & 12,0 \\
\hline 120 । & 6,71 & 6,75 & 6,78 & 6,63 & 6,63 & 6,62 & 6,8 & 6,75 \\
\hline cor final após $120 \mathrm{~m}$ & 97 & 95 & 87 & 89 & 90 & 85 & 87 & 81 \\
\hline residual de $\mathrm{Cl}_{2}$ ( & 0,30 & 0,76 & 1,89 & 2,64 & 2,50 & 3,30 & 3,06 & 3,78 \\
\hline demanda & 0,70 & 1,24 & 2,10 & 3,36 & 4,50 & 4,70 & 6,94 & 8,22 \\
\hline residual de $\mathrm{Cl}_{2}$ ( & 0,24 & 0,62 & 1,23 & 2,50 & 2,20 & 3,52 & 3,42 & 3,72 \\
\hline demanda de $\mathrm{Cl}_{2}$ em $30 \mathrm{mim}$ & 0,76 & 1,38 & 2,15 & 3,5 & 4,80 & 4,48 & 6,58 & 8,28 \\
\hline residual de & 0,15 & 0,44 & 1,70 & 2,38 & 2,10 & 3,24 & 3,10 & 3,70 \\
\hline demand & 0,85 & 1,56 & 2,30 & 3,62 & 4,90 & 4,76 & 6,90 & 8,30 \\
\hline residual de $\mathrm{Cl}_{2}\left(\mathrm{mg} \mathrm{L}^{-1}\right) 90 \mathrm{~min}$ & 0,08 & 0,33 & 1,46 & 2,10 & 2,09 & 3,22 & 3,12 & 3,68 \\
\hline demanda de $\mathrm{Cl}_{2}$ em $90 \mathrm{mim}$ & 0,92 & 1,67 & 2,56 & 3,90 & 4,91 & 4,78 & 6,88 & 8,32 \\
\hline residual de $\mathrm{Cl}_{2}\left(\mathrm{mg} \mathrm{L}^{-1}\right) 120 \mathrm{~min}$ & 0,05 & 0,25 & 1,35 & 1,88 & 2,00 & 2,76 & 3,13 & 3,62 \\
\hline demanda de $\mathrm{Cl}_{2}$ em 120 & 0,95 & 1,75 & 2,65 & 4,12 & 5,00 & 5,24 & 6,68 & 8,38 \\
\hline
\end{tabular}

Tabela 13- ensaios de pré-oxidação com o cloro, cuja água foi preparada com SH de tamanho molecular no intervalo de 30-100 KDa.

\begin{tabular}{|c|c|c|c|c|c|c|c|c|}
\hline \multirow{2}{*}{$\begin{array}{l}\text { Condições: } \\
\text { Cor da água: } 104 \mathrm{uH} \\
\text { pH: } 6,4 \\
\text { Temperatura: } 23^{\circ} \mathrm{C}\end{array}$} & \multicolumn{8}{|c|}{$\begin{array}{c}\text { Dosagens do oxidante cloro utilizadas no } \\
\text { ensaio }\left(\mathrm{mg} \mathrm{L}^{-1}\right)\end{array}$} \\
\hline & 1,0 & 2,0 & 4,0 & 6,0 & 7,0 & 8,0 & 10,0 & 12,0 \\
\hline $\mathrm{pH}$ final após $120 \mathrm{~min}$ & 6,8 & 6,9 & 6,9 & 6,7 & 6,7 & 6,6 & 6,6 & 6,5 \\
\hline cor final após $120 \mathrm{~min}(\mathrm{uH} \mathrm{PtCO})$ & 101 & 94 & 83 & 81 & 80 & 77 & 77 & 77 \\
\hline residual de $\mathrm{Cl}_{2}\left(\mathrm{mg} \mathrm{L}^{-1}\right) 10 \mathrm{~min}$ & 0,04 & 0,22 & 0,94 & 1,63 & 2,0 & 2,1 & 2,7 & 3,5 \\
\hline demanda de $\mathrm{Cl}_{2}$ em $10 \mathrm{mim}$ & 0,96 & 1,78 & 3,06 & 4,37 & 5,0 & 5,9 & 7,3 & 8,5 \\
\hline residual de $\mathrm{Cl}_{2}\left(\mathrm{mg} \mathrm{L}^{-1}\right) 30 \mathrm{~min}$ & 0,03 & 0,16 & 0,83 & 1,60 & 2,0 & 2,0 & 2,5 & 3,0 \\
\hline demanda de $\mathrm{Cl}_{2}$ em $30 \mathrm{mim}$ & 0,97 & 1,84 & 3,17 & 4,40 & 5,0 & 6,0 & 7,5 & 9,0 \\
\hline residual de $\mathrm{Cl}_{2}\left(\mathrm{mg} \mathrm{L}^{-1}\right) 60 \mathrm{~min}$ & 0,02 & 0,06 & 0,42 & 1,48 & 1,98 & 1,98 & 2,10 & 2,6 \\
\hline
\end{tabular}


Tabela 13- ensaios de pré-oxidação com o cloro, cuja água foi preparada com SH de tamanho molecular no intervalo de 30-100 KDa.

\begin{tabular}{|l|r|c|c|c|c|c|c|c|}
\hline $\begin{array}{l}\text { Condições: } \\
\begin{array}{l}\text { Cor da água: } 104 \mathrm{uH} \\
\text { pH: } 6,4\end{array} \\
\text { Temperatura: } 23^{0} \mathrm{C}\end{array}$ & \multicolumn{7}{|c|}{ Dosagens do oxidante cloro utilizadas no } \\
\cline { 2 - 10 } & 1,0 & 2,0 & 4,0 & 6,0 & 7,0 & 8,0 & 10,0 & 12,0 \\
\hline demanda de $\mathrm{Cl}_{2}$ em $60 \mathrm{mim}$ & 0,98 & 1,94 & 3,58 & 4,52 & 5,02 & 6,02 & 7,9 & 9,4 \\
\hline residual de $\mathrm{Cl}_{2}\left(\mathrm{mg} \mathrm{L}^{-1}\right) \mathbf{9 0} \mathrm{min}$ & 0,02 & 0,03 & 0,51 & 1,39 & 1,75 & 2,0 & 2,2 & 2,5 \\
\hline demanda de $\mathrm{Cl}_{2}$ em $90 \mathrm{mim}$ & 0,98 & 1,97 & 3,49 & 4,61 & 5,25 & 6,0 & 7,8 & 9,5 \\
\hline residual de $\mathrm{Cl}_{2}\left(\mathrm{mg} \mathrm{L}^{-1}\right) 120 \mathrm{~min}$ & 0,01 & 0,02 & 0,42 & 1,23 & 1,73 & 1,9 & 1,8 & 2,48 \\
\hline demanda de $\mathrm{Cl}_{2}$ em 120 mim & 0,99 & 1,98 & 3,58 & 4,77 & 5,27 & 6,1 & 8,2 & 9,52 \\
\hline
\end{tabular}

Analisando-se as Tabelas 11, 12 e 13, definiu-se a demanda de cloro como sendo de 7,0 $\mathrm{mg} \mathrm{L}^{-1}$, visto que os residuais após os 120 minutos de ensaios, ficaram no intervalo de 1,73 a $2,0 \mathrm{mg} \mathrm{L}^{-1}$ e praticamente constantes no intervalo de estudo. E segundo a portaria $N^{0} 518$ de março de 2004, recomenda-se que o teor máximo de cloro residual, em qualquer ponto do sistema de abastecimento seja no. máximo de $2,0 \mathrm{mg} \mathrm{L}^{-1}$.

\section{5 - CONCLUSÕES}

As dosagens de cloro e díoxido de cloro a serem utilizadas nos enśaios de oxidação da água de estudo para determinação dos subprodutos clorados, foram determinadas baseando-se nas concentrações dos residuais. A dosagem de cloro determinada foi de $7,0 \mathrm{mg} \mathrm{L}^{-1}$, visto que a portaria $\mathrm{N}^{0} 518$ de março de 2004, recomenda que o teor máximo de cloro residual, em qualquer ponto do sistema de abastecimento seja no máximo de $2,0 \mathrm{mg} \mathrm{L}^{-1}$. Já a dosagem de dióxido de cloro foi de $1,0 \mathrm{mg} \mathrm{L}^{-1}$, a qual foi determinada com base na recomendação da (USEPA, 1998), a qual recomenda uma dosagem máxima de $1,0 \mathrm{mg} \mathrm{L}^{-1}$. Sabe-se, que para dosagens maiores de dióxido de cloro, pode ocorrer uma maior formação de clorito e clorato, que são prejudiciais à saúde.

Com relação à cor da água, observou-se que o oxidante dióxido de cloro, possui maior ação oxidante, sobre a matéria orgânica, do que o oxidante cloro. 


\section{6 - CONSIDERAÇÕES A RESPEITO DO CAPÍTULO 2}

No capítulo 2 foram determinadas as dosagens de cloro e dióxido de cloro a serem utilizadas, nos ensaios de oxidação da água contendo frações das SH. No capítulo 4 são determinados os subprodutos da oxidação formados, quando foram utilizadas dosagens de cloro e dióxido respectivamente de 7,0 e 1,0 $\mathrm{mg} \mathrm{L}^{-1}$. $\mathrm{Na}$ quantificação dos subprodutos formados durante a oxidação da água contendo $\mathrm{SH}$, foi utilizada a cromatografia gasosa com detector de captura de elétrons, cujo método foi desenvolvido e validado no capítulo 3 . 
CAPITULO - 3

Validação do método analítico utilizado para a determinação dos subprodutos da oxidação.

\section{3 - INTRODUÇÃO}

O desenvolvimento de um método analítico, adaptação ou implementação de método conhecido, envolve um processo de avaliação que estime sua eficiência na rotina do laboratório. Esse processo costuma ser chamado de validação (LEITE, 2002; RIBANI, 2004). A validação é um processo que fornece uma evidência documentada de que o método é confiável ao que se aplica Cass e Degani (2001). Ele consiste em uma série de procedimentos que visam assegurar credibilidade às medidas obtidas.

Os erros incidentes, humanos e de materiais, mesmo em uma simples comparação de propriedades em um sistema, torna dificil saber se um resultado é válido ou não. Por outro lado, não há um método de validação que seja absolutamente seguro,100\% de confiabilidade. Assim, definir o melhor método de validação passa a ser um critério pessoal e sua aceitação gera conflitos. Como não há metodologia e modelos de validação prontos, o interessado em validar o método por ele empregado deve procurar seguir recomendações adequando às suas necessidades Cass e Degani (2001). Deve-se ter em mente que sem validação, tem-se apenas um número e não um resultado.

A validação em análise química, parte do pressuposto de que em determinado momento do processo os equipamentos foram calibrados e aferidos em termos de qualidade da instrumentação bem como da qualidade de sua manutenção (POLITO, 2002).

Deste modo, validar um resultado é ter um equipamento e uma sequência analitica aceita como correta. Para tanto, devem ser estabelecidos critérios de exigência por meio de reflexão pessoal e da aplicação correta dos conceitos estatísticos para se definir o grau de exigência para a validação do 
resultado analítico que deve ter qualidade analítica, em outras palavras os resultados devem ser confiáveis.

Assim, deve-se ter disponivel um sistema de confiabilidade analítica constando de gráficos, procedimentos padrão, normas, rotinas específicas, formulários como garantias técnicas (POLITO, 2002). Em decorrência desses fatores é que surge a importância em se caracterizar resultados instrumentais em processos de validação.

A literatura dispõe de trabalhos que relatam a validação de métodos analiticos Brito et al. (2003) e define os critérios que devem ser seguidos durante seu desenvolvimento.

\section{1 - Critérios de validação}

Normalmente, investigam-se a especificidade e seletividade, a curva analitica, o intervalo de trabalho, a linearidade, a precisão, a exatidão, a recuperação, a sensibilidade, os limites de deteç̧ão e a quantificação (LEITE, 2002; BRITO, 2003). A seguir são definidos e discutidos os parâmetros que são utilizados para a validação do método.

\subsection{1 - Especificidade e seletividade}

A seletividade é a habilidade de um método separar, do composto de interesse, componentes da amostra que serão visíveis no detector Cass e Degani (2001), asseguram que o sinal medido não é influenciado por substâncias interferentes. A seletividade é determinada analisando-se diversas amostras da matriz ( $n \geq 6$ ), para que se investigue a possivel presença de compostos que interfiram ou se sobreponham ao sinal do composto de interesse. Já a especificidade é definida como a capacidade do método em detectar o analito de interesse na presença de outros componentes (ICH, 1997). 
O processo para demonstrar a especificidade do método depende do seu objetivo. Como substâncias diferentes podem apresentar respostas similares em dadas condições, deve-se proceder à análise seguida por outras técnicas comprobatórias. Outra forma de avaliar a especificidade envolve a comparação com padrão externo Bressolle et al. (1996).

\subsection{2 - Limite de deteç̧ão}

O termo limite de detecção é um dos parâmetros úteis para se escolher um determinado método analítico. Ele está associado a sinais analíticos instrumentais, principalmente, sendo sua conceituação bastante conflitante. Considera-se, inicialmente, a incorporação de duas variáveis: a magnitude do sinal analítico e a linha de base com o respectivo ruido para dar a indicação de uma concentração de um elemento possível de ser medido. O limite de detecção é definido de várias maneiras muitas delas contraditórias (POLITO, 2002; RIBANI, 2004). Segundo (GREEN, 1996), o limite de detecção é a menor quantidade do analito detectável, nas condições experimentais estabelecidas pela metodologia, não necessariamente quantificada como valor exato. Corresponde à concentração produtora de sinal medido de três vezes o nivel do ruído médio medido. Outra definição estabelece o limite de detecção como sendo a concentração referente a um dado sinal analítico, seja ele de corrente de pico, voltametria, absorbância, em métodos espectrofométricos, ou qualquer outro sinal analitico corresponde $A$ duas ou três vezes (IUPAC) vezes a magnitude da linha de base com ruido. A linha de base com ruido pode ser analisada, estatisticamente, fazendo-se pelo menos vinte medidas de um branco para se obter a linha de base do sinal observado, determinando a estimativa do desvio padrão destas medidas. A eq.(13) exemplifica o exposto anteriormente.

$$
L D=X_{b}+K S_{b}
$$


onde:

$X_{b}=$ média de $n$ medidas do branco $(n \geq 20)$

$K=3$

$\mathrm{S}_{\mathrm{b}}=$ estimativa do desvio padrão das medidas do branco

O limite de detecção pode ser determinado mediante o sinal e ruído. O desvio-padrão da resposta e do coeficiente angular é calculado estatisticamente.

O sinal e ruído pode ser aplicado somente para processos analíticos que exibem linha de base. A determinação da razão do sinal/ruido é realizada por meio de comparação dos sinais medidos da amostra com baixas concentrações conhecidas do analito com as do branco, estabelecendo a minima concentração na qual o analito pode ser detectado. A razão sinal/ruido deve ser três vezes o desvio padrão de um branco como demonstrado na eq.(14) (GREEN, 1996).

$$
\mathrm{LD}=3 \times \mathrm{S}_{\text {branco }} / \mathrm{m}
$$

onde:

$S_{\text {branco }}=$ estimativa do desvio padrão do branco de 20 leituras do branco

$M=$ Coeficiente angular da curva analítica (sensibilidade do aparelho).

\subsection{3 - Limite de quantificação}

O limite de quantificação corresponde à menor quantidade do analito passivel de quantificação com exatidão e fidelidade determinada nas condições experimentais determinadas. Ele pode ser estimado por meio do sinal/ruído, do desvio padrão e por processos estatísticos.

O procedimento sinal e ruido pode ser aplicado somente para processos analíticos que exibem linha de base. Efetua-se a determinação da razão sinal ruido, por meio da comparação dos sinais medidos da amostra com baixas concentrações conhecidas do analito com as do branco. Estabelecendo-se a 
concentração mínima na qual o analito pode ser quantificado. Segundo Francotte et al. (1996), o limite de quantificação é definido como sendo 10 vezes o sinal do ruido.

A fórmula para calcular o limite de quantificação está expressa na eq.(15).

$$
L Q=10 \times(s / S)
$$

Onde:

$\mathrm{s}=$ desvio-padrão da resposta

$\mathrm{S}=\mathrm{O}$ coeficiente angular do gráfico de calibração

\subsection{4 - Curva analítica}

Para se definir adequadamente a relação entre concentração e resposta ao analito, é necessário realizar um número suficiente de análises das soluções dos padrões. A curva analítica deve ser construida com, no minimo, 5 pontos na faixa das concentrações esperadas. Cada solução-padrão é preparada por adição de um volume apropriado das soluções estoque, devendo este volume ser sempre menor ou igual a $2 \%$ do volume total das amostras Bressole et al. (1996).

Embora alguns procedimentos analíticos possam requerer o uso de calibração não-linear, é usual utilizar-se de um modelo linear com procedimento de parâmetro-padrão baseado na metodologia dos "mínimos guadrados". Nesta aproximação, a variável independente $(x)$ é a concentração; a variável dependente (Y) é a resposta do detector.

\subsection{5 - Intervalo de trabalho}

O intervalo do método analitico corresponde à faixa do maior ao menor nivel que possa ser determinado com precisão e exatidão, usando a linearidade do método (BRITO, 2001). Os analistas, selecionam o intervalo de trabalho, 
baseado, no nível de concentração do analito que desejam estudar, e depois é determinado se a relação sinal versus concentração é linear.

\subsection{6 - Linearidade}

A linearidade é a habilidade de um método analítico gerar resultados proporcionais à concentração do composto em questão, dentro de uma faixa analitica especificada, intervalo dinâmico, sendo possivel relacionar a resposta do detector à concentração.(CASS, 2001; RIBANI, 2004).

A linearidade é avaliada por intermédio de medidas da amostra em diversas concentrações, ou seja da construção da curva analítica.

A diretriz da International Conference on Harmonization (ICH, 1997) especifica um mínimo de 5 níveis de concentrações. Recomenda-se a análise das amostras em replicata $(n \geq 2)$ (CASS, 2001).

A aceitabilidade dos dados da linearidade é, freqüentemente, julgada pela análise do coeficiente de correlação e pela intercepção do eixo dos Y pela linha de regressão linear, apresentado pelo gráfico de reposta do detector versus concentração. Um coeficiente de correlação maior do que 0,99 é, geralmente, considerado uma evidência aceitável do ajuste dos dados para a regressão linear (CASS, 2001; RIBANI, 2004).

\subsection{7 - Exatidão}

A exatidão de uma medida está relacionada com o seu erro absoluto, isto é, com a proximidade do valor medido em relação ao valor verdadeiro da grandeza, ou, seja está relacionada com a veracidade das medidas Baccan et al. (1979). Ela é definida como a relação entre o valor encontrado pelo método e o valor aceito como verdadeiro ou de referência, sendo calculada pela eq.(16).

Exatidão $=\left(\right.$ concentração $_{\text {obtida }} /$ concentraçãoteórica $) \times 100 \%$ 
A exatidão pode ser determinada de várias formas:

- Análise de uma amostra certificada e sua comparação com o valor medido.

- Comparação com os resultados obtidos por intermédio da utilização de um método já existente e de exatidão conhecida.

- Baseando-se na preparação de uma solução de concentração conhecida, por intermédio da adição de uma determinada quantidade da amostra à matriz.

A exatidão é normalmente determinada por intermédio de, no mínimo, análises em um quinto ponto mais diluído da curva analitica, outra em média (40\%-60\% do ponto mais concentrado e uma em alta $(75 \%-95 \%$ do ponto mais concentrado).

\section{1 .8 - Precisão}

A precisão é a habilidade do método de reproduzir o mesmo resultado, embora não necessariamente o correto, sempre que o procedimento é executado. Ela está relacionada com a concordância das medidas entre si, ou seja, quanto maior a dispersão dos valores, menor a precisão Baccan et. al. (1979). Esta variável pode ser expressa de várias maneiras, mas sabe-se que quanto maior a grandeza dos desvios, menor a sua precisão.

De acordo com a (ICH, 1997), a precisão deveria ser desenvolvida em três niveis: repetibilidade, precisão intermediária e reprodutibilidade.

A repetibilidade é o resultado do método operando sobre o intervalo de tempo curto, sob as mesmas condições, precisão intra-ensaio, Ribani et al. (2004). Ela mede o grau de variação de uma série de replicatas de injeção, em uma mesma seqüência, nas condições originais do método, Cass e Degani (2001). O procedimento anterior é as vezes considerado como uma avaliação da repetibilidade do equipamento. É um procedimento desnecessário quando se trabalha com auto-injetor, a menos que se queira certificar o equipamento. Quando envolve a preparação de múltiplas amostras de mesma 
concentração é denominada precisão intradia, por intermédio da qual se avalia o método em questão.

A precisão intermediária expressa o efeito das variações dentro do laboratório devido a análises ser realizadas em diferentes dias não consecutivos. Pode incluir medidas feitas em diferentes equipamentos, por diferentes analistas, e envolve a preparação de múltiplas amostras (BRITO, 2001).

A reprodutibilidade expressa a precisão entre laboratórios, mediante estudo coloborativos, usualmente aplicados para a padronização de metodologias, Cass e Degani (2001).

A precisão de um método é determinada por intermédio do desvio-padrão ou do coeficiente de variação das medidas obtidas e são calculados usando as equações 16 e 17, onde sd é o desvio padrão, xi é o valor da área obtida, X é o valor médio das áreas, $\mathrm{N}$ é o número de medidas e $\mathrm{CV}$ é o coeficiente de variação.

$$
\begin{aligned}
& s d=\sqrt{\frac{\sum\left(X_{t}-\bar{X}\right)^{2}}{n-1}} \\
& c v=\frac{s d}{\bar{X}} \times 100
\end{aligned}
$$

\subsection{9 - Fator de recuperação}

O fator de recuperação é um número determinado estatisticamente em testes de erros para avaliar perdas durante o processamento analítico. O uso do fator de recuperação é recurso válido e o fator, quando bem determinado, pode ser multiplicado pelo valor obtido e com isso passa ser aceito em termos de precisão, para eliminar os erros sistemáticos (POLITO, 2002).

Toda amostra que recebe tratamento de análise indireta, diluição, extração, concentração, derivação, mudança de estado de oxidação ou, preparo especiação, deve ter calculado experimentalmente o erro ou perda da espécie em 
análise. Com o fator de recuperação, o resultado fica mais próximo da realidade analitica (LEITE, 2002).

A recuperação avalia a eficiência do método de tratamento da amostra. Sua porcentagem é calculada segundo a eq.(18).

Recuperação $(\%)=($ Valor obtido $/$ Valor adicionado $) \times 100 \%$

A porcentagem de recuperação é determinada por intermédio da comparação de análises em quintuplicata de três concentrações, de amostras extraidas com soluções-padrão não extraidas, as quais representam 100\% de recuperação.

Embora porcentagens de recuperação próximas a 100\% sejam desejadas, admitem-se valores menores, por exemplo de 50-60\%, desde que a recuperação seja precisa e exata Cass e Degani (2001).

\subsubsection{0- Sensibilidade}

A sensibilidade é a habilidade de um método distinguir, com determinado nivel de confiança, duas concentrações próximas. A avaliação da sensibilidade compreende a determinação dos limites de quantificação e deteç̧ão (OLIVEIRA, 2004). Sob o ponto de vista prático, a sensibilidade constitui o coeficiente angular do gráfico analítico (RIBANI, 2003). Ela é determinada pela inclinação da linha de calibração. Um método é sensivel se pequenas variações na concentração causa grande variações na resposta analítica (International Union of Pure and Applied Chemistry, 1976). Este critério expressa a capacidade do procedimento analítico gerar variação no valor da propriedade monitorada ou medida, causada por pequeno incremento na concentração ou quantidade do analito. 


\section{1 .10 - Robustez}

A robustez é a habilidade do método em fornecer resultados inalterados quando sujeito a pequenas, mas estudadas variações nos parâmetros do método e prover indicação da sua dependência durante o uso normal (CASS, 2001; MAROTO, 1999).

A avaliação da robustez pode ser considerada durante a fase de desenvolvimento e depende do tipo de processo em estudo. Nos testes de robustez são aplicados experimentos estatísticos que examinam, simultaneamente, os efeitos de alterações em diferentes variáveis do método. As variáveis que podem ser alteradas em técnicas cromatográficas são, fluxo, temperatura, diferentes tipos de coluna, entre outras Cass e Degani (2001).

Os testes de robustez, em geral, servem para indicar os fatores que podem influenciar, significativamente, a resposta do método estudado. ,

\subsubsection{1 - Considerações finais}

Ao avaliar a precisão e a recuperação, geram-se os controles de qualidade do método, em baixa, média e alta concentração. Esses controles devem possuir concentração dentro da faixa linear utilizada, embora diferentes das concentrações utilizadas para a construção da curva analitica Cass e Degani (2001).

Esses controles de qualidade são avaliados quando da utilização do método, para que se verifique a sua validade. Os parâmetros de validação aqui definidos são os mais utilizados, embora outros parâmetros possam ser empregados em função do problema em questão. Os critérios de aceitação destes parâmetros, entretanto, variam amplamente de acordo com a aplicação à qual o método se refere. 


\section{2 - Materiais e métodos}

3.2.1 - Validação do método de extração e determinação de trialometanos, halocetonas, haloaldéidos e halopicrinas por cromatografia em fase gasosa com detecção por captura de elétrons (DCE).

\subsection{2 - Aparelhos e acessórios}

- Cromatógrafo a gás, da marca VARIAN, modelo $3600 \mathrm{CX}$, equipado com detector de captura de elétrons.

- Coluna capilar de sílica fundida DB1, de $30 \mathrm{~m}$ de comprimento, 0,32 mm de diâmetro interno e espessura do filme de $5 \mu \mathrm{m}$.

- Balões volumétricos de $10 \mathrm{~mL}$, frascos de vidro de $15 \mathrm{~mL}$ com septo de silicone.

- Microsseringa de $10 \mu \mathrm{l}$, com guia.

- Nitrogênio - White Martins.

\subsection{3 - Solventes e reagentes}

- Éter-metil-terc-butirico, grau HPLC - Fisher.

- Ácido ascórbico - Synth.

- Água isenta de compostos orgânicos halogenados

- Padrão interno diclorometano, grau HPLC - Fisher

- Sulfato de sódio anidro - Synth

- Padrão de mistura de trialometanos: ampolas de $1 \mathrm{~mL}$ contendo clorfórmio (CF), bromodiclorometano (BDCM), dibromoclorometano (DBCM) e bromofórmio (BF) contendo $2000 \mu \mathrm{g} \cdot \mathrm{mL}^{-1}$ de cada componente em metanol - (Supelco - lote LB18563).

- Mistura de compostos halogenados volatéis: ampolas de $1 \mathrm{~mL}$ contendo $2000 \mu \mathrm{g} \mathrm{mL}^{-1}$ de cada componente em acetona - Supelco - lote N LB09274). Os componentes são: tricloroacetonitrila, dicloroacetonitrila, 
Capitulo 3

1,1-dicloropropanona, cloropicrina, bromocloroacetonitrila, 1,1,1tricloropropanona, dibromoacetonitrila.

\subsection{5 - Validação do método para a determinação dos subprodutos clorados}

Para assegurar-se da credibilidade dos dados nas análises quantitativas, dos subprodutos clorados, deve-se realizar a validação do método em questão. No presente trabalho considerou-se para validação analitica do método, os fatores curva de analítica e linearidade, precisão e fator de recuperação.

\subsubsection{1- Condições cromatográficas otimizadas para análise dos subprodutos da oxidação}

As análises foram feitas em um cromatógrafo gasoso da marca Varian, modelo $3600 \mathrm{CX}$, equipado com detector de captura de elétrons (ECD), coluna capilar de sílica fundida J\&W-DB-1, $30 \mathrm{~m}$ de comprimento, 0,32 mm de diâmetro interno e filme de $5 \mu \mathrm{m}$ de espessura.

As condições cromatográficas otimizadas e utilizadas para todas as análises foram as descritas a seguir:

- Temperatura do injetor: $160^{\circ} \mathrm{C}$.

- Temperatura da coluna: $150{ }^{\circ} \mathrm{C}$.

- Fluxo do gás de arraste $\left(\mathrm{N}_{2}\right): 3,6 \mathrm{~mL} \cdot \mathrm{min}^{-1}$.

- Temperatura do detector: $290{ }^{\circ} \mathrm{C}$.

- Divisão de amostra $2,0 \mathrm{~mL} \min ^{-1}$.

- Programação da temperatura: inicialmente a $40{ }^{\circ} \mathrm{C}$ mantida por 1 minuto, aumentando $5{ }^{\circ} \mathrm{C} \cdot \min ^{-1}$ até $125{ }^{\circ} \mathrm{C}$ mantida por 2 min e aumentando a $20^{\circ} \mathrm{C} \cdot \mathrm{min}^{-1}$ até $150{ }^{\circ} \mathrm{C}$ mantendo por $1 \mathrm{~min}$. 


\subsubsection{2 - Preparo da curva analítica e linearidade}

Após determinar as melhores condições experimentais partiu-se para a construção das curvas analiticas para os trialometanos e outros compostos orgânicos halogenados volatéis, cloropricrinas, halocetonas e haloaldeídos.

Foram utilizados os padrões da mistura de trialometanos e compostos halogenados volatéis da marca Supelco e cujos lotes são respectivamente de números LB18563 e LB09274. Cada ponto da curva analítica foi preparado da seguinte maneira, adicionou-se $\mathrm{H}_{2} \mathrm{O}$ em balão de $10 \mathrm{~mL}$, e em seguinte os volumes dos padrões, pré-determinados e completou-se o volume do balão e colocou-se $10 \mu \mathrm{l}$ de uma solução de diclorometano de $1000 \mathrm{mg} \mathrm{L}^{-1}$, padrão interno. Transferiu-se o contéudo do balão para os frascos apropriados e adicionou-se $5 \mathrm{~mL}$ de éter-metil-terc-butirico para a extração dos trialometanos e outros subprodutos clorados. Agitou-os e após os mesmos foram deixados em repouso e separou-se a fase orgânica. Para a retirada completa da água na fase orgânica adicionou-se o agente secante sulfato de sódio anidro a fase orgânica. A fase orgânica foi guardadas em frascos especiais e conservadas na geladeira a uma temperatura de $2^{\circ} \mathrm{C}$ para posteriores análises.

As curvas de analiticas foram preparadas com seis pontos, onde cada ponto foi preparado em triplicada, contendo as respectivas concentrações de 2; 5; 20; 30; 40 e $50 \mu \mathrm{g} \mathrm{L}^{-1}$ dos subprodutos clorados.

\subsubsection{3 - Precisão e recuperação}

A determinação da precisão e ensaios de recuperação foram realizados da em quintuplicata, em três níveis de concentrações: 10, 25 e $45 \mu \mathrm{g} \mathrm{L}^{-1}$. Estes valores foram selecionados por possuirem concentrações dentro da faixa linear utilizada, porém diferentes das concentrações utilizadas na curva analítica 


\section{3 - RESULTADOS E DISCUSSÃO}

3.3.1 - Otimização das condições cromatográficas para a determinação de subprodutos clorados

Após serem testadas diversas possibilidades de condições comatográficas para a determinação dos subprodutos clorados, obteve-se a melhor separação e resolução dos picos utilizando-se as condições citadas no item 3.2.5.1.

Adotando-se estas condições para a confecção da curva analítica, observou-se que, foi possivel separar bem os THM (cloróformio, bromofórmio, dibromoclorometano, bromodiclorometano) e outros subprodutos clorados como dibromoacetonitrila, dicloroacetonitrila, tricloroacetonitrila, bromocloroacetonitrila, 1,1 - dicloropropanona, 1,1,1 - tricloropropanona e cloropicrina. Como pode se observado pelos cromatogramas apresentados nas Figuras 21 e 22. Verifica-se na Figura 21 o cromatograma do branco, e observa-se que não aparece nenhum pico exceto o do padrão interno, diclorometano (A).

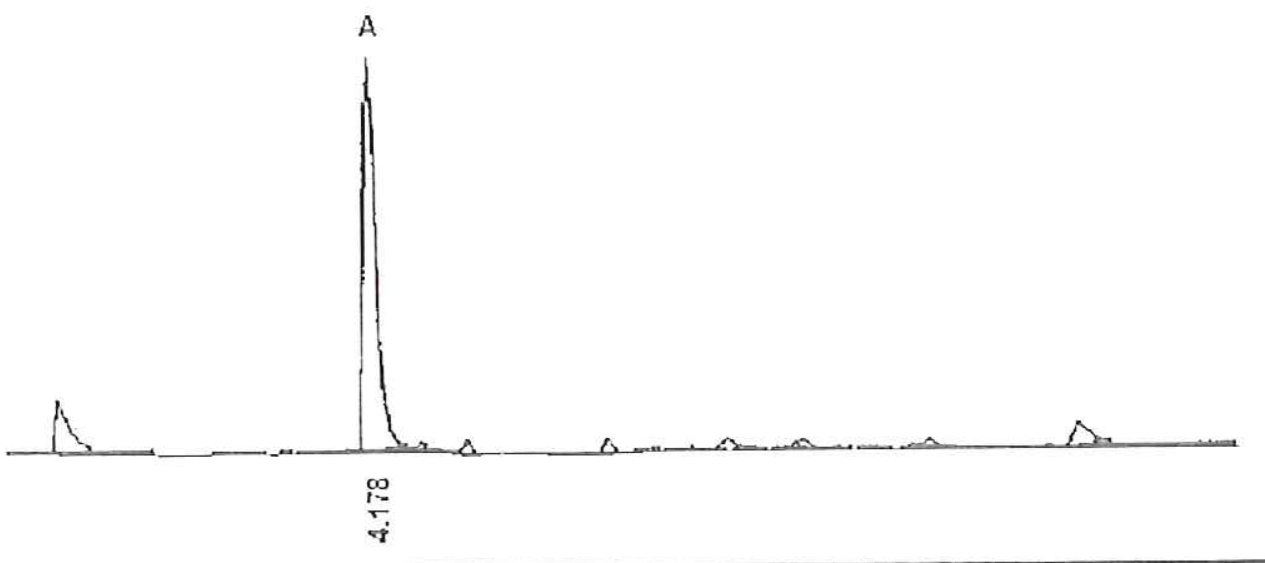

Figura 21 - Cromatograma do branco analítico. (A) - diclorometano 
Na Figura 22 encontra-se apresentado o cromatograma da curva analítica com 50 $\mu \mathrm{g} \mathrm{L}^{-1}$ dos padrões: Legenda: 1- $\mathrm{Pl}$ (diclorometano), 2- clorofórmio, 3 - tricloroacetonitrila,4- dicloroacetonitrila, 5 - bromodiclorometano, 6 - 1,1- dicloropropanona, 7 - cloropicrina, 8 - não identificado, 9 - 1, 1, 1- triclorometano, 10 - bromocloroacetonitrila, 11 - dibromoacetonitrila, 12 - não identificado.

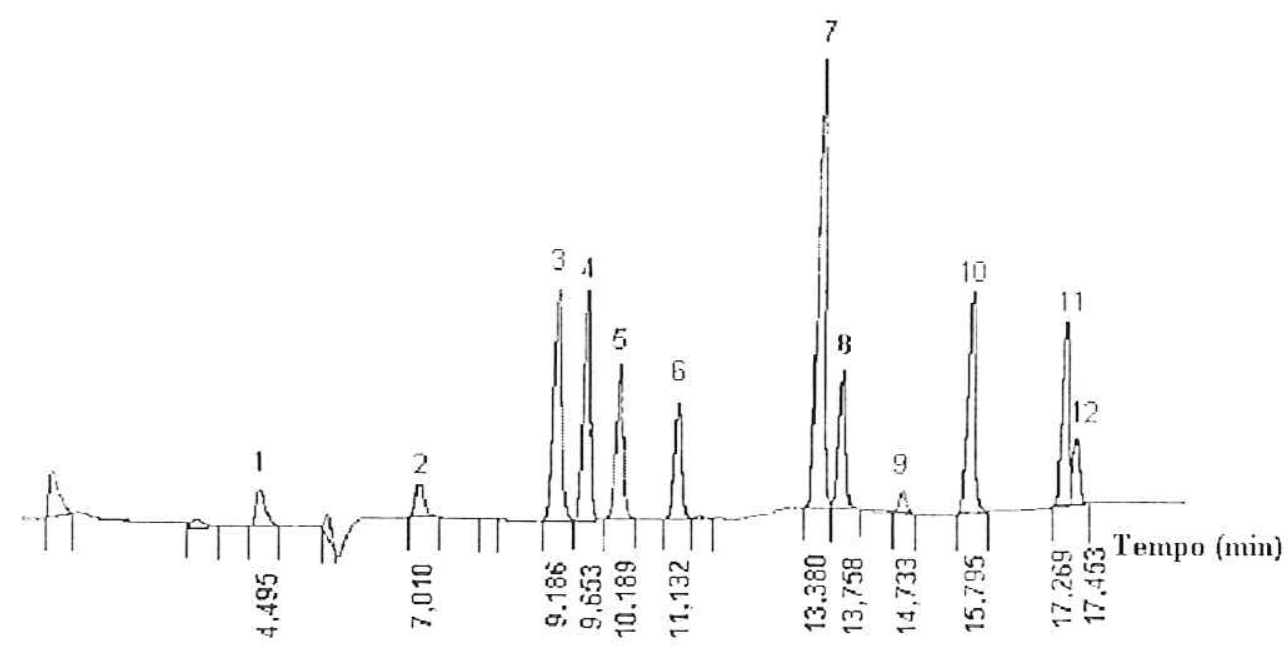

Figura 22 - Cromatograma da curva analítica com $50 \mu \mathrm{g} \mathrm{L}^{-1}$.

3.3.2 - Estudo da linearidade e da resposta do detector de captura de elétrons

Para a confecção das curvas analíticas e análises das amostras contendo os subprodutos clorados foi utilizado o método do padrão interno. O padrão interno utilizado foi o diclorometano e as curvas analíticas foram preparadas com seis pontos, onde cada ponto foi preparado em triplicada, contendo as respectivas concentrações de $2 ; 5 ; 20 ; 30 ; 40$ e $50 \mu \mathrm{g} \mathrm{L}^{-1}$ dos compostos citados no item (3.3.1).

O método de regressão linear foi aplicado para a obtenção das curvas analiticas. Nas Figuras 23, 24 e 25 encontram-se apresentadas as curvas para o cloróformio, 1,2- dicloropropanona e tricloroacetonitrila e na 
Tabela 14 encontram-se apresentados os coeficientes de correlações e as equações das retas para os demais subprodutos clorados presentes.

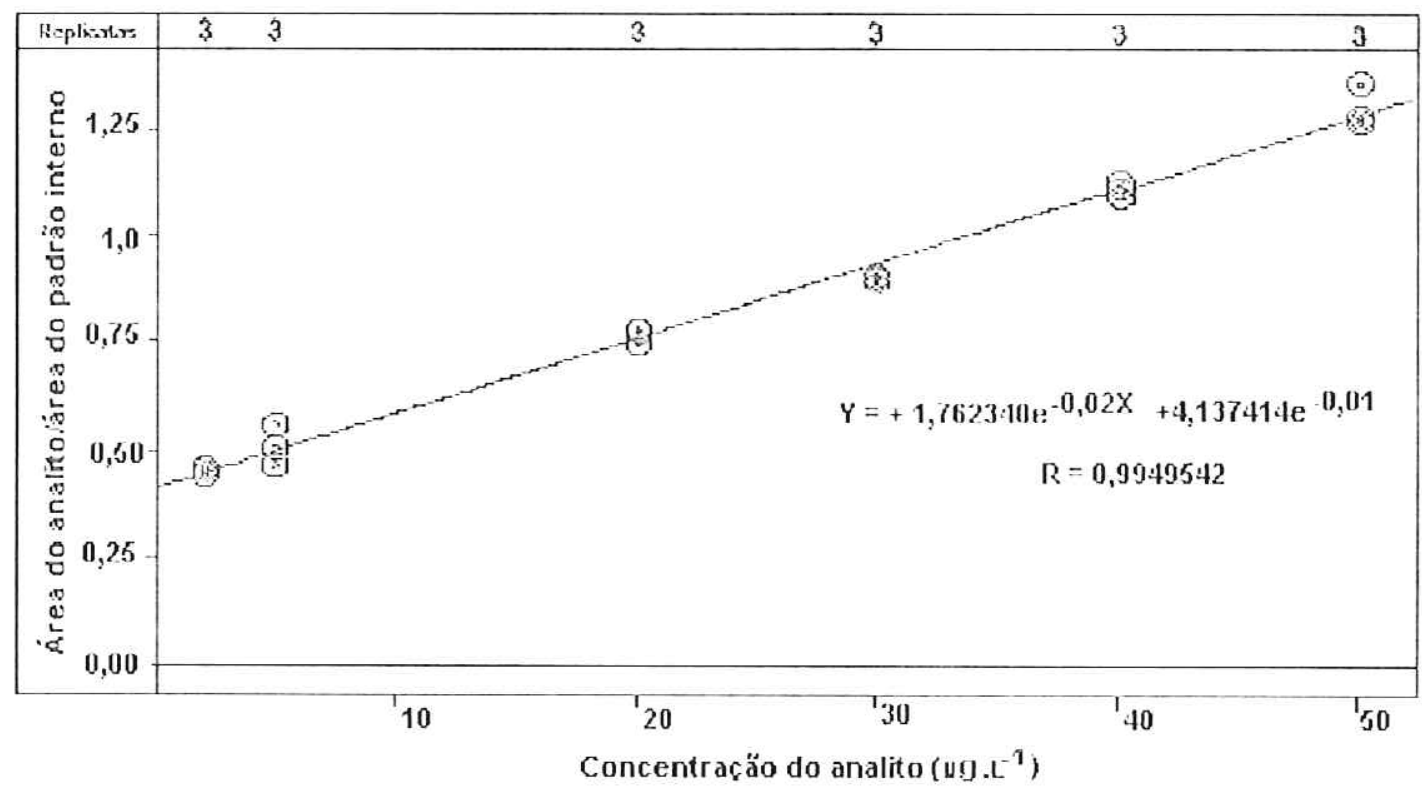

Figura 23- Curva analítica obtida para o clorofórmio.

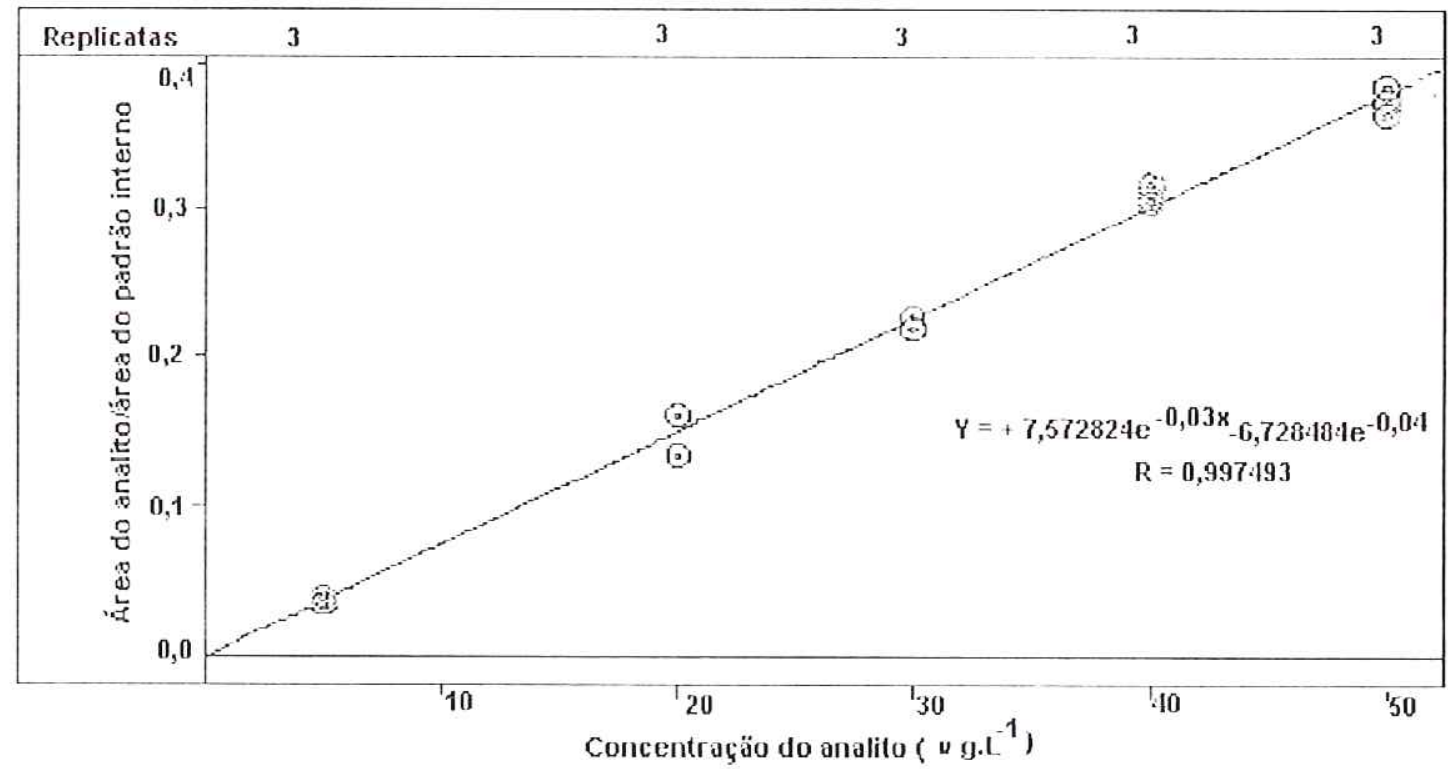

Figura 24 - Curva analítica obtida para a 1,1,1-tricloropropanona. 


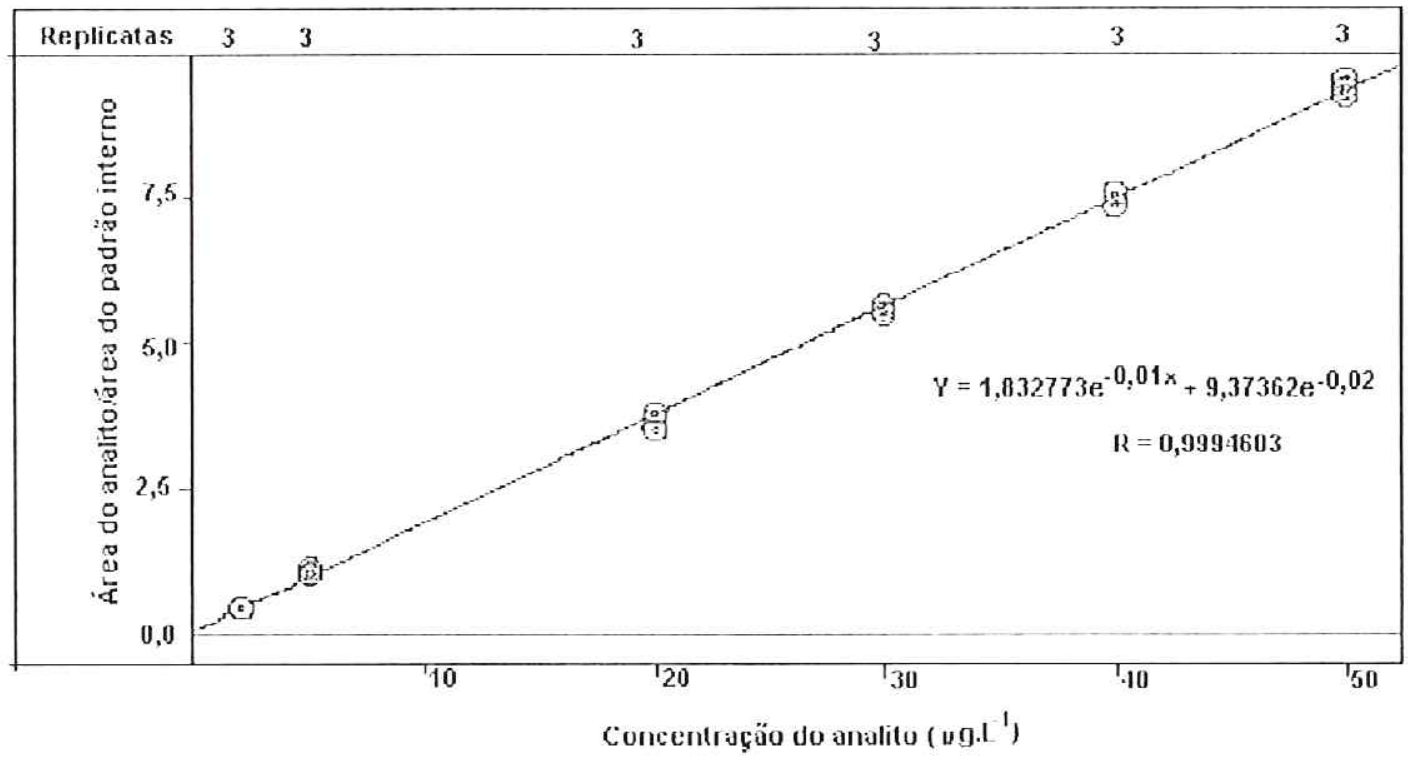

Figura 25 - Curva analítica obtida para a tricloroacetonitrila.

Tabela 14 - Coeficientes de correlações e equações das retas obtidas para os subprodutos clorados.

\begin{tabular}{|c|c|c|}
\hline $\begin{array}{c}\text { Subprodutos } \\
\text { clorados }\end{array}$ & $\begin{array}{c}\text { Coeficientes de } \\
\text { correlacões }\end{array}$ & Equações das retas \\
\hline \hline bromocloroacetonitrila & 0,9959332 & $\mathrm{Y}=+7,976692 \mathrm{e}^{-0,02 x}+1,150709 \mathrm{e}^{-0,01}$ \\
\hline Dicloroacetonitrila & 0,9988913 & $\mathrm{Y}=+1,008429 \mathrm{e}^{-0,01 x}+1,372185 \mathrm{e}^{-0,01}$ \\
\hline dibromoacetonitrila & 0,9989654 & $\mathrm{Y}=+8,173425 \mathrm{e}^{-0,02 x}+7,971872 \mathrm{e}^{-0,02}$ \\
\hline cloropicrina & 0,9991366 & $\mathrm{Y}=+2,383194 \mathrm{e}^{-0,01 x}+1,961595 \mathrm{e}^{-0,01}$ \\
\hline dibromoclorometano & 0,9986856 & $\mathrm{Y}=+9,862538 \mathrm{e}^{-0,02 x}+1,583543 \mathrm{e}^{-0,01}$ \\
\hline bromodiclorometano & 0,9991686 & $\mathrm{Y}=+1,110155 \mathrm{e}^{-0,01 x}+2,794224 \mathrm{e}^{-0,01}$ \\
\hline bromofórmio & 0,9979328 & $\mathrm{Y}=+4,023773 \mathrm{e}^{-0,02 x}+6,904806 \mathrm{e}^{-0,02}$ \\
\hline 1,1-dicloropropanona & 0,9986896 & $\mathrm{Y}=+5,399945 \mathrm{e}^{-0,02 x}+7,368716 \mathrm{e}^{-0,02}$ \\
\hline
\end{tabular}


Capitulo 3

A Agência Nacional de Vigilância Sanitária (ANVISA, 2003) recomenda um coeficiente de correlação igual a 0,99 e o Instituto Nacional de Metrologia, Normalização e Qualidade Industrial (INMETRO, 2003) um valor acima de 0,90.

Analisando-se os dados apresentados nas Figuras 23, 24 e 25 e na Tabela 14, observa que todos os compostos apresentaram coeficientes de correlação maior que 0,99, ou seja um coeficiente de correlação satisfatório (RIBANI, 2004), o que indica que o detector utilizado responde bem às concentrações analisadas, e é linear na faixa de interesse estudada.

\section{Precisão do método}

$\mathrm{Na}$ Tabela 15 encontram-se apresentados os resultados de precisão do método empregado para a determinação dos subprodutos clorados. 
Tabela 15 -Resultados do estudo da precisão do método para a determinação de subprodutos clorados.

\begin{tabular}{|c|c|c|c|c|c|}
\hline Composto & $\begin{array}{l}\text { Conc. } \\
\left(\mu \mathrm{g} \mathrm{L}^{-1}\right)\end{array}$ & $\begin{array}{l}\text { Conc. } \\
\text { média* } \\
\left(\mu \mathrm{g} \mathrm{L}^{-1}\right)\end{array}$ & $\begin{array}{c}\text { Estimativa } \\
\text { do desvio } \\
\text { padrão }\end{array}$ & $\begin{array}{l}\text { Tenden- } \\
\text { ciosidade }\end{array}$ & $\begin{array}{l}\text { CV } \\
(\%)\end{array}$ \\
\hline \multirow{3}{*}{ clorofórmio } & 10 & 10,02 & 0,89 & 0,02 & 8,88 \\
\hline & 25 & 25,09 & 0,76 & 0,36 & 3,02 \\
\hline & 45 & 45,69 & 1,45 & 1,54 & 3,16 \\
\hline \multirow{3}{*}{ bromodiclorometano } & 10 & 9,36 & 0,36 & $-6,40$ & 3,89 \\
\hline & 25 & 25,39 & 0,55 & 1,55 & 2,18 \\
\hline & 45 & 47,12 & 1,62 & 4,71 & 3,44 \\
\hline \multirow{3}{*}{ dibromoclorometano } & 10 & 9,89 & 0,63 & $-1,20$ & 6,38 \\
\hline & 25 & 25,63 & 0,79 & 2,54 & 3,07 \\
\hline & 45 & 47,54 & 1,64 & 5,64 & 3,45 \\
\hline \multirow{3}{*}{ bromofórmio } & 10 & 10,25 & 0,80 & 2,46 & 7,78 \\
\hline & 25 & 26,32 & 0,90 & 5,29 & 3,44 \\
\hline & 45 & 47,47 & 1,63 & 5,48 & 3,44 \\
\hline \multirow{3}{*}{ dicloroacetonitrila } & 10 & 10,95 & 0,65 & 9,54 & 5,92 \\
\hline & 25 & 25,69 & 0,73 & 2,76 & 2,85 \\
\hline & 45 & 47,52 & 1,74 & 5,59 & 3,66 \\
\hline \multirow{3}{*}{ tricloroacetonitrila } & 10 & 10,31 & 0,38 & 3,14 & 3,66 \\
\hline & 25 & 22,69 & 0,48 & $-9,23$ & 2,10 \\
\hline & 45 & 46,51 & 1,90 & 3,35 & 4,09 \\
\hline \multirow{3}{*}{ bromodicloroacetonitrila } & 10 & 12,26 & 0,95 & 22,58 & 7,74 \\
\hline & 25 & 28,54 & 1,19 & 14,17 & 4,17 \\
\hline & 45 & 49,06 & 2,80 & 9,02 & 5,71 \\
\hline \multirow{3}{*}{ dibromoacetonitrila } & 10 & 11,57 & 0,86 & 6,94 & 8,02 \\
\hline & 25 & 24,11 & 0,95 & $-1,34$ & 3,82 \\
\hline & 45 & 48,06 & 1,37 & 2,78 & 2,96 \\
\hline
\end{tabular}


Tabela 15 -Resultados do estudo da precisão do método utilizado para a determinação dos subprodutos clorados.

\begin{tabular}{|c|c|c|c|c|c|}
\hline Composto & $\begin{array}{c}\text { Conc. } \\
\left(\mu \mathrm{g} \mathrm{L}^{-1}\right)\end{array}$ & $\begin{array}{c}\text { Conc. } \\
\text { média* }^{*} \\
\left(\mu \mathrm{g} \mathrm{L}^{-1}\right)\end{array}$ & $\begin{array}{c}\text { Estimativa } \\
\text { do desvio } \\
\text { padrão }\end{array}$ & $\begin{array}{c}\text { Tenden- } \\
\text { ciosidade }\end{array}$ & $\begin{array}{c}\mathrm{CV} \\
(\%)\end{array}$ \\
\hline \multirow{2}{*}{ cloropicrina } & 10 & 10,46 & 0,54 & 4,62 & 5,17 \\
& 25 & 23,85 & 0,76 & $-4,59$ & 3,17 \\
& 45 & 46,78 & 2,20 & 3,96 & 4,70 \\
\hline \multirow{3}{*}{ 1,1-dicloropropanona } & 10 & 11,43 & 0,65 & 14,30 & 5,70 \\
& 25 & 27,11 & 0,87 & 8,46 & 3,22 \\
\hline \multirow{2}{*}{ 1,1,1- tricloropropanona } & 25 & 48,99 & 1,92 & 8,88 & 3,91 \\
& 10 & 10,67 & 1,03 & 6,66 & 9,67 \\
& 45 & 24,78 & 1,21 & $-0,89$ & 4,90 \\
\hline
\end{tabular}

* média de 5 determinações

A precisão em validação de métodos é considerada em três níveis diferentes: repetibilidade, precisão intermediária e reprodutibilidade.

Neste estudo a precisão do método foi avaliada referente ao nível de repetivilidade. A repetividade apresenta a concordância entre os resultados de medidas sucessivas de um mesmo método, efetuadas sob as mesmas condições que são chamadas condições de repetividade: mesmo procedimento; mesmo analista; mesmo instrumento usado sob as mesmas condições; mesmo local; repetições em curto intervalo de tempo.

A International Conference on Harmonisation ( $\mathrm{ICH}, 1995)$ e a Agência Nacional de Vigilância Sanitária (ANVISA, 2003) sugerem que a repetividade seja verificada a partir de um mínimo de nove determinações cobrindo o limite especificado do procedimento, três niveis, três repetições para cada um, ou a partir de um mínimo de seis determinações a uma concentração similar ao valor esperado (RIBANI, 2004). As analises foram realizadas em quintuplicata de três diferentes concentrações 10; 25 e $45 \mu \mathrm{g} \mathrm{L}^{-1}$. 
Analisando-se a Tabela 15 observou-se que os coeficientes de variação ficaram no intervalo de 2,10 a 9,68, o que indica que o método é preciso, pois segundo (RIBANI, 2004) em métodos de analises de traços são aceitos valores do coeficiente de variação de até $20 \%$, dependendo da complexidade da amostra.

Segundo (OLIVER, 1989) os métodos que utilizam a extração liquido-líquido para a analise de compostos voláteis como os trialometanos apresentam um coeficiente de variação (CV) em torno de 7 a 14\%. De acordo com as considerações anteriormente descritas, os valores de CV obtidos e apresentados na Tabela 13, mostraram que o método de determinação de subprodutos clorados em água por extração liquido-líquido e cromatografia em fase gasosa com deteç̧ão por captura de elétrons, apresentou precisão para a determinação dos trialometanos e demais subprodutos clorados. O maior valor do CV, foi de $9,67 \%$ para a tricloropropanona.

Segundo (WOOD, 1999) o método é considerado preciso quando apresentar níveis de variações dentro do aceitável para cada nivel de concentração, conforme apresentado na Tabela 16.

Tabela 16 - Coeficientes de variação em função do nivel de concentração do analito (WOOD, 1999).

\begin{tabular}{c|c}
\hline Concentração do analito (\%) & Coeficiente de variação (\%) \\
\hline $1(100 \%)$ & 2,0 \\
\hline $10^{-1}$ & 2,8 \\
\hline $10^{-2}(1 \%)$ & 4,0 \\
\hline $10^{-3}$ & 5,6 \\
\hline $10^{-4}$ & 8,0 \\
\hline $10^{-5}$ & 11,0 \\
\hline $10^{-6}(\mathrm{ppm})$ & 16,0 \\
\hline $10^{-7}$ & 23,0 \\
\hline $10^{-8}$ & 32,0 \\
\hline $10^{-9}(\mathrm{ppb})$ & 45,0 \\
\hline
\end{tabular}


Comparando os resultados apresentados na Tabela $15 \mathrm{com}$ os dados da 16, tem-se a confirmação de que o método é preciso.

\subsection{3 - Exatidão e recuperação do método}

Para avaliar a exatidão e a recuperação dos subprodutos clorados descritos no item (3.3.1) pode-se calcular as médias dos três niveis de fortificação. A exatidão refere-se à concordância entre a concentração real do analito e a encontrada no procedimento analítico. Uma tendenciosidade (positiva ou negativa) é observada quando erros sistemáticos estão presentes alterando a exatidão metodológica. Pode ser determinada através da eq.(19).

Tendenciosidade $=($ Conc do analito encontrada - conc do analito adicionado/conc do analito adicionado) $\times 100$

Os resultados de recuperação média, tendenciosidade e estimativa do desvio padrão para cada subproduto clorado analisado em matrizes aguosas encontram-se apresentados na Tabela 17.

De maneira geral, para métodos cromatográficos, preconiza-se uma exatidão de até $20 \%$ (tendenciosidade $\pm 20 \%$ ) do valor real e precisão menor que. 15\% (CAUSON, 1997; CHASIN, 1994).

Em relação a exatidão do método, visualizado através dos valores de tendenciosidade apresentados na Tabela 17, pode concluir que o método apresenta uma boa exatidão.

Os resultados de recuperação mostraram valores que variam de 90,77 a $122,58 \%$, com estimativa dos desvios relativos de 0,36 a 2,8 para $(n=5)$ para os subprodutos clorados estudados.

A recuperação do método está relacionada à exatidão uma vez que reflete a quantidade de uma determinada substância recuperada em processo analítico (CAUSON, 1997; CHASIN, 1994). 
Neste estudo obteve-se niveis de recuperação em torno de $100 \%$ para os compostos apresentados na Tabela 17.

Tabela 17- Valores de porcentagem de recuperação dos trialometanos e outros subprodutos clorados.

\begin{tabular}{|c|c|c|c|c|}
\hline \multirow[t]{2}{*}{ Composto } & \multirow{2}{*}{$\begin{array}{l}\text { Concentração } \\
\text { adicionada } \\
\left(\mu \mathrm{L}^{-1}\right)\end{array}$} & \multirow{2}{*}{$\begin{array}{c}\text { Concentração } \\
\text { média* } \\
\text { encontrada } \\
\left(\mu \mathrm{g} \mathrm{L}^{-1}\right)\end{array}$} & \multicolumn{2}{|c|}{ Recuperação (\%) } \\
\hline & & & Média & $( \pm s)$ \\
\hline \multirow{3}{*}{ clorofórmio } & 10 & 10,002 & 100,02 & 8,88 \\
\hline & 25 & 25,09 & 100,36 & 3,03 \\
\hline & 45 & 45,694 & 101,54 & 3,21 \\
\hline \multirow{3}{*}{ bromodiclorometano } & 10 & 9,36 & 93,60 & 3,64 \\
\hline & 25 & 25,39 & 101,55 & 2,21 \\
\hline & 45 & 47,12 & 104,70 & 3,60 \\
\hline \multirow{3}{*}{ dibromoclorometano } & 10 & 9,88 & 98,80 & 6,30 \\
\hline & 25 & 25,63 & 102,53 & 3,14 \\
\hline & 45 & 47,54 & 105,63 & 3,64 \\
\hline \multirow{3}{*}{ bromofórmio } & 10 & 10,25 & 102,46 & 7,97 \\
\hline & 25 & 26,32 & 105,28 & 3,62 \\
\hline & 45 & 47,47 & 105,48 & 3,62 \\
\hline \multirow{3}{*}{ dicloroacetonitrila } & 10 & 10,95 & 109,54 & 6,48 \\
\hline & 25 & 25,69 & 102,76 & 2,93 \\
\hline & 45 & 47,52 & 105,59 & 3,86 \\
\hline \multirow{3}{*}{ tricloroacetonitrila } & 10 & 10,31 & 103,14 & 3,78 \\
\hline & 25 & 22,69 & 90,77 & 1,91 \\
\hline & 45 & 46,51 & 103,35 & 4,23 \\
\hline \multirow{3}{*}{ Bromocloroacetonitrila } & 10 & 12,26 & 122,58 & 9,49 \\
\hline & 25 & 28,54 & 114,17 & 4,76 \\
\hline & 45 & 49,06 & 109,02 & 6,23 \\
\hline \multirow{3}{*}{ dibromoacetonitrila } & 10 & 11,57 & 106,94 & 8,58 \\
\hline & 25 & 24,11 & 98,66 & 3,77 \\
\hline & 45 & 48,06 & 102,78 & 3,05 \\
\hline \multirow{3}{*}{ cloropicrina } & 10 & 10,46 & 104,62 & 5,41 \\
\hline & 25 & 23,85 & 95,41 & 3,02 \\
\hline & 45 & 46,78 & 103,96 & 4,88 \\
\hline \multirow{3}{*}{ 1,1-dicloropropanona } & 10 & 11,43 & 114,30 & 6,51 \\
\hline & 25 & 27,11 & 108,46 & 3,50 \\
\hline & 45 & 48,99 & 108,88 & 4,26 \\
\hline \multirow{3}{*}{ 1,1,1- tricloropropanona } & 10 & 10,67 & 106,66 & 10,31 \\
\hline & 25 & 24,78 & 99,11 & 4,85 \\
\hline & 45 & 46,74 & 103,88 & 5,49 \\
\hline
\end{tabular}




\section{4 - CONCLUSÕES}

A validação é essencial para definir se os métodos desenvolvidos estão completamente adequados aos objetivos a que se destinam, a fim de se obter resultados confiáveis que possam ser satisfatoriamente interpretados. A validação foi obtida com sucesso, porque os parâmetros determinados se enguadram-se nos valores estabelecidos pela Anvisa e Inmetro . O método para determinação dos subprodutos da oxidação apresentou uma excelente linearidade e uma boa precisão, com isso, conclui-se que a metodologia desenvolvida é eficaz e pode ser utilizada no monitoramento dos subprodutos da oxidação.

\section{5 - CONSIDERAÇÕES A RESPEITO DO CAPITULO 3}

No capítulo 3 foi realizada a validação do método analítico. Esta foi feita para garantir a confiabilidade do método aplicado. Deve-se ter em mente que sem validação, tem-se apenas um número e não um resultado. Após desenvolvido e validado o método este foi utilizado para a determinação dos subprodutos da oxidação que constam no capítulo 4. 


\section{CAPITULO - 4}

Determinação dos subprodutos formados durante a oxidação da água, contendo substâncias, com os oxidantes cloro e dióxido de cloro.

\section{4 - INTRODUÇÃO}

É fato notório, e de reconhecimento da Organização Mundial da Saúde (OMS), que o fornecimento da água em quantidade suficiente e que atenda os padrões de potabilidade a uma comunidade consiste numa das medidas de atenção primária da saúde da mesma, em virtude dos efeitos benéficos diretos que tal produz Sanches et al. (2003a). É necessário realizar o controle de qualidade da água para que se possa assegurar a saúde da população, pois ela é considerada como o vetor de muitas doenças (AZEVEDO NETO, 1987). O homem necessita de água de qualidade adequada e em quantidade suficiente para todas as suas necessidades, não só atender suas necessidades físicas, assim como também o desenvolvimento econômico, sendo importante relembrar que são muitos os prejuizos econômicos que podem advir da má qualidade da água.

A água destinada ao consumo humano deve preencher as condições mínimas para que possa ser ingerida ou utilizada para fins higiênicos, o que se consegue por meios de estações de tratamento (DI BERNARDO, 1995). O controle da qualidade da água é uma atividade de caráter dinâmico e que deve ser exercido, tanto no meio urbano como no meio rural. Em outras palavras, o controle de qualidade da água deve ser considerado em todas as etapas do serviço de abastecimento, desde o manancial, captação, recalque, adução, tratamento e distribuição, terminando na torneira (AZEVEDO NETTO, 1987).

No Brasil, a desinfecção da água para consumo humano é usualmente realizada com a adição de cloro, nas formas de gás cloro e hipoclorito de sódio (DI BERNARDO, 1995). Estudos recentes têm demonstrado que a adição de cloro livre à água bruta pode trazer certos inconvenientes, como a formação de trialometanos (THM) que são substâncias carcinogênicas e de outros subprodutos 
clorados também resultantes do processo de cloração da água e mais perigosos que os (THM) Sarzanini et al. (1999). Os THM são compostos organoclorados formados a partir da interação do cloro residual livre com as substâncias resultantes da degradação de vegetais, denominadas substâncias húmicas (precursores) Mutamara et al. (1995). Sabe-se também, que compostos aromáticos presentes nas $\mathrm{SH}$, são substratos fortemente reativos em reações de substituição e oxidação. Ambas reações são típicas na cloração aguática, resultando na formação de compostos organoclorados Dianova et al. (2000). A formação de subprodutos clorados é representada pela eq.(20) (MACEDO, 1997).

Cloro residual livre + precursores $\rightleftharpoons$ THM + outros subprodutos (20)

(substâncias húmicas)

Alguns dos principais subprodutos clorados que podem ser formados são (DI BERNARDO, 1995):

Trialometanos (THM): clorofórmio, bromodiclorometano, dibromoclorometano, bromofórmio.

Ácidos Haloacéticos (AHA): ácidos monocloroacético, dicloroacético, tricloroacético, monobromoacético, dibromoacético, tribromoacético, bromocloracético, bromodicloacético, dibromocloracético

Haloacetonitrilas (HAN): dicloroacetonitrila, tricloroacetonitrila, dibromoacetonitrila, tribromoacetonitrila, bromocloroacetonitrila.

Haletos Cianogênicos (HC): cloreto cianogênico, brometo cianogênico.

Halopicrinas ( HP): cloropicrina, bromopicrina

Haloacetonas (HK): 1,1-dicloropropanona, 1,1,1-tricloropropanona, 1,1-dicloro-2-butanona, 3,3-dicloro-2-butanona, 1,1,1-tricloro-2-butanona.

Haloaldeidos (HAD): dicloacetaldeido, tricloroacetaldeido.

Halofenóis (HF): 2-clorofenol, 2,4-diclorofenol, 2,4,6-triclorofenol.

Em estudo realizado nos Estados Unidos em 1974, apresentou pela primeira vez a correlação positiva entre águas de abastecimento público e o 
câncer (MACEDO, 1997). Várias pesquisas foram desenvolvidas, das quais destaca-se a realizada pela U.S. Enviromental Protection Agency (EPA) em 113 estações de tratamento de água (ETA). Foram encontrados trialometanos em todas as ETA que utilizavam derivados clorados nos processos de desinfecção.

Estudos recentes demonstraram que os THM são apenas uma parcela dos subprodutos da desinfecção e que os demais subprodutos halogenados formados podem causar sérios problemas à saúde humana Richardson et al. (2002).

\section{1 - REVISÃO BIBLIOGRÁFICA}

\subsection{1 - Trialometanos}

Dentre os organoclorados, os THM destacam-se em função da sua veiculação realizar-se através da água, que é um líquido indispensável à vida. Os THM são definidos como compostos que apresentam em sua estrutura molecular um átomo de carbono, um de hidrogênio e três átomos de halogênios (Issac, 1993). Dentre os possiveis trialometanos, quatro ganharam destaque em água tratada devido à sua ocorrência em concentrações mais significativas: clorofórmio $\left(\mathrm{CHCl}_{3}\right)$, diclorobromometano $\left(\mathrm{CHBrCl}_{2}\right)$, dibromoclorometano $\left(\mathrm{CHBr}_{2} \mathrm{Cl}\right)$ e bromofórmio $\left(\mathrm{CHBr}_{3}\right)$ (SANTOS, 1987). Portanto, quando se faz referência aos THM, na realidade estão sendo mencionados os quatro compostos anteriormente. O parâmetro THM é medido pela soma das concentrações (em massa) desses quatro THM principais.

Na Figura 26 está apresentado a estrutura molecular dos quatro trialometanos principais. 
<smiles>CC(C)Cl</smiles>

व<smiles>CC(Br)c1ccccc1</smiles>

$\mathrm{Br}$<smiles>CC(Cl)Cl</smiles>

$\mathrm{Er}$<smiles>ClC(Br)Br</smiles>

Dibromótorometann

Figura 26 - Estrutura molecular dos quatro THM principais.

\section{4-1.2 - Fontes de exposição}

Desde a descoberta dos THM, tem-se verificado que a exposição humana ocorre não apenas pela ingestão da água de abastecimento clorada. Quando esta é utilizada para trabalhos domésticos, a população está também exposta durante a lavagem de roupas e louças, durante o banho ou qualquer outras atividade que utilize água tratada Bloemen e Bun (1993). Neste caso, a presença dos THM ocorre em virtude da alta volatilidade que estes apresentam e da lipossolubilidade.

Estudos experimentais indicam que a exposição ao clorofórmio (CF), por inalação, durante um banho de ducha por 8 minutos, pode ser até 6 vezes maior do que pela ingestão da água durante um período de vinte e quatro horas Bloemen e Bun (1993).

A água de piscina clorada é uma outra fonte de exposição aos THM (TOMINAGA, 1998).

Uma vez presentes na água, esses compostos, em virtude de sua volatização, podem apresentar na forma gasosa, no ar ambiente. Os THM já foram detectados em diversos alimentos e bebidas preparados com água clorada, sorvetes, sucos e refrigerantes (TOMINAGA, 1998).

\section{1-3 - Carcinogenicidade}

Estudos realizados nos Estados Unidos em 1974, mostraram pela primeira vez a correlação positiva entre águas de abastecimento público e o câncer, várias 
pesquisas foram desenvolvidas, das quais destaca-se aquela realizada pela U.S. Enviromental Protection Agency (EPA) em 113 estações de tratamento de água (ETA). Trialometanos foram encontrados em todas as ETA que utilizavam derivados clorados nos processos de desinfecção.

Em 1976, estudos realizados nos laboratórios do National Cancer Institute dos EUA comprovaram que o clorofórmio em altas concentrações, maiores que as normalmente encontradas para consumo pode causar câncer em ratos e camundongos.

Apesar de não existir evidências que o cloróformio seja carcinogênico para o homem pode-se considerar que apresente um risco para a exposição humana (TOMINAGA, 1998). Segundo a International Agency for Research on Cancer (IARC) existem evidências inadequadas quanto a carcinogenicidade do clorofórmio para humanos, e evidências suficientes em relação a animais. O bromodiclorometano, dibromoclorometano e o bromofórmio apresentam evidências para a carcinogenicidade limitadas para animais (PITOT III, 1996). Diversos estudos epidemiológicos tem sido realizados (BELLAR, 1974) a fim de se correlacionar a incidência de diversos tipos de câncer e a presença de trialometanos na água de abastecimento. Os dados obtidos sugerem que existem uma alta probabilidade da relação entre câncer de bexiga, cólon e reto e a ingestão desses compostos. Entretanto nenhum dos trabalhos apresentam provas concretas.

\subsection{4 - Aplicação de um valor guia}

Sabe-se que os trialometanos, principalmente o clorofórmio, pode produzir diversos efeitos adversos ao homem, porém não se pode calcular os níves seguros de trialometanos presentes na água de consumo humano, em virtude da inexistência de estudos quantitativos adequados (OPAS, 1987).

Porém a organização Mundial da Saúde recomenda um valor guia de $30 \mu \mathrm{g} \mathrm{L}^{-1}$ para o clorofórmio na água potável, para um consumo médio de 2 litros diários. Tal concentração deverá produzir menos de um caso adicional de câncer 
a cada 100.000 habitantes durante toda a vida (OPAS, 1987). Este resultado foi obtido aplicando-se um modelo estatístico em experimentos com ratos.

A real presença de compostos potencialmente carcinogênicos serviu como instrumento de pressão da sociedade, levando a EPA em 1979, a adotar um valor limite máximo permitido para os trialometanos totais de $100 \mu \mathrm{g} \mathrm{L}^{-1}$. Outros paises seguiram os Estados Unidos em relação à legislação, sendo adotados os limites de $350 \mu \mathrm{g} \mathrm{L}^{-1}$ no Canadá, $25 \mu \mathrm{g} \mathrm{L}^{-1}$, na Alemanha, $75 \mu \mathrm{g} \mathrm{L}^{-1}$ na Holanda e $10 \mu \mathrm{g} \mathrm{L}^{-1}$ na França (WORLD HEALTH ORGANIZATION, 1993).

No Brasil, somente a partir de 1990, pela da Portaria $N^{\circ} 36$, de 19 de Janeiro de 1990, Ministério da Saúde, ficou estabelecido uma concentração máxima de $100 \mu \mathrm{g} \mathrm{L}^{-1}$ para os THM (BRASIL, 2000). A legislação vigente ressalta ainda que este valor poderá ser revisto, em função dos estudos toxicológicos em andamento. Porém no ano de 2000, a EPA estabeleceu como valor final, uma concentração máxima de $80 \mu \mathrm{g} \mathrm{L}^{-1}$. 


\subsection{5 - Fatores que influenciam a formação de trialometanos}

\subsubsection{1 - Tempo de contato}

A reação para a formação de trialometanos em condições naturais não é instantânea. Estes compostos podem aparecer na água em menos de uma hora, mas, às vezes, surgem após dias. Isto ocorre porque vários fatores influenciam simultaneamente a velocidade de formação, não sendo possível, portanto, predizer o tempo de reação em função da complexidade das reações e da mistura de estruturas desconhecidas. É aceito o princípio de que quanto maior o tempo de contato maior será a probabilidade de formação de trialometanos (SANTOS, 1988). Assim é importante monitorar a concentração de trialometanos na ponta da rede mais distante da ETA, uma vez que os mesmos continuarão a se formar ao longo do percurso na distribuição.

\subsubsection{2 - Temperatura}

Como regra geral, aceita-se que quanto maior a temperatura maior será a probabilidade de formação de trialometanos (SANTOS, 1988). Em Cincinnati, Ohio (EUA) a variação na temperatura de inverno para o verão na água bruta, é tratada na faixa de $2^{\circ} \mathrm{C}$ a $28^{\circ} \mathrm{C}$ foi acompanhada por variações na concentração de clorofórmio de menos de $30 \mu \mathrm{g} \mathrm{L}^{-1}$ a mais de $200 \mu \mathrm{g} \mathrm{L}^{-1}$ na torneira do consumidor, quando se aplicou cloração na água bruta e tempo de contato de 3 a 4 dias. $\mathrm{Na}$ investigação feita por Stevens et al. (1997), clorando aquela água, a três temperaturas diferentes, ou seja $3^{\circ} \mathrm{C}, 25^{\circ} \mathrm{C}$ e $40^{\circ} \mathrm{C}$, ficou evidenciado que quanto maior a temperatura maior a formação de clorofórmio. Na Figura 27 encontra-se apresentado o gráfico sobre o efeito da temperatura na formação de THM. 


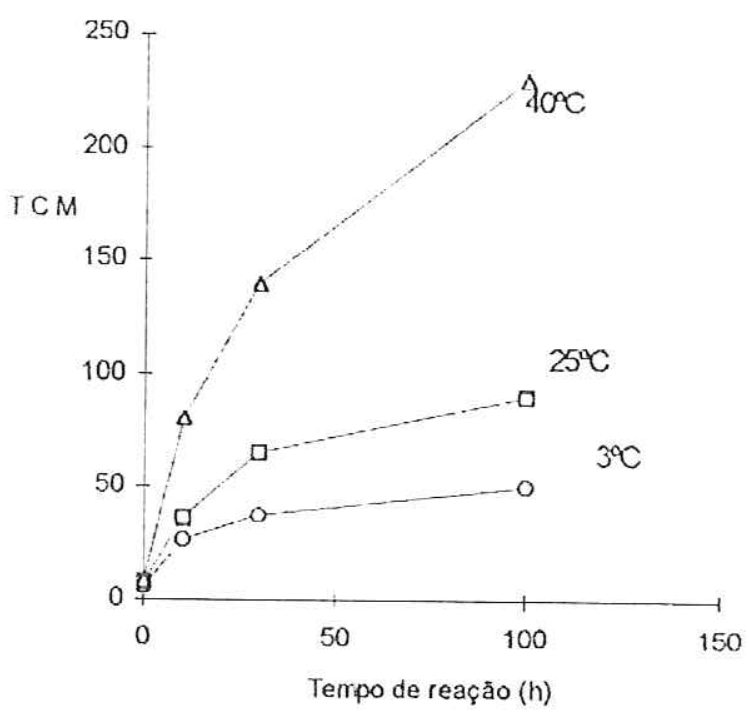

Figura 27 - Efeito da temperatura na formação de THM Stevens et al. (1997).

\subsubsection{3 - Efeito da concentração de brometo e iodeto na formação de subprodutos clorados}

A presença de brometos e iodetos facilita a formação de trialometanos, em cuja constituição apresenta o bromo e o iodo (SANTOS, 1988). Em águas superficiais brasileiras, a maior contribuição tem sido o bromodiclometano (16\%) e o dibromoclorometano (3\%). Os trialometanos iodados ainda não foram detectados (SANTOS, 1988)

\subsubsection{4 - Aumento do $\mathrm{pH}$}

Com o aumento do pH espera-se uma maior formação de trialometanos, em função da reação clássica "halofórmica" sendo catalisada por uma base Sanches et.al. (2003b). Symons et al. (1981) estudaram a influência do pH na formação de clorofórmio, e verificaram que no $\mathrm{pH} 11,5$ houve uma maior formação de clorofórmio do que no $\mathrm{pH}$ 6,5. Na Figura 28 encontra-se apresentado o gráfico referente ao estudo da influência do $\mathrm{pH}$ na formação de THM. 


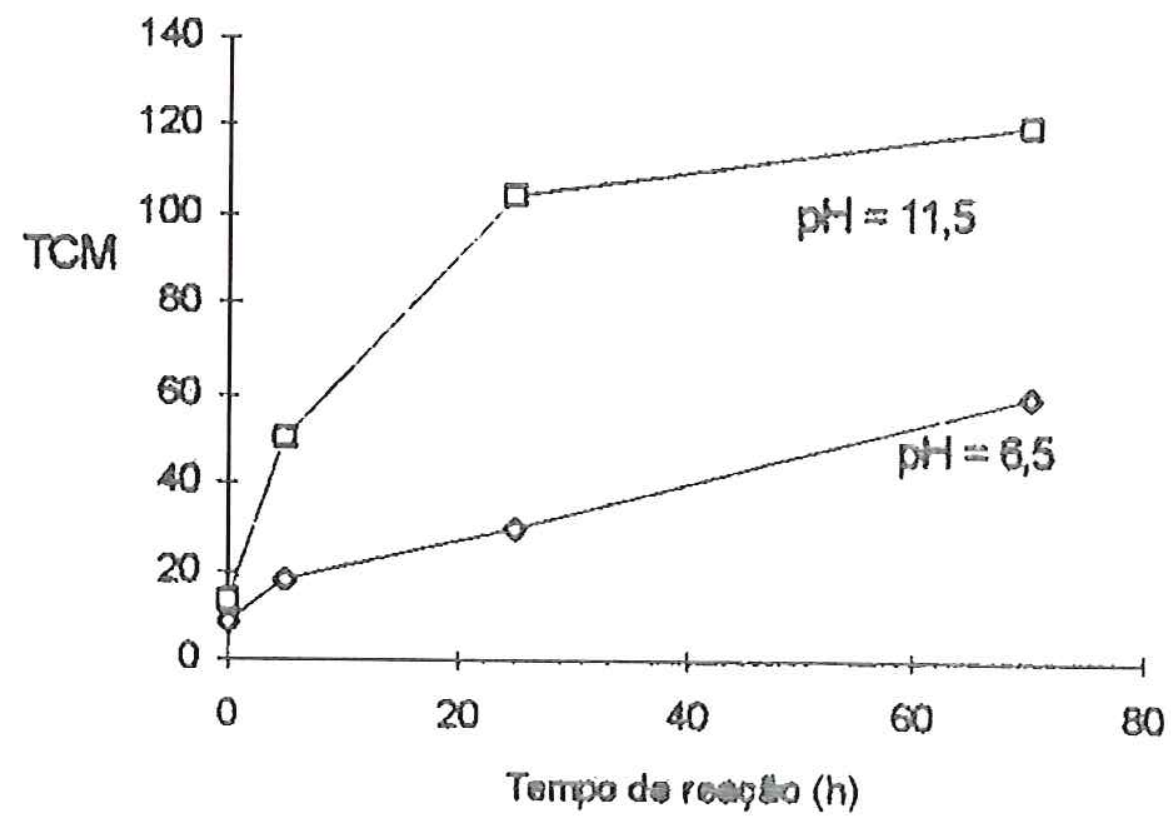

Figura 28 - Influência do pH na formação dos THM Symons et al. (1981).

4.1.5.5 - Efeito da concentração dos precursores na formação de subproduos clorados

Quanto maior a concentração de matéria orgânica maior será a formação de trialometanos Symons et al. (1981).

4.1.6 - Principais mecanismos propostos para a formação de cloróformio e outros trialometanos

Foram propostos vários mecanismos para a formação de clorofórmio e outros THMs durante a cloração. O mais simples envolve a reação de halofórmio na qual uma metilcetona é convertida na presença de base para ácido carboxílico e uma molécula THM. Evidências desse mecanismo ocorreram com a descoberta de que niveis de formação de THM aumentam com o pH. Isto apóia a hipótese de que a formação de THM pela reação de halofórmio é do tipo base-catalisada. $\mathrm{Na}$ 
Figura 29 encontra-se apresentado um possível mecanismo para formação de THM.

Reação de halofórmio:

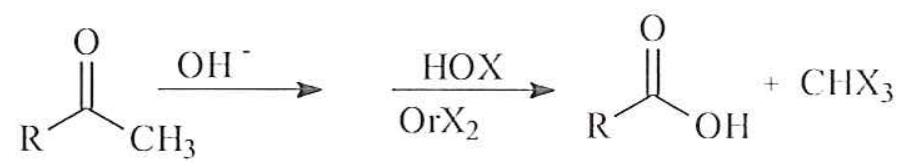

Figura 29: Possivel mecanismo de formação de THM

$\mathrm{Na}$ Figura 30 estão apresentadas algumas estruturas moleculares, comumente encontradas nos ácidos húmicos, e que são possivelmente responsáveis pela formação de clorofórmio.<smiles>[R]C(C)=O</smiles>

Acetila<smiles>[R1]c1c(O)cc(O)c([R1])c1[R1]</smiles>

Resorcinol<smiles>[R]OC(O)C(C)=O</smiles>

Beta-cetoéster<smiles>[R]C1C(=O)CC(=O)C([R1])([R3])C1([R3])[R]</smiles>

1,3- dicetona ciclohexano<smiles>[R]CC(=O)C=CC([R])=O</smiles>

Dicetona<smiles>[R]c1cnn(C)c1[R]</smiles>

Pirrol

Figura 30 - Prováveis estruturas moleculares responsáveis pela formação de clorofórmio (MACÊDO, 1997). 


\subsection{7 - Controle de trialometanos no processo de tratamento de água}

Uma vez que os trialometanos são formados na estação de tratamento de água pela reação do cloro com compostos orgânicos precursores presentes na água bruta. Três possiveis caminhos apontam para o controle destes subprodutos da desinfeção pelo cloro: a utilização de outros desinfetantes que não produzam trialometanos; a remoção dos compostos precursores antes de sua reação com o cloro para impedir a formação de trialometanos; e a remoção dos trialometanos após a sua formação.

\subsubsection{1 - Tratamento para reduzir a concentração dos precursores antes da desinfecção}

A experiência mais antiga de remoção dos precursores de THM na água prende-se ao uso do carvão ativado granular. O uso do carvão ativado tem demonstrado eficiência e reduz especificamente os precursores dos trialometanos, tornado possivel a desinfeç̧ão pelo cloro (DUSSERT, 1994; BATALHA, 1979).

O carvão ativado granular age como filtros grandes que são efetivos na remoção do material orgânico em águas. Quando novo, o carvão ativado adsorve a maioria dos precursores dos THM e produz uma água com concentrações completamente baixas de material orgânico Symons e Stevens (1976). Assim, os THM até aqui produtos orgânicos desconhecidos são significativamente reduzidos em águas cloradas que tem sido filtradas por carbono ativado granular.

Porém, há desvantagens, como o controle técnico da saturação do carvão ativado, pois ele só é eficiente quando está pouco saturado, com isso este material freqüentemente deve ser regenerado. $\mathrm{O}$ alto custo desta matéria prima e sua pequena disponibilidade no mercado torna inviável o seu uso (BATALHA, 1979). 


\subsubsection{2 - Carvão ativado em pó}

Os precursores dos THM são uma mistura de muitas substâncias químicas, e esta mistura varia conforme o corpo hídrico utilizado para a captação. O tratamento por adsorção dessas substâncias é mais dificil que o tratamento de produtos identificados individualmente.

As SH aquáticas são as mais relevantes dentre os precursores dos THM. As características dessas substâncias são influenciadas por numerosos fatores que alteram sua capacidade de adsorção, tais como distribuição da massa molecular, $\mathrm{pH}$, ions inorgânicos presentes, fonte dos precursores e frações relativas dos ácidos húmicos e fúlvicos. Essas variáveis influenciam as características físicas e químicas da solução e a própria superficie do carvão ativado, o que afeta a adsorção, mesmo de substâncias puras.

\subsubsection{2 - Coagulação}

A coagulação é um processo químico para a remoção de matéria orgânica presente em proporções substancial em água.

Para reduzir a quantidade de substâncias húmicas, precursores, de THM torna-se necessário ter um rígido controle do processo de coagulação, que ocorre por intermédio da eliminação da turbidez do efluentes das unidades de decantação. Com acompanhamento técnico do $\mathrm{pH}$, da quantidade de floculante e do auxiliar de coagulação a serem utilizados, obtém-se redução significante nos niveis da turbidez e das substâncias húmicas, mostrando-se a eficiência deste processo no controle da formação dos THM (DI BERNARDO, 1996; LIBÂNIO, 1997).

A coagulação é mais efetiva na remoção de frações humicas de grande massa molecular do que de moléculas orgânicas de baixa massa molecular em água. A coagulação, é seletiva na remoção de precursores que prontamente produzem THM como resultado da grande eficiência de remoção dos ácidos húmicos de grande peso molecular. Estudos realizados por (RANDTKE, 1981), 
demonstraram que a utilização de sulfato de alúminio como coagulante, proporcionou um aumento da capacidade de adsorção e da taxa de remoção dos ácidos húmicos e fúlvicos por carvão ativado granular.

\subsubsection{3 - Tratamento com carvão ativado granular para remoção de THM depois de formados}

A alternativa de remoção dos THM já formados significaria a construção de mais uma unidade numa estação de tratamento de água, existindo, entretanto, a possibilidade de aproveitamento das unidades já existentes. O uso do carvão ativado granular ativado é considerado, segundo (PERRY, 1983), o método mais eficiente na redução da concentração dos THM. Entretanto, a necessidade de regenerar o meio filtrante com freqüência, de modo a garantir a eficiência da remoção de material orgânico, é uma desvantagem do método.

\subsubsection{4 -Processos alternativos de desinfecção}

Os processos alternativos de desinfecção da água, que evitam a formação dos THM, são aqueles que não utilizam cloro livre, tais como: cloraminas (cloro combinado), dióxido de cloro, ozônio, permanganato de potássio, peróxido de hidrogênio, cloreto de bromo, bromo, iôdo, ion ferrato, alto $\mathrm{pH}$ e radiação utravioleta (LAUBUSCH, 1971; SANTOS, 1987). Destes, os mais utilizados são as cloraminas, o dióxido de cloro e a ozônio.

Embora o uso desses compostos na desinfecção ofereça a vantagem de não contribuir para a formação dos THM, outros subprodutos podem ser formados, conforme o teor de matéria orgânica presente na água (SANTOS, 1989). Esses subprodutos apresentam a mesma dificuldade de remoção que os THM, sendo que seus efeitos sobre a saúde não foram ainda completamente avaliados. cloritos e cloratos como subprodutos, bem como outras espécies aniônicas, cujo efeito à saúde é desconhecido. No capítulo 3 foram discutidas as vantagens e desvantagens da utilização de desinfetantes alternativos tais como cloraminas, 
díoxido de cloro, ozônio, peróxido de hidrogênio, ácido perácetico e radiação ultravioleta.

\subsection{8 -Técnica analítica utilizada para a identificação e quantificação dos trialometanos e outros subprodutos clorados}

\subsubsection{1 - Cromatografia Gasosa}

Entre as técnicas modernas de análises a cromatografia ocupa um lugar de destaque graças a sua facilidade em efetuar a separação, identificação e quantificação das espécies químicas.

A cromatografia é uma técnica que se baseia em características físicas e quimicas de separação dos componentes de uma mistura. Ela é constituida de duas fases: a móvel e a estacionaria, sendo que a móvel é encarregada de "carregar" a amostra sobre a fase estacionária, de modo que graças às propriedades diferentes dos componentes da mistura os componentes são separados (LANÇAS, 1997).

Na cromatografia gasosa a fase móvel é um gás, dai seu nome, sendo que a fase estacionária pode ser sólido ou líquida. A identificação dos componentes separados é feita comparando-se o tempo ou volume de retenção de um padrão com o da amostra; mas esta comparação não é conclusiva, pois na análise qualitativa, mais de uma substância pode apresentar o mesmo tempo de retenção, dependendo das condições da análise. Na análise quantitativa, o cromatógrafo pode estar acoplado a outros equipamentos de detecção mais seletiva como, por exemplo, o detector por espectrometria de massas. Assim, o composto pode ser identificado com mais certeza além do que, utilizando-se sistemas de detecção mais específicos, pode-se ter a identificação de alguns isômeros.

Para a determinação de trialometanos em água, é desejável um método de análise que apresente um limite de detecção abaixo de $1,0 \mu \mathrm{g} \mathrm{L}^{-1}$ (CARVALHO, 2003). Um método de análise bastante utilizado para a determinação de trialometanos e outros compostos organoclorados é o método da 
EPA 551(1990), para a determinação de subprodutos de desinfecção por cloração e solventes clorinados. A cromatografia gasosa com detector de captura de elétrons (ECD) é uma técnica versátil para a determinação dos trialometanos e outros subprodutos clorados.

O principio de funcionamento do detector ECD está baseado na captura de elétrons pelas moléculas da amostra, sendo que estes életrons são gerados por uma fonte radioativa, geralmente o Niquel-63, que emite partículas beta (elétrons), os quais colidem com as moléculas do gás de arraste, hidrogênio, e as ioniza. Os életrons gerados são atraídos para um anodo que se encontra $\mathrm{a}+90 \mathrm{~V} \mathrm{em}$ relação ao catodo, e geram uma corrente de $10^{-8}$. As moléculas eluidas da coluna, ao atingirem o detector, capturam estes elétrons livres e isso faz com que ocorra uma diminuição na corrente, e, consequentemente, ocasiona o aparecimento de um pico no cromatograma (LANÇAS, 1993). A intensidade do pico (área) que é apresentado no cromatograma, está relacionada à concentração dos analitos da amostras.

O ECD é um detector seletivo, sensivel, pode chegar a detectar picogramas de substância, e não é destrutivo. Tem sido empregado no estudo de haletos de alquila, hidrocarbonetos, cetonas e outras classes de compostos orgânicos. 


\section{2 - OBJETIVOS}

Os principais objetivos deste capitulo foram:

- Determinar e quantificar os trialometanos e outros subprodutos clorados formados durante a etapa de pré-oxidação da água contendo $\mathrm{SH}$ fracionadas com cloro e dióxido de cloro utilizando a cromatografia gasosa com detector de captura de elétrons como técnica analítica.

- Estudar a influência do tamanho molecular das substâncias húmicas na formação dos subprodutos clorados.

\section{3 - PARTE EXPERIMENTAL}

\subsection{1 - Ensaios de oxidação e determinação dos subprodutos clorados.}

Após determinada a demanda de cloro e dióxido de cloro que foram respectivamente de $7 \mathrm{mg} \mathrm{L}^{-1}$ e 1,0 $\mathrm{mg} \mathrm{L}^{-1}$, partiu-se para a realização dos ensaios de oxidação de uma água de cor aparente de 105 uH. Foram preparadas três águas, uma delas foi preparada adicionando-se as substâncias húmicas (SH) menor que $0,45 \mu \mathrm{m}$, e as outras duas com SH de tamanhos moleculares maior que 100 KDa e 30-100 KDa. Os ensaios de oxidação foram realizados em frascos de vidro âmbar de um litro de capacidade. Durante os ensaios, os frascos foram mantidos fechados e colocados em banho termostático a temperatura de $25^{\circ} \mathrm{C}$. Foram coletadas aliquotas de $10 \mathrm{~mL}$ das amostras de cada frasco, nos tempos de $4 ; 8 ; 16 ; 24 ; 36 ; 48 ; 72$ e 96 h. A cada amostra foi adicionado ácido ascórbico com a finalidade de inibir a reação. Posteriormente, em cada aliquota, foi adicionado um padrão interno (diclorometano) e extrairam os subprodutos clorados com a adiçao de $5 \mathrm{~mL}$ de éter-metil-terc-butirico. Separou-se a fase orgânica, e adicionou-se a esta o agente secante sulfato de sódio anidro. As amostras foram 
armazenadas em frascos especiais e conservadas a uma temperatura de $4^{\circ} \mathrm{C}$, para posteriores análises.

\subsection{2 -Análises cromatográficas}

As análises foram realizadas em um cromatógrafo à gás da marca Varian, modelo $3600 \mathrm{CX}$, equipado com detector de captura de elétrons (ECD), coluna capilar de sílica fundida J\&W-DB-1, $30 \mathrm{~m}$ de comprimento, 0,32 mm de diâmetro interno e filme de $5 \mu \mathrm{m}$ de espessura. As condições cromatográficas foram as mesmas utilizadas no item (3.2.5.1). Porém as curvas analiticas foram construídas com concentrações diferentes de 25; 50; 75; 100 e $150 \mu \mathrm{g} \mathrm{L}^{-1}$. Na Figura 31 encontra-se apresentada a curva analítica para o cloróformio.

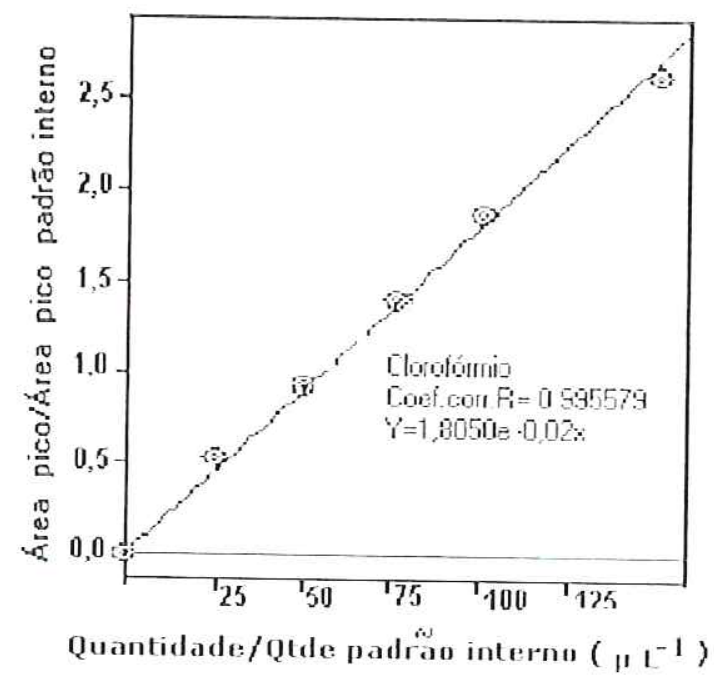

Figura 31 - Curva analítica para o clorofórmio. 


\section{4 - RESULTADOS E DISCUSSÃO}

\subsection{1 -Determinação dos subprodutos clorados formados durante a etapa de pré-oxidação da água contendo $\mathrm{SH}$, quando empregou-se o oxidante cloro}

Na reação inicial entre o cloro e a matéria orgância, grande parte do cloro que reage é incorporado dentro das moléculas orgânicas. Contudo, devido às condições da reação (tempo de reação, ou aumento da concentração de cloro), cada vez menos cloro que reage, é incorporado nas moléculas da matéria orgânica natural. Ao invés disto a maior parte, se não todo o cloro que reage nesse processo é incorporado na solução Li et al. (1988).

As reações entre o oxidante cloro e as substâncias húmicas, consistem em sucessivas hidrólises e halogenações. Sabe-se por exemplo que, o cloro reage com as estruturas moleculares responsáveis pela coloração da água, como cadeias aromáticas conjugadas com cetona ou outras cadeias aromáticas. Isso resulta no desaparecimento da coloração da água (EDUARDA, 2004).

Dentre as principais estruturas consideradas como capazes de formar os trialometanos, têm-se a estrutura do tipo resorcinol, a qual encontra-se ilustrada na Figura 32.

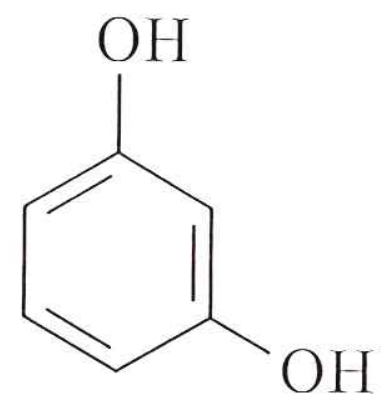

Figura 32 - Estrutura do tipo resorcinol.

Segundo (ROOK, 1979), a estrutura do tipo resorcinol presente nas SH, é a que mais favorece a formação dos THM. O mecanismo proposto por Rook et al. (1979), mostra que na estrutura do tipo resorcinol, o cloro ataca preferencilamente a posição entre duas hidroxilas, formando compostos 
1,3- ciclohexadiona, os quais são considerados efetivos na formação de clorofórmio. O mecanismo proposto por Rook et al. (1979) encontra-se apresentado na Figura 33.

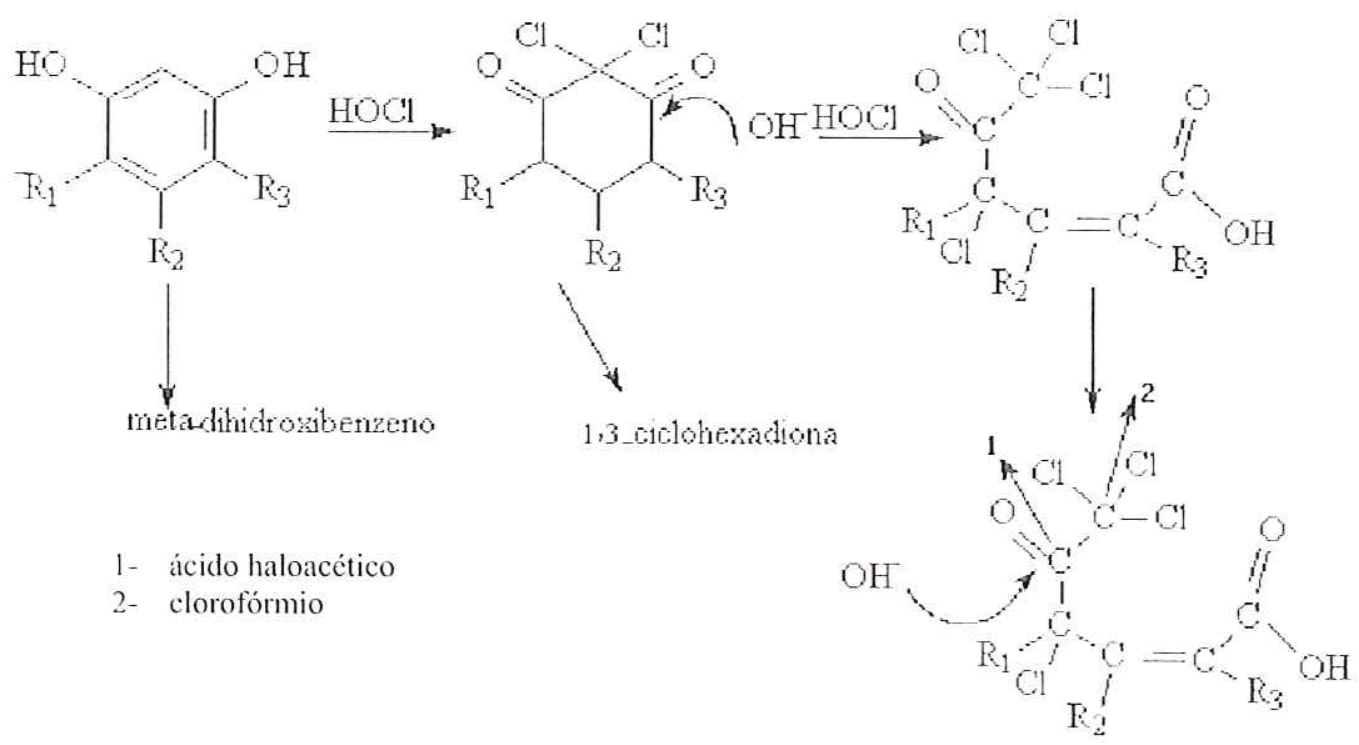

Figura 33 - Mecanismo de formação do clorofórmio, a partir da estrutura do tipo resorcinol.

Nas caracterizações das SH, realizadas por ressonância magnética nuclear de $\mathrm{C}^{13}$, acidez carboxílica, fenólica e total, infravermelho, ressonância paramagnética eletrônica, análise elementar e ultravioleta razão $E_{4} / E_{6}$ foram identificados grupos aromáticos, carboxilicos, cetônicos, quinonas dentre outros, os quais podem reagir com o cloro e formar os THM.

Sabe-se que em geral os compostos aromáticos são susceptiveis a reações, pois apresentam uma alta densidade eletrônica, o que proporciona uma alta reatividade com o cloro. Na Tabela 18 encontram-se os resultados referentes à formação de subprodutos clorados formados durante a oxidação da água contendo SH de tamanho molecular entre $0-0,45 \mu \mathrm{m}$ na qual foi utilizado $7,0 \mathrm{mg} \mathrm{L}$ 1 do oxidante cloro. E na Figura 34 está apresentado o gráfico referente a concentração de subprodutos da oxidação formados em função do tempo de reação com dados extraídos da Tabela 18. 
Tabela 18 - Subprodutos da oxidação formados durante a oxidação de uma água contendo SH filtrada em filtro $0,45 \mu \mathrm{m}$, utilizando-se a dosagem do oxidante cloro de $7,0 \mathrm{mg} \mathrm{L}^{-1}$.

\begin{tabular}{|c|c|c|c|c|}
\hline $\begin{array}{c}\text { Tempo da } \\
\text { reação } \\
(\mathbf{h})\end{array}$ & $\begin{array}{c}\text { Clorofórmio } \\
\left(\mu \mathbf{~ L}^{-1}\right)\end{array}$ & $\begin{array}{c}\text { Sicloro- } \\
\text { Acetonitrila } \\
\left(\mu \mathbf{~ L ~}^{-1}\right)\end{array}$ & $\begin{array}{c}\text { Bromodicloro- } \\
\text { Metano } \\
\left(\mu \mathbf{~ L}^{-1}\right)\end{array}$ & $\begin{array}{c}1,1,1- \\
\text { tricloro- } \\
\text { acetonitrila } \\
\left(\mu \mathbf{~ L}^{-1}\right)\end{array}$ \\
\hline \hline 4 & 2,32 & 1,07 & 1,17 & 0 \\
\hline 8 & 5,99 & 2,42 & 2,13 & 0,53 \\
\hline 12 & 6,10 & 2,48 & 1,88 & 0,60 \\
\hline 16 & 6,54 & 2,82 & 1,66 & 0,66 \\
\hline 24 & 7,54 & 3,12 & 2,32 & 0,72 \\
\hline 36 & 10,67 & 4,19 & 1,54 & 0,78 \\
\hline 48 & 11,18 & 5,11 & 1,67 & 0,84 \\
\hline 72 & 12,71 & 5,27 & 1,70 & 0,83 \\
\hline 96 & 14,78 & 5,49 & 1,45 & 0,80 \\
\hline
\end{tabular}

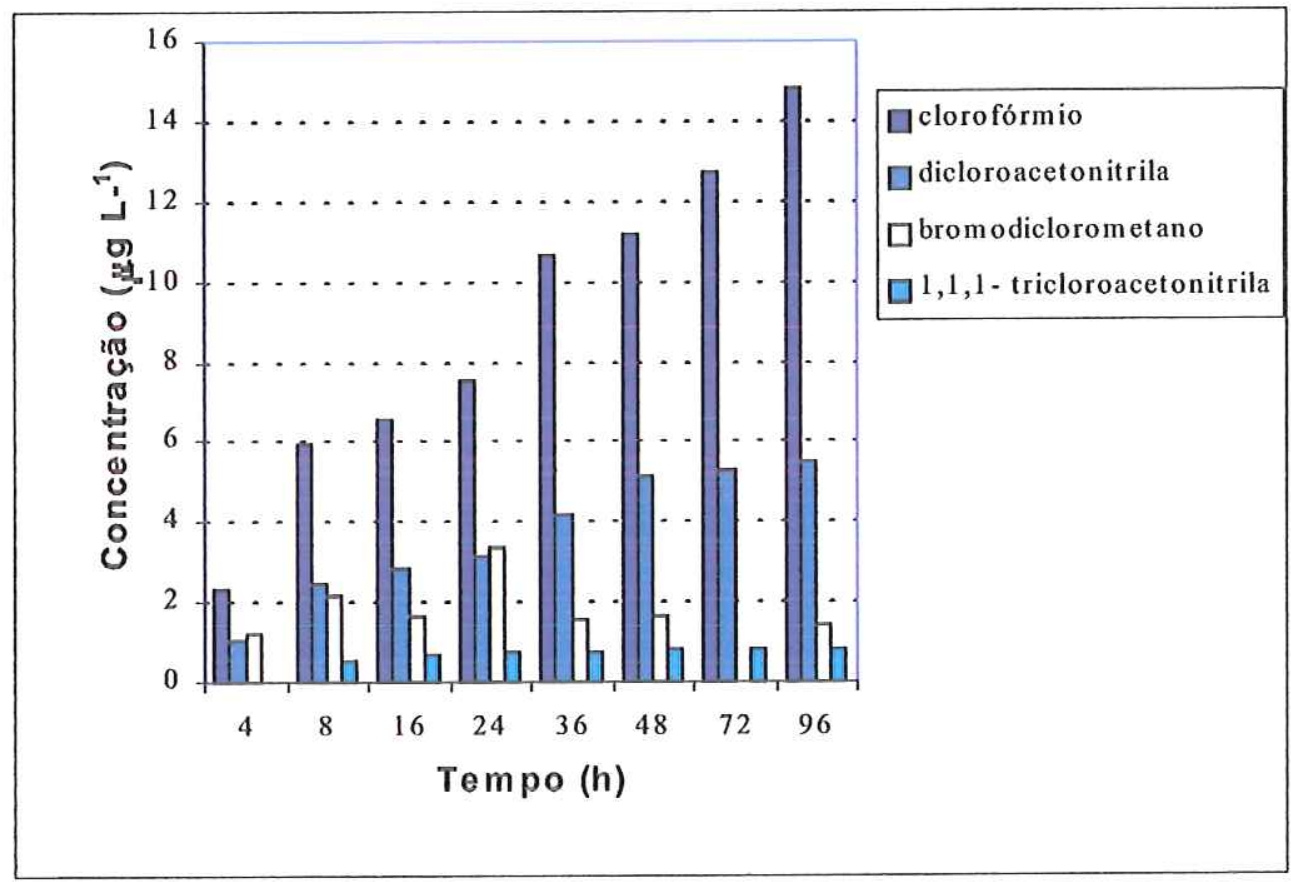

Figura 34 - Formação dos subprodutos da oxidação em função do tempo de reação, utilizando-se uma dosagem de $7,0 \mathrm{mg} \mathrm{L}^{-1}$ de cloro, cuja água foi preparada com SH filtrada em filtro $0,45 \mu \mathrm{m}$.

Analisando-se a Figura 34 e Tabela 18, observa-se que ocorreu a formação dos seguintes subprodutos da oxidação, clorofórmio, bromodiclorometano, 1,1,1 - 
triclorometano e dicloroacetonitrila. A formação do bromodiclorometano deve-se provavelmente à presença de traços do elemento bromo complexado às substâncias húmicas, visto que a água utilizada nos ensaios, do poço artesiano estava isenta dos íons brometo.

A formação dos THM puros e mistos contendo o elemento bromo em sua estrutura, como exemplo, o bromodiclorometano deve-se a oxidação dos íons brometos a bromo pelo uso do agente oxidante cloro, na presença de água contendo matéria orgância natural (TOMINAGA, 1998). Segundo Garcia-Villanova et al. (1997) o bromo, reage mais rapidamente que o cloro com os precursores para formar preferencialmente subprodutos bromados.

Segundo estudos realizados por (RIOS, 2004) a formação de subprodutos clorados já era esperada, quando utiliza-se o cloro na etapa de oxidação da água contendo $\mathrm{SH}$, no entanto a concentração de trialometanos totais formados durante o período de noventa e seis horas de reação, foi inferior ao limte máximo dos THM totais permitido. No Brasil, segundo a portaria $N^{0} 1469$, de 29 de dezembro de 2000, limitou a concentração de trialometanos em $100 \mu \mathrm{g} \mathrm{L}^{-1}$. Porém a Agência de Proteção Ambiental dos Estados Unidos da América (EPA, 2000), limitou um valor máximo para o total dos THM em $80 \mu \mathrm{g} \mathrm{L}^{-1}$. Segundo (SANTOS, 1989) os THM totais é a soma das concentrações dos quatro trialometanos encontrados em maior frequência, expressa em $\mu \mathrm{g} \mathrm{L}^{-1}$. Sendo que os quatro THM encontrados em concentrações significativas nas águas tratadas são, o clorofórmio, diclorobromometano, dibromoclorometano e bromofórmio (SANCHES, 2003). As concentrações deste THM são medidas conjuntamente, uma vez que eles são formados por reações similares, analisados por técnicas similares, cromatografia à gás,podem ter os mesmos efeitos tóxicos e são passiveis de controle em tratamento da água por técnicas similares. Analisando-se a Figura 33 observa-se que ocorreu a formação de traços de haloacetonitrilas ( dicloroacetonitrila, 1,1,1- tricloroacetonitra), e segundo a Organização Mundial da Saúde, a concentração máxima de haloacetonitrilas é de $60 \mu \mathrm{g} \mathrm{L}^{-1}$.

Analisando-se a Tabela 18 e a Figura 33 observa-se que o clorofórmio foi o produto majoritário. A reação para a formação dos THM não é instantânea, pois 
estes compostos podem aparecer na água em menos de uma hora, mas às vezes surgem após dias. Isto ocorre porque vários fatores influem simultaneamente na velocidade de reação, não sendo portanto, predizer o tempo da reação em função da complexibilidade das reações e da estrutura do precursor. $\dot{E}$ aceito o princípio de que quanto maior for o tempo de contato do oxidante com o precursor maior será a probabilidade de formação dos THM e outros subprodutos clorados. Analisando-se a Figura 33, nota-se que a concentração de clorofórmio, aumenta com o tempo de reação, estando de acordo com os estudos realizado por (Symons, 1981), o qual verificou este comportamento para o clorofórmio. A formação do clorofórmio deve-se principalmente a reação halofórmica, onde o ataque ocorre no grupo carboxílico Johnson e Jensen (1983). A National Academy is Safe Drinking Water Commitee levantou a hipótese de que a ingestão de água contendo clorofórmio na concentração de $20 \mu \mathrm{g} \mathrm{L}{ }^{-1}$, durante a vida, provoca um caso a mais de câncer que o normal em cada 3,333 habitantes, com nível de confiança de 95\% (ABDEL-RAHMAN, 1982). Existem evidências suficientes que o clorofórmio é carcinogênico para ratos e camundongos (BULL, 1982) sem contudo haver qualquer indicação para o homem. Todavia, pode-se considerar que apresente riscos para exposições humanas Tominaga e Midio (1999). Segundo a International Agency for Research on Cancer (IARC, 1991) as evidências à carcinogenicidade do clorofórmio para humanos são inadequadas, mas suficiente para animais. O bromodiclorometano, o dibromoclorometano e o bromofórmio estão enquadrados no grupo 3 onde as evidências para a carcinogenicidade são inadequadas para humanos e limitadas para animais Pitot III e Dragan (1996).

Nas Tabelas 19 e 20 encontram-se apresentados os resultados referentes à formação de subprodutos clorados, em função do tempo de reação, quando utilizou-se $7,0 \mathrm{mg} \mathrm{L}^{-1}$ do oxidante cloro. 
Tabela 19- Subprodutos da oxidação formados durante a pré- oxidação de uma água contendo SH de tamanho molecular entre 30-100KDa, utilizando-se 7,0 mg $\mathrm{L}^{-1}$ de cloro.

\begin{tabular}{|c|c|c|c|c|c|}
\hline $\begin{array}{c}\text { Tempo } \\
\text { da } \\
\text { reação } \\
(\mathrm{h})\end{array}$ & $\begin{array}{c}\text { Slorofórmio } \\
\left(\mu \mathrm{g} \mathrm{L}^{-1}\right)\end{array}$ & $\begin{array}{c}\text { Tricloro- } \\
\text { acetonitrila } \\
\left(\mu \mathrm{g} \mathrm{L}^{-1}\right)\end{array}$ & $\begin{array}{c}\text { Dicloro- } \\
\text { Acetonitrila } \\
\left(\mu \mathrm{g} \mathrm{L}^{-1}\right)\end{array}$ & $\begin{array}{c}\text { Bromodicloro } \\
- \text { metano } \\
\left(\mu \mathrm{g} \mathrm{L}^{-1}\right)\end{array}$ & $\begin{array}{c}\text { Bromo } \\
\text { cloro- } \\
\text { acetonitrila } \\
\left(\mu \mathrm{g} \mathrm{L}^{-1}\right)\end{array}$ \\
\hline 4 & 0,00 & 0,00 & 3,53 & 0,00 & 2,83 \\
\hline 8 & 0,00 & 0,00 & 6,49 & 0,00 & 2,89 \\
\hline 12 & 13,67 & 0,00 & 10,17 & 0,00 & 2,65 \\
\hline 16 & 19,25 & 1,16 & 18,63 & 0,00 & 4,26 \\
\hline 24 & 42,59 & 1,27 & 22,41 & 0,00 & 10,55 \\
\hline 36 & 54,42 & 2,18 & 29,18 & 0,75 & 9,71 \\
\hline 48 & 45,00 & 2,35 & 43,53 & 0,89 & 11,96 \\
\hline 72 & 64,38 & 2,47 & 37,17 & 0,86 & 6,35 \\
\hline 96 & 45,00 & 2,53 & 25,00 & 0,85 & 5,73 \\
\hline
\end{tabular}

Tabela 20 - Subprodutos da oxidação formados durante a pré-oxidação de uma água contendo SH de tamanho molecular maior que100 KDa, utilizando-se 7,0 mg $\mathrm{L}^{-1}$ do oxidante cloro.

\begin{tabular}{|c|c|c|c|}
\hline \multirow{2}{*}{$\begin{array}{c}\text { Tempo } \\
\text { de } \\
\text { reação } \\
(\mathrm{h})\end{array}$} & $\begin{array}{c}\text { Slorofórmio } \\
\left(\mu \mathrm{g} \mathrm{L}^{-1}\right)\end{array}$ & $\begin{array}{c}\text { Dicloro- } \\
\text { acetonitrila } \\
\left(\mu \mathrm{g} \mathrm{L}^{-1}\right)\end{array}$ & $\begin{array}{c}\text { Bromocloro- } \\
\text { Acetonitrila } \\
\left(\mu \mathrm{g} \mathrm{L}^{-1}\right)\end{array}$ \\
\hline 4 & 0,00 & 0,00 & 0,00 \\
\hline 8 & 6,34 & 3,00 & 0,00 \\
\hline 12 & 8,00 & 3,05 & 0,00 \\
\hline 16 & 8,14 & 2,96 & 0,00 \\
\hline 24 & 8,50 & 3,50 & 0,00 \\
\hline 36 & 12,17 & 4,42 & 1,03 \\
\hline 48 & 12,51 & 4,98 & 1,20 \\
\hline 72 & 13,83 & 4,45 & 1,84 \\
\hline 96 & 15,00 & 4,30 & 1,98 \\
\hline
\end{tabular}

Analisando-se as Tabelas 19 e 20, observa-se que o produto formado em maior concentração foi também o clorofórmio, e o aparecimento de novos subprodutos clorados como a dicloroacetonitrila e o bromocloroacetonitrila em relação aos resultados que estão apresentados na Tabela 18. O surgimento de 
espécies diferentes provavelmente deve-se a diferenças estruturas entre as diferentes frações.

Na Figura 29 descrita encontra-se apresentado um gráfico, no qual são comparadas as concentrações de clorofórmio formado em função dos diferentes tamanhos moleculares.

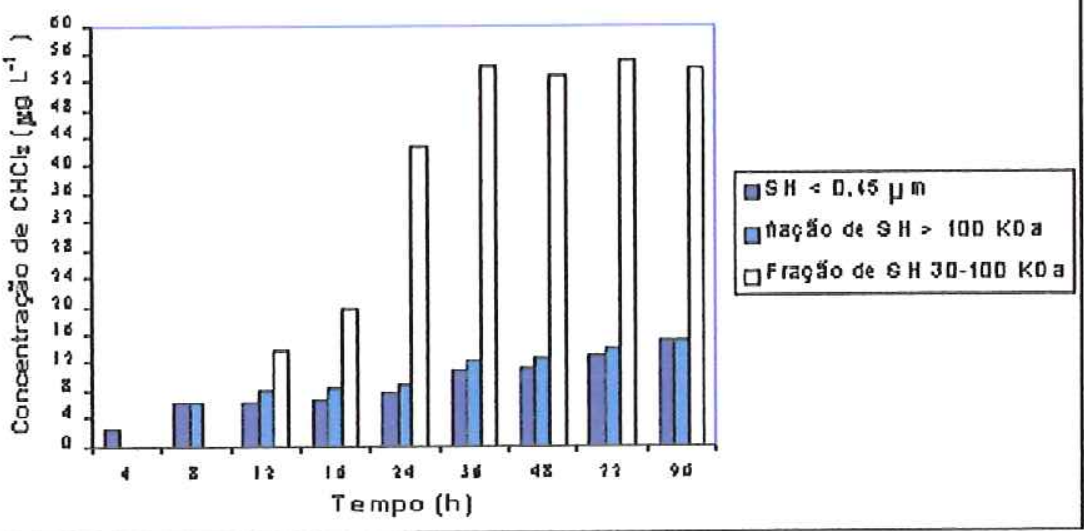

Figura 35 - Formação de clorofórmio em função do tamanho molecular das frações das SH utilizando-se a dosagem de $7,0 \mathrm{mg} \mathrm{L}^{-1}$ de cloro.

Observando-se a Figura 35, nota-se que ocorreu uma maior formação de clorofórmio nos ensaios de oxidação realizados com a fração de tamanho molecular no intervalo de 30-100 KDa. Este fato pode ser justificado, devido as diferenças estruturais entre as moléculas de diferentes tamanhos moleculares, pois nas caracterizações realizadas por ressonância magnética nuclear de $C^{! 3}$ por (CAMPOS, 2004), foi observado uma maior porcentagem de grupos oxigenados, tais como ésteres, grupos carboxílicos, grupos cetônicos. E nas caracterizações realizadas para determinar a acidez carboxílica e fenólica foi confirmado que a fração de tamanho molecular entre 30-100 KDa apresenta uma maior porcentagem destes grupos. Segundo o mecanismo proposto por (ROOK, 1979), apresentado na Figura 35, à formação de clorofórmio e outros subprodutos clorados deve-se a presença de grupos cetônicos e carboxílicos, nos quais segundo a reação halofórmica, ocorre um ataque preferencialmente nos grupos carboxílicos, os quais estão em maior porcentagem na fração de menor tamanho 
molecular 30-100 KDa. No item (4.1.6) foi descrito um provável mecanismo para a formação de trialometanos, o qual encontra-se apresentado na Figura 29.

\subsection{2 - Determinação de subprodutos clorados formados durante a etapa de pré-oxidação da água contendo SH com o oxidante dióxido de cloro.}

Segundo (CIOLA, 2002) o uso do dióxido de cloro é eficaz na redução da formação de THM e ácidos haloacéticos através da oxidação dos precursores.

Segundo (DI BERNARDO, 1995), os subprodutos clorados formados quando utiliza-se o oxidante dióxido de cloro, não foram estudados convenientemente, não sendo conhecido os impactos dos mesmos nos seres humanos, exceto estudos referentes a formação de clorito e clorato.

Segundo trabalhos realizados por Korn et al. (2002), a porcentagem média de conversão do dióxido de cloro em clorito e clorato são respectivamente de 68 e $9 \%$, em relação a massa. Nos ensaios realizados para a determinação dos subprodutos clorados formados durante a pré-oxidação de uma água preparada com SH de tamanho molecular menor do que 0,45 $\mu \mathrm{m}$, utilizando-se uma concentração de $1,0 \mathrm{mg} \mathrm{L}^{-1}$ de dióxido de cloro, durante o tempo da reação de noventa e seis horas, não observou-se a formação de THM e outros subprodutos clorados. Estes resultados estão de acordo com estudos realizados por Aieta e Berg (1986), no qual obtiveram resultados comparativos quando águas isentas de cloro foram preparadas com $5 \mathrm{mg} \mathrm{L}^{-1}$ de ácidos húmicos e a esta foram adicionadas $8,0 \mathrm{mg} \mathrm{L}^{-1}$ de cloro e de dióxido de cloro em ensaios separados. Nos resultados obtidos observaram que não houve a formação dos THM para a água tratada com dióxido de cloro, já para a água tratada com cloro observou-se a formação de clorofórmio.

Porém em estudos realizados por Chang et al. (2001), foi demonstrado que ocorreu a formação dos THM, ácidos haloacéticos, clorito e clorato, quando foram utilizadas concentrações de 1,0 a $10,0 \mathrm{mg} \mathrm{L}^{-1}$ de $\mathrm{ClO}_{2}$. Chang et al. (2001), sugeriu que ao usar maiores concentrações deste oxidante, aumenta-se a probabilidade de reações com os grupos $-\mathrm{OH}, \mathrm{O}-\mathrm{CH}_{3}$, os quais estão presentes na 
estrutura dos precursores orgânicos. Uma possivel razão para este fato, é que o dióxido de cloro quebra somente estruturas moleculares grandes em pequenas Chang et al. (2001). Ele mostrou que o percentual residual de ácidos húmicos decresce com o aumento da concentração de dióxido de cloro, entretanto a porcentagem residual de carbono orgânico dissolvido aumenta, o que indica o aumento da decomposição das moléculas que compõem os ácidos húmicos, pelo forte poder oxidante do dióxido de cloro.

Segundo Chang et al. (2001), vários grupos funcionais presentes nas estruturas das $\mathrm{SH}$, tais como, grupos hidroxil $(\mathrm{R}-\mathrm{OH})$, carbonil $(-\mathrm{CO})$, fenólicos e quinonas reagem iqualmente com o dióxido de cloro.

Em estudos realizados nas proximidades do $\mathrm{pH}$ neutro, para uma solução contendo ácidos fulvicos aquáticos e o oxidante dióxido de cloro $\left(\mathrm{ClO}_{2}\right)$, a reação é limitada e poucos produtos clorados são produzidos, o que vem a reforçar que o uso oxidante $\mathrm{ClO}_{2}$ é uma boa alternativa em relação ao uso do cloro (CARVALHO, 2004). O oxidante $\mathrm{ClO}_{2}$ reage primeiramente por reações de oxidação da matéria orgânica, resultando na formação de compostos orgânicos, volatéis ou não volatéis, nos quais os atómos de cloro têm sido incorporados. Já o oxidante cloro reage com as $\mathrm{SH}$ por oxidação e substituição eletrofilica, o que proporciona uma maior variedade de subprodutos clorados.

Nas Tabelas 21 e 22 encontram-se apresentados os resultados referentes a formação de subprodutos clorados em função do tempo de reação, quando utilizou-se $1 \mathrm{mg} \mathrm{L}^{-1}$ de $\mathrm{ClO}_{2}$, na pré-oxidação de águas preparadas com $\mathrm{SH}$ de tamanhos moleculares $<0,45 \mu \mathrm{m}$ e no intervalo de $30-100 \mathrm{KDa}$. 
Tabela 21 - Subprodutos clorados formados durante a pré- oxidação da água preparada com a fração da $\mathrm{SH}>100 \mathrm{KDa}$, utilizando-se a dosagem de $1,0 \mathrm{mg} \mathrm{L}^{-1}$ de dióxido de cloro.

\begin{tabular}{|c|c|c|c|c|}
\hline \multirow{2}{*}{$\begin{array}{c}\text { Tempo } \\
\text { de } \\
\text { reação } \\
\text { (h) }\end{array}$} & Clorofórmio & $\begin{array}{c}\text { Subprodutos clorados }\left(\mu \mathrm{g} \mathrm{L}^{-1}\right) \\
\text { acetonitrila }\end{array}$ & $\begin{array}{c}\text { Bromodicloro- } \\
\text { metano }\end{array}$ & $\begin{array}{c}\text { 1,1-dicloro- } \\
\text { propano }\end{array}$ \\
\hline 4 & 0,00 & 0,00 & 0,00 & 0,00 \\
\hline 8 & 0,00 & 0,00 & 0,00 & 0,00 \\
\hline 12 & 9,81 & 0,30 & 2,94 & 0,28 \\
\hline 16 & 10,50 & 0,43 & 1,96 & 0,40 \\
\hline 24 & 14,71 & 0,60 & 2,74 & 0,45 \\
\hline 36 & 14,00 & 0,65 & 2,50 & 0,57 \\
\hline 48 & 13,00 & 0,70 & 1,98 & 0,53 \\
\hline 72 & 12,30 & 0,65 & 2,31 & 0,49 \\
\hline 96 & 12,00 & 0,58 & 2,41 & 0,53 \\
\hline
\end{tabular}

Tabela 22 - Determinação de subprodutos da oxidação formados durante a etapa de pré-oxidação da água contendo fração da SH de tamanho molecular entre $30-100 \mathrm{KDa}$, utilizando-se a dosagem de 1,0 $\mathrm{mg} \mathrm{L}^{-1}$ de dióxido de cloro.

\begin{tabular}{|c|c|c|c|c|}
\hline $\begin{array}{c}\text { Tempo } \\
\text { de } \\
\text { reação } \\
(\mathrm{h})\end{array}$ & $\begin{array}{c}\text { Clorofórmio } \\
\left(\mu \mathrm{g} \mathrm{L}^{-1}\right)\end{array}$ & $\begin{array}{c}\text { Subloro- } \\
\text { Acetonitrila } \\
\left(\mu \mathrm{g} \mathrm{L}^{-1}\right)\end{array}$ & $\begin{array}{c}\text { Bromodicloro- } \\
\text { Metano } \\
\left(\mu \mathrm{g} \mathrm{L}^{-1}\right)\end{array}$ & $\begin{array}{c}\text { 1,1-dicloro- } \\
\text { propano } \\
\left(\mu \mathrm{g} \mathrm{L}^{-1}\right)\end{array}$ \\
\hline 4 & 0,00 & 0,00 & 0,00 & 0,00 \\
\hline 8 & 0,00 & 0,00 & 0,00 & 0,00 \\
\hline 12 & 11,70 & 0,64 & 3,46 & 1,00 \\
\hline 16 & 12,10 & 0,70 & 3,24 & 1,03 \\
\hline 24 & 14,89 & 1,00 & 4,00 & 0,91 \\
\hline 36 & 15,00 & 1,44 & 3,50 & 0,95 \\
\hline 48 & 14,30 & 1,94 & 4,50 & 1,30 \\
\hline 72 & 14,50 & 1,71 & 4,23 & 1,40 \\
\hline 96 & 15,00 & 1,60 & 4,70 & 1,30 \\
\hline
\end{tabular}

Analisando-se os resultados apresentados nas Tabelas 21 e 22, observa-se que ocorreu a formação dos seguintes subprodutos clorados, clorofórmio, tricloroacetonitrilas, bromodiclorometano e 1,1 - diclorometano.

O produto majoritário para ambas as frações foi o cloróformio. Em nenhum dos resultados a soma total dos trialometanos e cloropicrinas excedeu o valor máximo permitido que são respectivamente de 100 e $60 \mathrm{~g} \mathrm{~L} \mathrm{~L}^{-1}$. 
Nas Tabelas 21 e 22 encontram-se os resultados referentes as concentrações de clorofórmio, formados em função dos diferentes tamanhos moleculares, quando utilizou-se o oxidante dióxido de cloro.

Analisando-se as Tabelas 21 e 22 observa-se que ocorre uma maior formação de clorofórmio, nos ensaios realizados com a água preparada com a fração da SH de tamanho molecular no intervalo de 30 -100 KDa.

A maior formação de subprodutos clorados para esta fração ocorre por esta possuir uma maior porcentagem de grupos oxigenados, os quais foram constatados durante as caracterizações das frações por RMN, acidez carboxilica e fenólica, analise elementar. Também foi verificado através de EPR que esta fração apresentou um maior número de grupos quinonas.

Segundo Chang et al. (2001), vários grupos funcionais presentes nas estruturas das $\mathrm{SH}$, tais como, grupos hidroxil (R-OH), carbonil (-CO), fenólicos e quinonas reagem igualmente com o dióxido de cloro, sendo estes grupos mais reativos e tendo-se maior porcentagem destes na fração de menor tamanho molecular é de se esperar uma maior concentração dos subprodutos clorados, nos ensaio em que a água foi preparada com a fração 30 -100 KDa. 


\section{5 - CONCLUSÕES}

Nos ensaios de oxidação da água contendo diferentes frações de SH, com o oxidante cloro e dióxido, observou-se que o clorofórmio foi o subproduto formado em maior concentração, e que nos ensaios de oxidação da água com o cloro ocorreu uma maior variedade de espécies de subprodutos da oxidação em relação a oxidação realizada com o oxidante dióxido de cloro. Na oxidação da água contendo $\mathrm{SH}$ com o cloro, a concentração do clorofórmio formado aumentou com o tempo de reação.

Observou-se que ocorre a influência do tamanho molecular das $\mathrm{SH}$ na formação do clorofórmio, visto que a água preparada com SH de menor tamanho molecular (30-100 KDa), proporcionou uma maior concentração de clorofórmio, nos ensaios realizados com os oxidantes cloro e dióxido de cloro.

Com respeito ao oxidante alternativo, o dióxido de cloro, mostra-se bastante promissor em relação ao cloro, por produzir menos subprodutos da oxidação. 


\section{CAPÍTULO - 5}

\section{Conclusões gerais e propostas de trabalhos futuros}

\section{1 - CONCLUSÕES GERAIS}

De acordo com os resultados obtidos neste trabalho, conclui-se que:

- Torna-se necessário a utilização de diferentes técnicas para o estudo de materiais tão complexos e heterogêneos como as $\mathrm{SH}$ e demonstram as potencialidades destas técnicas no estudo da reatividade destas substâncias.

- As caracterizações realizadas por infravermelho (IV), acidez carboxílica, fenólica e total, análise elementar, espectrofotometria na região do visivel, ressonância paramagnética eletrônica (EPR), ressonância magnética nuclear (RMN de $\mathrm{C}^{13} \mathrm{CP} / \mathrm{MAS}$ ), demonstraram que a amostra de substâncias húmicas que possui todas as frações (filtrada $0,45 \mu \mathrm{m}$ ) encontra-se mais condensada, ou seja possui uma maior porcentagem de grupos aromáticos em relação as frações de tamanho molecular maior do que $100 \mathrm{KDa}$ e as SH de tamanho molecular entre 30 - 100 KDa. Na fração das SH de tamanho molecular entre 30 - 100 KDa, verificou-se uma maior porcentagem relativa de grupos como oxigênio ligado, tais como ésteres, cetonas, álccois, éteres, carboxilicos e oxigênios ligados em cadeias alifáticos (grupo metoxi).

- Nos ensaios de oxidação da água contendo SH, com o oxidante cloro e dióxido, observou-se que o clorofórmio foi o subproduto formado em maior concentração, e com relação a cor da água, observou-se que o oxidante dióxido de cloro possui maior ação oxidante sobre a matéria orgânica do que o cloro, pois proporcionou uma maior redução da cor da água. O oxidante cloro propiciou uma maior formação de espécies de subprodutos clorados em relação a oxidação realizada com o dióxido de cloro. Também verificou-se que na oxidação da água de estudo com o cloro, a concentração do clorofórmio formado aumentou com o tempo de reação. 
- O tamanho molecular das SH influencia na formação do clorofórmio, visto que a água de estudo preparada com SH de tamanho molecular 30-100 KDa, propiciou uma maior concentração de clorofórmio.

- Com respeito ao oxidante alternativo, o dióxido de cloro, mostra-se bastante promissor em relação ao cloro, por produzir menos subprodutos clorados nas dosagens de cloro e dióxido de cloro utilizadas.

\section{2 - PROPOSTAS PARA TRABALHOS FUTUROS}

Realizar ensaios para determinação de ácidos haloacéticos e trialometanos originados durante a oxidação da água contendo frações de diferentes tamanhos moleculares de substâncias húmicas aquáticas com os oxidantes cloro e dióxido de cloro.

Realizar o monitoramento de ácidos haloacéticos e trialometanos, nos efluentes das industrias de papel e celulose, visto que no branqueamento da polpa de celulose, utiliza-se os oxidantes cloro e dióxido de cloro.

Desenvolvimento e validação de metodologia para determinação de ácidos haloacéticos por cromatografia líquida de alta eficiência. 


\section{CAPITULO - 6}

\section{REFERÊNCIAS BIBLIOGRÁFICAS}

ABDEL-RAHMAN, M.S. (1982). The presence of trihalomethanes in soft drinks. Journal of Apllied Toxicology, v.2, n.3, p.165-166.

Agência Nacional de Vigilância Sanitária (ANVISA); Resolução RE n.899, de 29/05/2003.

AZEVEDO NETTO, J. M. (1987). Técnica de abastecimento e tratamento de água. 3.ed., São Paulo: Cetesb, 317p.

BACAN, N. (1979). Química Analitica quantitativa elementar. São Paulo: Edgard Blucher, 183p.

BARROS, M.C.P.; PAULA, J.R.; REZENDE, M.O.O. (1994). Caracterização físicoquímica do ácido húmico de solo da ilha de Cananéia e de sua interação com Fe(III), Cu(II) e Cd(II). Química Nova, v.17, n.5, p.376- 380.

BATALHA, B.L. A presença de clorofórmio e outros trihalometanos na água de consumo humano. In: CONGRESSO BRASILEIRO DE ENGENHARIA SANITÁRIA AMBIENTAL, 10, 1979, Manaus. Anais. ...Manaus: associação Brasileira de Engenharia Sanitária e Ambiental - ABES, 1979. p.1-45.

BELLAR, T.A, LICHTENBERG, J.J., KRONER, R.C. (1974). The ocurrence of organohalides in chlorinated drinking waters. Journal American Water Works Assocition, Denver, v.66, n.12, p.703-706.

BLATCHLEY III, E.R., XIE, Y. (1995). Disinfection and antimicrobial processes Water Environmental Research, v.66, n.4, p.361-368.

BLOEMEN, H.J.Th., BURN, J. (1993) Chemistry and analysis of volatile organic compounds in the environment. London: Chapman \& Hall. 290p.

BRASIL. Leis, decretos, etc...Portaria n.36, de 19 de janeiro de 1990, Estabelece os procedimentos e responsabilidades relativos ao controle e vigilância da qualidade da água para consumo humano e seu padrão de potabilidade e dá outras providências Diário Oficial da União da República Federativa do Brasil, Brasilia DF, n.14E, 19 jan. 1990. Secção 1.

BRASIL. Leis, decretos, etc ... Portaria n 1469, 29 de dezembro de 2000, Estabelece os procedimentos e responsabilidades relativos ao controle e vigilância da qualidade da água para o consumo humano e seu padrão de potabilidade e dá outras providências Diário Oficial da República Federativa do Brasil, Brasilia, n.14E, 19 de jan. 2001. Secção 1.

BRESSOLE, F., BROMET-PETIT, M., AUDRAN, M. (1996). Validation of liquid chromatographic and gas chromatographic methods: applications to pharmacokinetics. Journal of Chromatography B, v.686, p.3-10. 
BRITO,.N.M., AMARANTE Jr., O.P., POLESE, L., RIBEIRO, M.L.R. (2003). Validação de métodos analíticos: Estratégia e discussão. Pesticidas: Revista de ecotoxicologia, v.13, p.129-146, jan./dezembro.

BUL, R.J. (1982). Health effects of drinking water disinfectants and disinfectant byproducts. Environ. Sci. Technol, v.16, n.10, p.554 ${ }^{\mathrm{A}}-559^{\mathrm{a}}$

CALACE, N.; DE PAOLIS, F.; MINNITI, F.; PETRONIO, B.M. (1998). Purification of soluble fulvic low concentration by a diafiltration techinique. Talanta, v.47, p.803809.

CAMPOS de, S. X. influência das substâncias húmicas de diferentes massas molares na coagulação, floculação e sedimentação no tratamento de água. 122p. Tese (Doutorado). Escola de Engenharia de São Carlos, Universidade de São Paulo, São Carlos.

CARVALHO, E.R. Estudos da formação de trihalometanos a partir de substâncias húmicas aquáticas tratadas com cloro e dióxido de cloro.192p. Tese (Doutorado) - Interunidades Ciência e Engenharia de Materiais da Universidade de São Paulo, Universidade de São Paulo, São Carlos. 2003.

CASS, B.Q., DEGANI, G. (2001). Desenvolvimento de métodos por HPLC: fundamentos, estratégias e validação. São Carlos: EduFSCar, Série Apontamentos. /Apostila/.

CAUSON, R. (1997). Validation of chromatographic methods in biomedical analsisViewpoint and discussion. Journal of Chromatographic, v.689, p.175-180.

CHAMBERS, C.W. (1956). A procedure for evaluating the efficiency of bactericida agents. Journal Milk Food Tecnology, v.19, n.17, p.183-187.

CHANG, CHEN-YU.; HSIEH, YUNG-HSU.; LIN, YU-MIN.; HU, PO-YU.; LIU, CHINCHUAN.; WANG, KUO-HUA. (2001). The organic precursors affecting the formation of disinfection by-products with chlorine dioxide. Chemosphere, v.44, p.1153- 1158.

CHASIN, A.A.M., CHASIN, M., SALVADORI, M.C. (1994). Validação de métodos cromatográficos em análises toxicológicas. Rev. Farm. Bioquim. Univ São Paulo, São Paulo, v. 30, n.2, p.49-53.

CHEN, Y.; SENESI, N.; SCHINITZER, M. (1977). Information provided on humic substances by $E_{4} / E_{6}$ ratios. Soil Science Society of Ameica Journal, v.41, p.352358.

CHEN, J.; GU, B.; LEBOEUF, E. J.; PAN, H.; DAI, S.(2002). Spectroscopic characterization of the structural and functional properties of natural organic matter fractions. Chemosphere, v.48, p.59-68. 
CLAPP, C.E.; HAYES, M.H.B.; SWIFT. (1993). Organic substances in soil and water natural constituents and their influences on contaminant behaviour. Cambridge: Royal Socity of Chemystry,

CONGRESSO BRASILEIRO DE ENGENHARIA SANITÁRIA E AMBIENTAL, 11,1981, Fortaleza. Anais. Fortaleza: Associação Brasileira de Engenharia Sanitária e Ambiental - ABES, 1981. P.2-29.

DAVIS, W.M.; JOHNSTON, C.T.; DELFINO, J.J.; PORTER, J.E. (1999). Quantitative Fourier transform infrared spectroscopic investigation of humic substance functional group composition. Chemosphere, v.38, n.12, p.2913-2928.

DI BERNARDO, L. (1995). Algas e suas influências na qualidade de águas e tecnologias de tratamento. Rio de Janeiro: ABES.

DI BERNARDO, L., CONCEIÇÃO, R.A.P., DI BERNARDO, A.S. (1996). Efeito da acidez na solução de sulfato de alumínio na eficiência da coagulação. Engenharia Sanitária e Ambiental, v.1, n.4, p.144-151.

DICK, D.; BURBA, P.; HERZOG, H. (1998) Resumos do 9 th International Humic Substances Society, Livro de resumos, p.75.

DUSSERT, B.W., STONE, G.R.V. (1994). The biological activated carbon process for water purification. Water/Engineering \& Management, v.5, p.32-35.

EPA (Environmental Protection Agency). (1999). Alternative disinfectants and oxidants guidance manual. EPA-815-R-99-014. April.

FALONE, Z.S. (2002). Estudo da interação de explosivos com substâncias húmicas de diferentes procedências. 104p. Dissertação (Mestrado). Instituto de Quimica de São Carlos, Universidade de São Paulo, São Carlos.

FALONE, S.Z.; AMARANTE JR, O.P.; VIEIRA, E.M. (2004). Pesquisas em meio ambiente: subsideos para a gestão de politicas Públicas. In: Interação do explosivo HMX com turfa na presença e na ausência de matéria orgânica. São Carlos: Rima, p.155 - 164.

FELBECK, G.T. JR. (1965). Strtural chemistry of soil humic substances. Adv.Agron, v.17, p.327-368.

FICHER, F.; SHAHRADER, H. (1921). The origin and chemical structure of coal. Brennstoff Chemical, v.2, p.37-45.

FLAIG, W. (1964). Chemische Untersuchugen na humin-stoffen. Chemie, v.4, p.253-365. 
FRANCOTTE, E., DAVATAZ, A., DAVATAZ, A., RICHERT, P. (1996).

Development and validation of chiral high-performance liquid chromatographic methods for the quantitation of valsartan and of the tosylate of valinebenzyl ester. Journal of Chromatographic B, v.686, p.77-83.

FUCCHS, W. (1931). Di.Chemie.der. Kohle. Berlim: Springer.

FUKUSHIMA, M.; TANAKA, S.; NAKAMURA, H.; ITO, S. (1996). Acid-base characterization of molecular weight fractionated humic humic acid. Talanta, v.43, p.383-390.

GARCIA-VILLANOVA, R.J.; GARCIA, C.; GOMEZ, J.A.; GARCIA, M.P.; ARDANUY, R. (1997). Formation, evolution and a modeling of trihalomethanes in the drinking water of a town: I at the municipal treatment utilities. Water Research, v.31, n.6, p.1299-1308.

GRAY, N.F. (1994). Calidad del agua potable. Zaragosa: Acribia.

GREEN, J.M. (1996). A practial Guide to Analytical Method Validation. Anal. Chem. News \& Features, p.305A-309A.

GRIFFITH, S.M.; SCHINITZER, M. (1975). Analytical characteristics of humic and fulvic acids extracted from tropical volcanic soils. Soil Science Society of America Proceedings, v.39, p.861- 867.

GUERRA, J. G. M.; SANTOS, G. A. (1999) Métodos Químicos e Físicos. Fundamentos da Matéria Orgânica do Solo Ecossistemas Tropicais e Subtropicais. Porto Alegre: Gênesis.

Guidance for Industry. (2001). Bioanalytical Method Validation. US Department of Health na Human services; Food and Drug Administration, Center of Drug Evaluation and research (CDER), Center of Veterinary Medicine (CVM), maio. Bp.

HOBSON, R. P.; PAGE, H. J. (1932). Carbon and nitrogen cycles in the soil. The nature of organic nitrogen compounds of the soil: humic nitrogen. Journal. Agronomic Science, v.22, p.497-515.

IBARRA, J.V.; JUAN, R. (1985). Structural changes in humic acids during the coalification process. Fuel, v.64, p.650- 656.

Instituto Nacional de Metrologia, Normalização e Qualidade Insdustrial (INMETRO); Orientações sobre validação de métodos de ensaios, DOQ-CGCRE008, 2003.

Internacional Conference on Harmonization (ICH), Q2A: Validation of Analytical Procedures: Definitions and terminology, Q2A (CPMP/ICH/381/95), 1995.

Internacional Conference on Harmonization (ICH), Q2b: Validation of Analytical Procedures: Methodology, US FDA Federal Register, v.62, maio 1997, p.27463. 
JANOS, P.; TOKAROVA, V. ( 2002). Characterization of coal-derived humic substances with the aid or low-pressure gel permeation chromatography. Fuel, v.81, p.1025-1031.

JEZIERSKI, A.; CZECHOWSKI, F.; JERZYKIEWICZ, M.; DROZD, J. (2000). EPR investigations of structure of humic acids from compost, soil, peat and soft brown coal upon oxidation and metal uptake. Applied Magnetic Resonance. v.18, p. $127-$ 136.

JOHNSON, J.D.; JENSEN, J. (1983). Thm and toxicity formation routes, rates and precursors. In: Awwa seminar proceedings - strategies for the control of trihalomethanes, 1983, Las Vegas. Proceedings. Las Vegas: American Waters Works Association - AWWA, p.1- 21.

KENWORTHY, I.P.; HAYES, M. H. B. (1997). Investigations of some structural properties of humic substances by fluorescence quenching. Cambridge:. The Royal Society of Chemistry:

KHAN, S. U.; SHINITZER, M. (1980) Journal of soil Science, v.49, p.2302.

KLEINHEMPEL, D. (1970). Beziehungen einiger humintoffkennzahlen zum ertrag auf schwarzerdestandorten. Albrecht-Thaer-Archiv. Bd. v.14, p.1.

KONONOVA, M. M. (1966). Soil Organic Matter. Oxford: Pergamon Press.

KORN, C.; ANDREWS, R. C.; ESCOBAR, M. D. (2002). Development of chlorine dioxide-related by-product models for drinking water treatment. Water Research, v.36, p.330-342.

LANÇAS, F.M. (1993). Cromatografia em fase gasosa. São Carlos: acta Brasil. $254 p$.

LAUBUSCH, E.J. (1971). Chlorination and other disinfection processes. In: Water Quality and Treatment: A Handbook of Public Water Supplies (American Water Works Assocciation), New York: McGraw-Hill Book Company. P.158-224.

LEITE, F. (2002). Validação em análise quimica. Campinas: Editora Átomo.

LI, C.W.; KORSHIN, G.V.; BENJAMIM, M.M. (1998). Monitoring formation of disinfection by-products with differential UV spectroscopy. JOURNAL AMERICAN WATER WORK ASSOCIATION, V.90, N.8, P.88-100.

LIBÂNIO, M. (1997). A otimização do processo de coagulação no controle dos subprodutos da desinfecção de águas de abastecimento. Revista de Engenharia Sanitária é Ambiental, v.2, n.1, p.175.

LONG, G.L., WINEFORDNER, J.D. (1983) Limit of detection: a closer look at the IUPAC definition. Analytical chemistry, v.55, n.7, p.712A-724A . 
LU, X.Q.; HANNA,J.V.; JOHNSON, W.D. (2000). Source indicators of humic substances na elemental composition, solid state ${ }^{13} \mathrm{C}$ CP/MAS NMR and PyGC/MS study. Appl. Geochem., v.15, n.7, p.1019- 1033.

MACÊDO, J.A. B. (1997) Determinação de trihalometanos em águas de abastecimento público e de indústria de alimentos. 90p. Tese (Doutorado) Ciência e Tecnologia de Alimentos, Universidade Federal de Viçosa, Viçosa.

MALCOM, R. L. (1990). The uniqueness of humic substances in each of soil, stream and marine environments. Analytica Chimica Acta, v.232, p.19-30.

MAROTO, A. ; RIU, J.; BOQUÉ, R.; RIUS, F.X. (1999). Estimating uncertainties of analytical results using informations from the validation process. Anal. Chim. Acta., v.391, p.159- 171.

MARTIN-NETO, L.; ROSELL, R.; SPOSITO, G. (1998). Correlation of spectroscopic indicators of humification with mean annual rainfall along a temperate grassland climosequence. Geoderma, v.81, p.305- 311.

MEYER, S.T. (1994). O uso de cloro na desinfecção de águas, a formação de trihalometanos e os riscos potenciais à saúde púlica. Caderno de Saúde Púlica, v.10, n.1, p.99-110, Janeiro/Março.

MUTTAMARA, S.; SALES, C. I.; GAZALI, Z. (1995). The formation of trihalometanos from chemical disinfectants and humic substances in drinking water. Water Supply, v.13, n.2, p.105-117.

OLIVER, B.G. (1989). Analysis of volatile halogenated and purgeable organics. In: AFGHAN, B.K., CHAU, A.S.Y., EDS. Analysis of trace organics in the aquatic environment. Boca raton: CRC Press, p.1-29.

ORANIZACION PANAMERICANA DE LA SALUD (OPAS). 1987. Guias para lacalidad del agua potable. Washington, v.2, 350p.

PERRY, R. (1982). Aspects of the chemistry and analysis of substances of concern in the water cycle. In: POLLUTION: causes, effects and control. London: Roy M. Harrison. P.35-50.

PICCOLO, A; NARDI, S.; CONCHERI, G.(1996). Macromolecular changes of humic substances as revealed by size-exclusion chromatography. Journal Organic Soil Science, v.47, p.319.

PICCOLO, A.; CONTE, P. (2000). Molecular size of humic substances. Supramolecular associations versus macromolecular polymers. Advances in Environmental Research, v.3, p.508-521.

PICCOLO, A. (2001). Soil Science, v.66, p.810.

PINHEIRO, J.P.; MOTA, A.M.; GONÇALVES, M.L. (1994). Analytica Chimica Acta. v.284, p.525. 
PITOT III, H.C., DRAGAN, Y.P. (1996). Chemical carcinogenesis. In: KLAASSEN, C., Ed. Casaret \& Doll's toxicology: the basic science of poisons 5 ed. New York: Mc Graw Hill. P.201-267.

POLITO, W.L. (2002). Validação em química. São Carlos: USP.

PRADO, A.G.S.; REZENDE, M.O. (1999). Caracterização da turfa e dos ácidos húmicos das margens do Rio Mogi-Guaçu. Anais da Associação Brasileira de Química, v.48, n.4, p.186- 191.

PROSAB. (2001). Processos de desinfecção e desinfetantes alternativos na produção de água potável. Rio de Janeiro: Rima.

RADTKE, S.J.; JEPSEN, C.P. (1981). Chemical pré-treatment for activated carbon adsorption. Journal of the American Water Works association, v.73, n.8, p.411.

RIBANI, M. ET AL. (2004). Validação em métodos cromatográficos e eletroforéticos. Quimica Nova, v.27, n.5, p.771-780.

RICCA, G.; SEVERINI, F.; DI SILVESTRO, G.; YUAN, C.M.; ADANI, F. (2000). Derivatization and structural studies by spectroscopic methods of humic acids from leonardite. Geoderma, v.98, p.115- 125.

RICHARDSON, S. D.; SIMMONS, J. E.; RICE, A. G.(2002). Enviromenmental science \& Technology, v.36, n.9, p.199.

RICHTER, C.A., AZEVEDO NETTO, J.M. (1991). Tratamento de água. São Paulo: Edgard Blucher.

RIOS, E. (2004). Influência das estruturas na formação de subprodutos clorados decorrentes do uso de pré-oxidantes em tratamento de água. 77p. Dissertação (Mestrado). Instituto de Química de São Carlos, Universidade de São Paulo, São Carlos.

RITTMAN, D. (1997). "Can you have cake and eat it too" with chorine dioxide? Water/Enginering ce Management, v.4, p.30-35.

ROCHA, J.C. (2003). Substâncias húmicas aquáticas: interações com espécies metálicas. São Paulo: Unesp.

ROOK, J.; EVANS, S. (1979). Removal of trihalomethane precursors from surface waters using weak base resins. Journal American Water Works Association, v.9, n.71, p.520-524.

ROSA, A. H.; ROCHA, J.C.; FURLAN, M. (2000). Substâncias húmicas de turfa: estudo dos parâmetros que influenciam no processo de extração alcalina. Química Nova, v.23, p.472-476. 
ROSSIN, A.C. (1987). Desinfecção. In: técnica de abastecimento e tratamento de água (Tratamento de Água), v.2. São Paulo: CETESB/ASCETESB.

RUOCCO JÚNIOR, J.; SUZIKI, M.; AIBA, C.J. Trihalometanos em águas para consumo humano, incidência e estudos de potencial de formação. In: CONGRESSO BRASILEIRO DE ENGENHARIA SANITÁRIA E AMBIENTAL, 11,1981, Fortaleza. Anais. Fortaleza: Associação Brasileira de Engenharia Sanitária e Ambiental - ABES, 1981. P.2-29.

SANCHES, S.M., SILVA, C.H.T., VIEIRA, E.M. (2003a). Agentes desinfetantes alternativos para o tratamento de água. Química Nova na Escola, n.17, p.8 -12, maio.

SANCHES, S.M., AMARANTE JUNIOR, O.P.de., CAMPOS, S.X.de, VIEIRA, E.M. (2003b). Formação de trihalometanos em água de abastecimento público. Anais da associação Brasileira de Química, v.52, n.2, p. 53-57.

SANCHES, S.M. et al. (2004). Estudo da formação de subprodutos clorados na etapa de pré-oxidação com dióxido de cloro. In: XXIX CONGRESO INTERAMERICANO DE INGENIERA SANITARIA Y AMBIENTAL. 2004, Puerto Rico.

SANTOS, C.L. (1988). O controle de trihalometanos (THM) nas águas de abastecimento público. 217p. Dissertação (Mestrado) - Saúde Pública, Universidade de São Paulo, São Paulo. 1988.

SARZANINI, C.; BRUZZONITI, M.C.; MENTASI, E. (1999). Preconcentracion and separation of haloacetic acids by ion chromatographic. Journal of chromatography A, v.850, p.197.

SCHINITZER, M., KHAN, S.U. (1972). Humic substances environment. New York: Marcel Dekker.

SCHINITZER, M., KHAN, S.U. (1978). Soil organic matter In: The interaction of organic matter with pesticides. New York, Elsevier, p.136-171.

SCHINITZER, M. (1991). Soil organic matter. The next 75 years. Soil Science, v.151, p.41-48.

SCHULTEN, H.R.; SCHINITZER, M. (1993). A state of the art structural concept for humic substances. Naturwissenschaften, v.80, p.29-30.

SCHULTEN, H. R., SCHNITZER, M. (1997). Chemical model structures for soil organic matter and soils. Soil Science, v.162, n.2, p.115-130.

SCOTT, D. T., McKNIGHT, D. M., BLUNT-HARRIS, E. I., KOLESAR, S. E.; LOVLEY, D.R. (1998). Quinone moieties act as electron acceptors in the reduction of humic substances by humic-reducing microorganisms. Environmental Science and Technology. v.32, p.2984- 2989. 
SEIN JUNIOR, L.T., VARNUM, J.M.; JANSEN, S. A. (1999). Conformation modeling of a new building block of humic acid: aproaches to the lowest enegy conformer. Environmental Science Technology, v.33, p.546-552.

SENESI, N. (1990). Molecular and quantitative aspects of the chemistry of fulvic acids and its interactions with metal ions and organic chemicals. Part II. The fluorescence spectroscopy approach. Analytica Chimica Acta, v.232, n.51, p.77106.

SENEZER, N.; RIZZI, F. R.; DELliNO, P.; ACQUAFREDDA, T. (1996). Soil Science, Society American Journal, v.60, p.1773.

SHULTEN, H.R.; LEINWEBER, P.; SCHNITZER, M. (1998). Analytical pyrolysis and computer modeling of humic and soil particles. New York: Wiley.

SHULTEN, H. R.; LEINWEBER, P. (2000). Biological Fertil Soils, v.30, p.399.

SILVERSTEIN, R.M.; BASSLER, G.C.; MORRILL, T.C. (1994). Identificação espectrometrica de compostos orgânicos. Editora Guanabara Koogan, S.A John Willey \& Sons. P.23-56.

SINGER, L.S. (1959). Synthetic ruby as a secondary standard for the measurement of intensities in electron paramagnetic resonance. Journal Applied physical, v.30, p.1463- 1464.

Standards Methods for the examination of water and wastewater (1998). 20 ed. New York, APHA, AWWA, AWWA, AWPCF. CD ROM.

STEVENS, A. A.; SLOCUM, C.J.; SEEGER, D. R., ROBECK, G.G. (1976). Clorination of organics in drinking water. Journal american Water Works Association, n.68, p.615-620.

STEVENS, A. A., MOORE, L.A., MILTNER, R. J. (1997). Formation and control of non trihalomethane disinfection by-products. Journal American Water Works Association, v.89, p.5-100.

STEVENSON, F. J. (1982). Extraction, fractionation and general chemical composition of soil organic matter. In: Humus Chemistry. New York, John:Wiley \& Sons p.23-56.

STEVENSON, F. J. (1994). Humus chemistry: genesis, composition. reactions. New York, John Wiley, 496p.

SUMMERS, R. S.; CORNEL, P.K.; ROBERTS, P.V. (1987). Molecular distribution and spectroscopy characterization of humic substances. Sci. Total Environ., v.62, p.27- 37.

SUSZCZYNSKI, F.E. (1982). Turfa - O novo combustivel nacional. Energia Fontes Alternativas, v.20, n.6, p.605-608. 
SYMONS, J.M. (1976). Interim treatment guide for the control of chloroform and other trihalomethanes. Cincinnati, Office of Research and Development, 49p.

SYMONS, J.M., STEVENS, A.A., CLARK, R.M. (1981). Treatment techniques for controlling trihalomethanes in drinking water. Ohio, USA, EPA. 289p.

SWIFT, R.S. (1996). Organic matter characterization. In: SPARKS, D.L. Methods of soil analysis: chemical methods. Maddison: SSSA. P.1011-1069.

TANFORD, C. (1980). The hydrophobic effect: formation of micelles and biological membranes. New York: Wiley.

TOMINAGA, M.Y. (1988). Trihalometano em água de abastecimento: validação e correlação de dois métodos de análise por cromatografia em fase gasosa. 92p. Dissertação (Mestrado). Faculdade de Ciências Farmacêuticas da USP, Universidade de São Paulo, São Paulo.

VAUGHAN, D.; ORD, B. G. (1985). Soil organic matter and biological activity. v.16, p.34.

VIEIRA, E.M. (1996). Estudo da adsorção do herbicida 2,4D no solo e nas substâncias húmicas. 111p. Tese (Doutorado). Instituto de Química de São Carlos, Universidade de São Paulo, São Carlos.

VOLKOFF, B.; CERRI, C.C. (1988). Pédologie, v.24, p.83.

WAKSMAN, S. A. (1938). Humus: Origin, chemical compositions, and importance in nature. Balmonte: Williams \& Williams.

WERSHAW, L.R. (1986). A new model for humic materials and their inteactions with hydrophobic organic chemicals in soil-water or sediment-water systems. Journal of Contaminant. Hydrology, v.1, p.29-45.

WERSHAW, L.R. (1993). Model for humus in soil and sediments. Environmental Science \& Technolology, v.27, n.5, p.814-816.

WHITEAD, D.C.; TINSLEY. (1967). Journal Soil Science, v.97, p.34.

WOOD, R. (1999). How to validate analytical methods. Trends analysis Chemical, v. 18,p.624-632.

WORLD HEALTH ORGANIZATION (1993). Guidelines for drinking water quality. 2.ed. Geneva: WHO, v.2, p.849-872. 